\title{
NEWYYSBKHOOL
}

digitalcommons.nyls.edu

Faculty Scholarship

Articles \& Chapters

1987

\section{Dialects and Dominance: A Study of Rhetorical Fields In the Law of Confessions}

Richard K. Sherwin

New York Law School

Follow this and additional works at: http://digitalcommons.nyls.edu/fac_articles_chapters

\section{Recommended Citation}

136 U. Pa. L. Rev. 729 (1987-1988)

This Article is brought to you for free and open access by the Faculty Scholarship at DigitalCommons@NYLS. It has been accepted for inclusion in Articles \& Chapters by an authorized administrator of DigitalCommons@NYLS. 


\title{
DIALECTS AND DOMINANCE: A STUDY OF RHETORICAL FIELDS IN THE LAW OF GONFESSIONS
}

\author{
RICHARD K. SHERWIN $\dagger$
}

Table of Contents

InTRODUCTION $\ldots \ldots \ldots \ldots \ldots \ldots \ldots \ldots \ldots . \quad 730$

I. A Typology of Griminal Procedure Dialects .. 735

A. Brute Facts and Manifest Wrongs: The Dialect of Common Sense ..................... 737

B. Practical Wisdom: The Dialect of Prudent Interpretation ..........................

C. Comprehensive Modeling: The Dialect of Scientific Policymaking .......................

II. The Typology Applied: Confessions and Silence

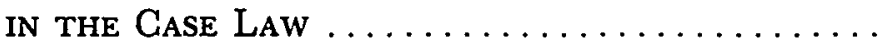

A. Common Sense and Manifest Criminality: Criminal Process as the Search for Truth ..........

B. Judicial Intuitions of Fairness: The Rise of Due Process......................... 756

C. Prudent Interpretation and the Authority of Inherited Texts: Criminal Process as the Search for Meanings.........................

D. Scientific Policymaking and the Utilitarian Cost/ Benefit Calculus: Criminal Process as Crime Control Ideology ........................

III. Dialogic Competencies: Cross-Dialectic ReciPROCITY AND THE INSTITUTION OF INTRAJUdICIAL Checks and Balances . . . . . . . . . . . . . . . . . 824

ConCLUSION $\ldots \ldots \ldots \ldots \ldots \ldots \ldots \ldots \ldots \ldots, 848$

+ Senior Instructor in Law and Co-Coordinator of the Lawyering Program, New York University School of Law. B.A. 1975, Brandeis University; J.D. 1981, Boston College Law School; L.L.M. 1986, Columbia University Law School; J.S.D candidate Columbia University Law School.

I wish to thank Bruce Ackerman, Andre Rapaczynski, and Richard Uviller for their careful and penetrating comments upon an earlier draft of this work. Errors that remain are not for want of their efforts to have me do better. I also wish to thank Casey Tegreene for his helpful research assistance. 
Every language and every well-knit technical sublanguage incorporates certain points of view and certain patterned resistances to widely divergent points of view.

\section{-Benjamin Lee Whorf*}

To conceive of the law as a rhetorical and social system, a way in which we use an inherited language to talk to each other and to maintain a community, suggests in a new way that the heart of the law is what we always knew it was: the open hearing in which one point of view, one construction of language and reality, is tested against another.

- James B. White**

Hear my words, $O$ ye wise men; and give ear unto me, ye that have knowledge. For the ear trieth words, as the mouth tasteth meat. Let us. choose to us judgment: let us know among ourselves what is good.

-Old Testament***

\section{INTRODUCTION}

Inequality mocks discourse. The absolute sovereign, assured that power will back up her every word, ${ }^{1}$ needs but to speak. She needn't listen. As for the subject, silence is her fare. Hers is but to obey. Yet, inequality is a fact of life even where tyrants do not rule. The unequal distribution of natural talents and social opportunities continues to differentiate one individual from another, regardless of whether liberal or Marxist principles prevail. Does this inequality mean that discourse proceeds within multiple kingdoms of discrete and exclusive commonal-

* B. Whorf, Language, Thought and Reality 247 (1956).

** J. White, When Words Lose Their Meaning 273 (1984).

*** Job 34:2-3 (emphasis omitted).

1 There is a subtle interplay between law and the raw power to command. See J. Austin, The Province of Jurisprudence Determined 5 (2d ed. 1861) ("Now since the term command comprises the term law, the first is the simpler as well as the larger of the two .... If you express or intimate a wish that I shall do or forbear from some act, and if you will visit me with an evil in case I comply not with your wish, the expression or intimation of your wish is a command."); see also H. HART, THE CONCEPT OF LAW 6 (1961) ("To some it has seemed clear that . . . where one person gives another an order backed by threats, and ... obliges him to comply, we have the essence of law, or at least 'the key to the science of jurisprudence'. (quoting J. Austin, supra, at 5)). 
ities? Is this the pluralist vision: a cacophony of separate communities, each with its own shared experience, vision and language-a world in which experts speak to experts and lay publics to lay publics? Is it a world in which each group remains an anomaly to the rest, each lacking the discursive power to make sense to, much less persuade, those their communal voice excludes?

Has our society been reduced to babel $?^{2}$ And what if the authorized language of power in society is spoken only by a few? Must the dominant dialogic community listen? Must those who speak in a different voice be disenfranchised by an officially imposed silence? The thesis of this Article is that in law, the distribution of power proceeds from authorized modes of discourse. The stories lawyers and judges tell, and the meanings and judgments their stories allow, "make more sense" when examined from a particular dialogic perspective. ${ }^{3}$ This means that facts, which appear "relevant" in a particular case, as well as "values," which engage a decisionmaker's belief, do so on the basis of often undisclosed (either unrecognized or concealed) assumptions about human nature or the way social institutions function. Such assumptions are often embedded within the type of discourse that the decisionmaker employs. ${ }^{4}$ This Article argues that a court's discourse should be as-

2 See N. Goodman, Ways of Worldmaking 7 (1978) ("With false hope of a firm foundation gone, with the world displaced by worlds that are but versions, with substance dissolved into function, and with the given acknowledged as taken, we face the questions how worlds are made, tested, and known.").

${ }^{3}$ Cf. P. Ricoeur, The Rule of Metaphor 261 (1981) (" "L]inguistic form is not only the condition for transmissibility, but first of all the condition for the realization of thought." " (citation omitted)).

4 See J. White, When Words Lose Their Meaning 273 (1984) ("Law works by a process of argument that places one version of events against another and creates a tension between them (and between the endings appropriate to each); in doing so it makes our choice of language conscious rather than habitual and creates a moment at which controlled change of language and culture becomes possible.").

The subject matter of this Article may be described as falling within the domain of "Rhetoric." By Rhetoric, however, I do not mean the denigrated form of empty argumentation, or persuasion for its own sake, a meaning the term has acquired since the cultural ascendancy of Descartes's objectivistic epistemology. See G. PERELman, The New RhETORIC 1-10 (1969) (opposing the Cartesian method of reasoning which relies upon apodictic, or "self-evident," truth as a model for constructing a science); D. VERENE, Vico's Science of Imagination 202 (1981) ("For Descartes, "those who have the strongest power of reasoning, and who most skillfully arrange their thoughts in order to render them clear and intelligible, have the best power of persuasion even if they can but speak the language of Lower Brittany and have never learned Rhetoric.' Truth has no need of eloquence or rhetoric, and all the arts and activities of the mind that involve them can be replaced or superseded by a single piece of clear reasoning."); see also P. FRANCE, RheTORIC AND TRUTH IN France 1-33 (1972) (tracing the rise and fall of Rhetoric in the french academy from the ancien regime to the turn of the twentieth century when Rhetoric was dropped from the school curriculum). France shows that despite Descartes's strong opposition to Rhetoric, his writings remain deeply rhetorical. Id. at 67 ("[Descartes's] is the persuasion of the philosopher who knows 
sessed in light of the particular dialect that it privileges and the way in which such official sanction is given. For example, even common sense can be used as a strategy of formal dominance, that is, as a disguised endorsement of a preferred, putatively "self-evident" social policy or foundational principle, or to mask a particular textual interpretation of a case or statute or constitution. On the other hand, common sense can be offered in its own right, as evidence of "incontrovertible" truth. The choice of approach tells us much about the meaning and goal of the decision in question. In short, this Article suggests a method for reading, or decoding, legal arguments and judicial decisions, for assessing legitimate and illegitimate uses of legal dialects, and for discovering nuances and changes within the confines of a particular dialect. ${ }^{5}$ In the law of confessions, there are three discrete dialects, three different ways of thinking and talking about self, others, and social institutions. Moreover, each of these dialects has enjoyed at least some degree of dominance over the others at different points in history. As a result, the language of power in this field has shifted from one dialogic community ${ }^{\mathfrak{B}}$ to another.

when to put forward his ideas plainly and unemotionally and when to appeal to the irrational side of human nature.").

Following White, Rhetoric should be viewed as a vibrant and rich field, particularly for legal practitioners and scholars. See J. WHITE, supra, at xi (describing Rhetoric as "the study of the ways in which character and community-and motive, value, reason, social structure, everything, in short, that makes a culture-are defined and made real in performances of language"); E. GRASSI, RHETORIC AS PHILOSOPHY 20 (1980) (stating that Rhetoric may be understood as the "basis of . . rational thought"); M. MoOney, Vico in The Tradition of Rhetoric 10 (1985) ("Eloquence without knowledge is hollow and empty; but knowledge without eloquence is mute and powerless, incapable of effect in men's lives."). According to Grassi, language proceeds not as calculus, but rather as dialogue, as speech that "breaks out" in the "urgency of the particular human situation" and begins to form a specifically human order in the confrontation with other human beings. E. GRASSI, supra, at 113.

See generally W. Booth, MOdern Dogma AND The RHETORIC OF Assent 99 (1974) ("TT]here are many logics, and . . . each of the domains of the mind (or person) has its own kind of knowing."); H. GADAMER, TRUTH AND METHOD xv (1975) ("It is a new critical consciousness that now has to accompany all responsible philosophizing and which takes the linguistic and thinking habits built up in the individual in his communication with his environment and places them before the forum of the historical tradition to which we all belong."); J. HABERMas, Communication and THE Evolution of Society 4 (1979) ("Vindication means that the proponent, whether through appeal to intuitions and experiences or through argumentation and action consequences, grounds the claim's worthiness to be recognized . . . and brings about a suprasubjective recognition of its validity.").

s According to this analysis, the totalizing subjectivity of common sense (based on conflicting, "self-evident" premises) and of particular comprehensive models (based on self-consistent, "self-evident" premises) may play a significant role in delegitimating the judicial decisionmaking process.

" A "dialogic community" is constituted by those who speak a shared language or, more specifically, a shared dialect within a common language. 
The goal of this Article is to encourage recognition of this discursive phenomenon so as to bring greater clarity to this controversial area of the law. By the same token, the dangers of dialogic dominance must be discerned and avoided. Realization of these objectives requires recognition of the significant role that discrete dialects play in the judicial decisionmaking process. Only then can one understand the need for an explicit dialogic choice. Only then, moreover, may the reader assess the utility of the criteria for dialogic choosing and the structural principle of legitimacy proposed.

This Article locates those historic junctures in the law of confessions when discursive conflicts bred fundamental, though perhaps unrecognized, misunderstandings. ${ }^{7}$ By way of what may be called a phenomenology of rhetorical fields this Article examines whether, and if so, how, misunderstandings among discrete dialogic communities are resolved. In this context, misunderstanding plays one of two possible roles. Either it cuts off discourse in the service of a dominant dialect, and thus excludes other ways of thinking and talking about the law, or it spurs the parties concerned to reach across incommensurate rhetorical fields in order to achieve some form of mutual understanding and accommodation.

The first approach, dialogic dominance, uses law talk as a means of disguising specific normative commitments. By this method, one dialect strives to disempower others while strengthening its own potency. In law, exclusive dependence upon a single form of discourse, for reasons discussed later, raises serious questions about the continued legitimacy of the judicial decisionmaking process. These questions are pertinent to the ideology of crime control, with its pervasive cost/benefit analysis. Geared to swift and sure punishment for the sake of effective deterrence, crime control is today an increasingly influential version of the dialect described in this Article as Scientific Policymaking ("SP").

By contrast, the second approach, using misunderstanding as a spur to cross-dialectic discourse and accommodation, counters the threat of dialogic dominance by encouraging reciprocal discourse among those who speak from divergent rhetorical fields. The dialect that this Article

II should be noted that while broad historical changes in the law of confessions may be correlated to significant shifts in dialogic dominance, that is, in the way jurists at the time generally thought and spoke about the law, this does not mean that nondominant legal dialects did not have a significant role to play in that area of the law. Nor does it mean that they remained nondominant during the same historical period in other areas of the law. Indeed, conflicting dialects may be at work, to varying degrees of self-reflectiveness, within the same judicial opinion. In short, the aim of this Article is not to diminish the complexity of judicial discourse, but rather to foster appreciation of its richness. 
refers to as Prudent Interpretation ("PI") serves as a point of departure for this approach. PI proceeds on the basis of contextualized applications of specific textual interpretations and procedures. It too, however, has its own tyrannical tendencies, and, like the other dialects of criminal procedure, left unchecked, its virtues are apt to be subverted by its defects. Thus Prudent Interpretation also raises the spectre of decisional illegitimacy.

An effective antidote to tyranny in the law of confessions is the institution of intrajudicial checks and balances among the discrete dialects of criminal procedure. The first step toward implementing this curative institution requires self-reflective consideration of the unique virtues and defects of each dialect. Such consideration reveals, on the one hand, a way of maximizing the virtues of each dialect and of broadening cross-dialogical discourse, while, on the other hand, it minimizes dialogical defects and rules by naked power alone. More concretely, recognizing the discrete virtues and defects inherent in the different ways of thinking and talking about a defendant's confession or silence after arrest can enhance our understanding of this conflict-ridden area of the law. At the same time, such recognition could affirm or even champion the special role each dialect and its corresponding dialogic community has to play in the criminal process. In this respect, understanding among legal experts and lay persons alike is not simply a noble aspiration. It is essential to the continued legitimacy of judicial decisionmaking in this, and perhaps other, areas of the law.

Consequently, one can view pluralism not as a cacophony of conflicting self-interested voices, each committed to its own separate and exclusive tongue, but rather as a discursive practice that derives its power and legitimacy, at least in part, from its ability to nurture and sustain cross-dialect discourse. ${ }^{8}$ This view provides a framework within which every individual who believes her rights have been violated may seek redress and receive a careful and fair hearing. ${ }^{9}$ For this to occur, however, the theoretical possibility of general persuasion must remain open. Put differently, intolerance, or raw dialogic dominance, must yield to the possibilities of meaning that diverse rhetorical perspectives may persuasively establish. By keeping the possibilities of mutual understanding open, even across discrete rhetorical fields, the promise of

See generally Pluralism and Its Discontents, 12 GRITICAL INQUIRY (1986); Rooney, Who's Left Out? A Rose by Any Other Name Is Still Red; Or, the Politics of Pluralism, 12 CRITICAL INQUIRY 550, 553 (1986) ("[P]luralism's remarkable power derives in part from its ability to nurture and sustain productivity and multiplicity.").

- See B. Ackerman, Social Justice in the Liberal State 308-10 (1980). 
full and active discourse may be realized. ${ }^{10}$ This is the promise of our liberal democracy: that there is a way of being among others in which discourse mocks inequality. ${ }^{11}$ Such an approach implicates the foundational task of American legal discourse, namely, to establish equality under law for all. ${ }^{12}$

Part I presents a typology of criminal procedure dialects. This typology describes three discrete ways of thinking and talking about self, others, and social institutions. The presuppositions that inform and shape each dialect, and that account for the stories and judgments that "make sense" (or fail to) within each dialogic perspective, find their origin here. Part II describes the historic role and degree of dominance each of these dialects has played in the law of confessions. Part III assesses the difficulties encountered in the case law in terms of the discrete defects of particular criminal procedure dialects. It also devises criteria for clarifying the law through increased self-reflection concerning both the defects and the virtues of each dialect. The need to offset the defects of one dialect with the virtues of another will give rise to the institution of intrajudicial checks and balances among all three criminal procedure dialects. By virtue of this safeguard, one may counter the threat posed by dialogical dominance-the silencing of one community by another.

\section{A Typology of Criminal Procedure Dialects}

Within the law of confessions, one can discern three discrete ways of making sense of self, others, and social institutions. I call these modalities the dialects of criminal procedure. Like dialects, they embody particular ways of talking and thinking. Also like dialects, they tend to engage and affect different social groups, or dialogical communities, in

10 See R. Bernstein, Beyond Objectivism and Relativism 210 (1983) ("Power is not a fixed quantum that is distributed unevenly among human individuals. Power is created through participation . . . . [It] is essentially intersubjective and communicative; it comes into existence only in the mutual creation of a public space in between individuals.").

11 See Sherwin, Opening Hart's Concept of Law, 20 VAL. U.L. Rev. 385, 407 (1986) (within the phenomenological perspective, man shares fundamental interrelatedness with others and things around him); see also Garet, Communality and Existence: The Rights of Groups, 56 S. CAL. L. REv. 1001, 1016 (1983) (describing personhood, communality, and sociality as structures of existence).

12 See U.S. ConST. amend. XIV, $\S 1$ ("All persons born or naturalized in the United States, and subject to the jurisdiction thereof, are citizens of the United States and of the State wherein they reside. No State shall make or enforce any law which shall abridge the privileges or immunities of citizens of the United States; nor shall any State deprive any person of life, liberty, or property without due process of law, nor deny to any person within its jurisdiction the equal protection of the laws."). 
different ways. $^{13}$ Notwithstanding their singularity, however, I shall also maintain that each dialect of criminal procedure subsists within a common language, ${ }^{14}$ the language of our liberal democracy.

These discrete dialects of criminal procedure operate within a broad rhetorical field that may be divided by two axes. The vertical axis traces a field of consciousness from naive unreflection to critical self-consciousness. The horizontal axis classifies human thought from the unsystematic to the systematic. This initial division gives rise to three types of discourse: 1) unreflective and unsystematic; 2) self-reflective and unsystematic; and 3) self-reflective and systematic. ${ }^{15}$ Each of these three modes correlates to a discrete criminal procedure dialect.

1s See N. Luhmann, A Sociological Theory of Law 287 (1985) ("All communication has to start out from the separation of perspectives.").

14 See H. Gadamer, Philosophical Hermeneutics xxxi (1976) ("Worlds given in language are not mutually exclusive entities: it is the power of language that such 'mutually exclusive' worlds can merge in understanding."); see also V. TURNER, THE Ritual Process 142-43 (1969) (" "A] nation is a community to the degree that it is a community of communities. . . [ [It must] struggle into gradual coherence." " (quoting M. BUber, Paths IN UTOPIA 136-37 (1966))).

is A fourth mode-unreflective and systematic-is inherently self-contradictory. In order to apply something systematically, a modicum of self-consciousness as to the unifying theme or principle appears necessary. However, it is possible to understand rational coherence (if not systematicity) in the absence of a principle of logical contradiction. See, e.g., P. Pucci, Hesiod and the Language of Poetry $24-25$ (1977) ("Unrestricted by an Aristotelian principle forbidding contradiction, the mythical thought builds its meaning through polarities which are contiguous and which elicit meaningful correspondences."). In this context, one might explore further a mode of thinking described by some as "mythic", see, e.g., C. Levi-Strauss, The Savage Mind 15 (1966) ("[T]here are two distinct modes of scientific thought. These are certainly not a function of different stages of development of the human mind but rather of two strategic levels at which nature is accessible to scientific enquiry; one roughly adapted to that of perception and the imagination: the other at a remove from it."), or perhaps as "symbolic", see, e.g., C. JUNG, Symbols of Transformation xxv (2d ed. 1967) ("I simply had to know what unconscious or preconscious myth was forming me, from what rhizome I sprang."). Jung also distinguishes two kinds of thinking, which he calls "directed" (or linear/conceptual), "thinking in words," and "non-directed" (or non-linear/dreamlike), thinking in "trains of images" or symbols. Id. at 16-17. Others might describe this "quadrant" as the domain of the "fabulous," see, e.g., M. MOONEY, supra note 4, at 149 ("[A] fable is the essence of things transformed in human minds ..." (citation omitted)).

In addition, one might note in this context the "mythic" systems of Adam Smith and his "invisible hand" that regulates economic exchange, see R. Nozick, ANARCHY, STATE AND UTOPIA 18-22 (1974) (discussing modes of exchange in the absence of any express social contract), Hegel's suprapersonal "Idea," which he regards as the driving power of history, or Marx's secularization of the Hegelian idea into "scientific materialism" and the class struggle for possession of the state, see G. HEGEL, REASON IN History xx-xxi (R. Hartman trans. 1953) (discussing the Hegelian and Marxian approach to history); see also S. Toulmin, 1 Human UNDERSTANDING 501 (1972) (noting shifting root metaphors from Epicurus's "Necessity," to Vico's "Providence," to Hegel's "Cunning of Reason").

To pursue these matters here, however, is beyond the scope of this work. 


\section{A. Brute Facts and Manifest Wrongs: The Dialect of Common Sense}

The first dialect may be described as the rhetoric of ordinary common sense ("OCS"). In the prereflective attitude of common sense, the meanings I share with others in the routines of everyday life inform my world, my sense of self, and the way I interact with others. What I know is "self-evident"; it is "what everybody knows." We thus share a common language that supplies the terms that construct reality.

Since common sense is unself-conscious, it neither seeks, nor could it achieve, the consistent and systematic deployment of principles that characterize other ways of thinking and talking. Indeed, the exponent of common sense rarely considers that her knowledge has a conceptual basis. For common sense, reality is tangible, and ideas, concepts, and metaphors simply provide the means to describe it. ${ }^{16}$

Like other, more reflective dialects, common sense does not hesitate to totalize experience. Unlike those systematic viewpoints, however, which reason from clear and distinct fundamental principles or axioms, ${ }^{17}$ common sense is rife with inconsistency. Absent self-reflection, such inconsistencies may remain unnoticed. Yet, even if they were pointed out, an exponent of common sense might respond, "it figures," and continue as before. Such inconsistencies are simply to be expected.

One tolerates this inconsistency because common sense places no premium on universal categories or logical structures. Rather, common sense exists as part of a culture or subculture. It emerges from experience and shared meanings. Since cultural settings and imaginative accounts are numerous, the worlds in which individuals dwell are diverse, as diverse as man's narrative imagination. ${ }^{18}$

16 C. Geertz, Local. Knowledge 58 (1983). See id. at 11 ("Common sense is not a fortunate faculty, like perfect pitch; it is a special frame of mind, like piety or legalism. And like piety or legalism (or ethics or cosmology), it both differs from one place to the next and takes, nevertheless, a characteristic form."); see also P. BERGER \& T. Luckmann, The Social Construction of Reality 21 (1966) ("The reality of everyday life appears already objectified, that is, constituted by an order of objects that have been designated as objects before my appearance on the scene. The language used in everyday life continuously provides me with the necessary objectifications and posits the order within which these make sense and within which everyday life has meaning for me.").

17 The epistemological heritage that Descartes and Locke have bequeathed to us reflects a belief in "Fixed Mind gaining command over Fixed Nature by applying Fixed Principles." S. Toulmin, supra note 15, at 21 . Twentieth-century science and history have repudiated this belief in unchanging principles or fixed essences in Nature. Instead, we now encounter "a variable Man and a variable Nature." Id.; see also R. Rorty, Philosophy and the Mirror of Nature 47-61 (1979) (discussing the Cartesian view of the mind).

18 See C. GeERTz, supra note 16, at 85 (equating common sense with the stories 
The coherence of common sense is the coherence of a world among worlds. As anthropological studies have shown, the content and style of expression of common sense varies markedly from one place to another. ${ }^{19}$ Individual characteristics, such as the tone and temper of a particular natural attitude, may be described. They cannot be reduced to logical forms, nor do they give rise to the systematic deployment of fundamental principles.

In criminal procedure, the dialect of ordinary common sense presupposes two "self-evident" truths. First, everyone knows how to assess an individual's behavior. Second, everyone knows when to blame someone for doing wrong. ${ }^{20}$ These "objective" truths describe two categories: brute facts, on the one hand, and manifest criminality, on the other. Put simply, OCS tells me that I, like every other reasonable person, am equipped with all the analytical and judgmental faculties that I need to understand the nature, meaning, and morality of a particular act.

Within the framework of OCS, the criminal process proceeds as a "search for truth," a public drama in which reliable facts are sought in order to establish the guilt or innocence of the accused. When it works, OCS satisfies ordinary expectations about blameworthiness. When it fails, however, as when the factually guilty go free due to some legal "technicality," the system seems to go awry.

There are virtues to this way of thinking and talking about the criminal process, but there are also drawbacks. ${ }^{21}$ Nevertheless, the place of this dialect in our system of criminal justice, especially with respect to the role of the jury, will require particular attention. I will

one tells about the real); White, Heracles' Bow: Persuasion and Community in Sophocles' Philoctetes, in Heracles' Bow: Essays on the Rhetoric and Poetics of THE LAW 3, 25 (1985) [hereinafter HeRacles' Bow] (noting the greater clarity, force, and persuasiveness of dramatic narrative measured against theoretical argument).

19 See C. GeERTZ, supra note 16, at 11 ("anthropological literature . . . display[s] the variation" of common sense expression); cf. B. WhORF, Language, Thought AND REALITY 162 (1956) ("different languages differently 'segment' the same situation or experience").

${ }^{20}$ See, e.g., G. Fletcher, Rethinking Criminal LAw 115-22 (1978) (arguing that the critical feature of common law larceny is that the crime be objectively discernible (that one look like a thief) at the time that it occurs); see also $5 \mathrm{~J}$. BenTHAM, Rationale of JUdicial Evidence 209 (1827) ("From the known principles of human nature, according to a course of observation common to all mankind . . . between delinquency on the one hand, and silence under inquiry on the other, there is a manifest connexion; a connexion too natural not to be constant and inseparable."); L. SPOONER, AN ESSAY ON THE TRIAL BY JURY 186 (1852), reprinted in LET's ABOLISH GOVERNMENT (1972) ("[T]hose acts which are understood by mankind at large to be intrinsically criminal should be punished as crimes.").

${ }^{21}$ For example, the inconsistencies of common sense will figure later on in this Article as the chief target of those conceptually minded jurists who decry the "inefficiency" and "muddling" that it promotes. See infra notes 53-54 and accompanying text. 
argue that the privileged status we assign expertise and the participation by various dialogical communities in the judicial decisionmaking process are concerns that merge together when our attitude towards common sense is questioned.

\section{B. Practical Wisdom: The Dialect of Prudent Interpretation}

The second dialect corresponds to what may be called "practical wisdom."22 Like common sense, practical wisdom is not, nor does it seek to be, systematic. Unlike OCS, however, it is not unreflective. Indeed, once critical reflection is introduced, the "objective" truths of uncritical common sense appear naive. Practical wisdom says that there is more to reality than what our experience "naturally" and immediately communicates to us. The "more" stems from self-reflection itself. Practical wisdom begins by questioning what it knows. Upon reflection, it is not the world, or life, or reason itself that makes common sense, or even logic, what it is. Rather, it is the discrete and specifically analyzable ways in which particular individuals or groups, in specific contexts and at a given time, organize their life experiences in meaningful ways. The meanings in question are those the actors themselves share. ${ }^{23}$ In short, practical wisdom tells us that there is a structure, a characteristic pattern, which informs specifically enculturated expressions of common

${ }^{22}$ This term is a translation of the Greek term, "phronesis." Gadamer translates phronesis as "the virtue of thoughtful reflection." H. GADAMER, supra note 4, at 288; see also Aristotle, Nicomachean Ethics, in Introduction to ARISTotle 300, 431 ( $R$. McKeon trans. 1947) ("Practical wisdom . . . is concerned with things human and things about which it is possible to deliberate; for we say this is above all the work of the man of practical wisdom, to deliberate well, but no one deliberates about things invariable, nor about things which have not an end, and that a good can be brought about by action.").

On this view, deliberation may be considered more akin to an "art," whereby the interpreter plots a particular narrative, than to a "science," whereby impersonal truths generate objective and universalistic propositions. See M. MoONEY, supra note 4, at 117 (noting that to be "publically effective" requires flexibility, adaptability and concreteness and that this often requires circuitous means to proper ends). For Vico, Mooney says that such effectiveness "required . . . less a training in science" than one of "prudence." Id. The epistemological uncertainty surrounding artistic endeavors, as viewed from the scientific perspective, accounts for the tension that exists between the human and the natural sciences-a tension that the dialects of Prudent Interpretation and Scientific Policymaking also reflect. See generally G. vON WRIGHT, ExPLANATION AND UNDFRSTANDING 4-7 (1971) (linking natural science to explanation and prediction, and human science to empathic understanding). For the PI/SP analogue to this notion, compare text accompanying infra notes 36-41 with text accompanying infra notes 26-28.

${ }^{23}$ See C. Geertz, The Interpretation of Cultures 14 (1973) ("[C]ulture is not a power, something to which social events, behaviors, institutions, or processes can be causally attributed; it is a context, something within which they can be intelligibly ... described."). 
sense. The multivocal or complex (polysemous) aspect of local frames of awareness becomes a part of what we know. ${ }^{24}$

With increased self-reflection, then, one may trace particular presuppositions or perspectives to particular contexts-to histories, inherited texts, and local experiences. The faculty of critical interpretation thus becomes an essential guide to understanding contextualized meanings. $^{25}$

Interpretive sense seeks to pierce the matter-of-fact reality that common sense naively embraces. It strives to decode, in order to make sense of, specific patterns of behavior, including principled, unprincipled, and symbolic forms of communication. Interpretation, as it comes to reflect the meaning of everyday life, tells us how accounts of the real are being constructed. It embodies a search for meaning that focuses upon existing structures and events. It seeks not to superimpose abstract formulations, but rather to unfold local meanings. ${ }^{26}$

Practical wisdom reveals that common sense is as much an interpretation of the immediacies of experience as myth-making, painting, or epistemology. Like them, it too is historically constructed and subject to historically defined standards of judgment. Moreover, since interpretive sense also is historically situated, it is no less "fashioned" than the events or ongoing patterns of life it seeks to understand. From this perspective, the proper aspiration of practical wisdom is to do justice to what it seeks to describe and understand. ${ }^{27}$ In this sense, there are no independent or invariant principles of order guaranteeing the authority of a given interpretation. There are only attempts to explain and justify particular understandings, to give plausible and persuasive reasons in their behalf. The way I interpret experience engages my own and others' historic presuppositions. These are but "interpretations" that require critical reflection, or reinterpretation, in the present context.

24 See C. Geertz, supra note 16, at 6; see also P. Berger \& T. Luckmann, supra note 16, at 39 ("Language provides me with a ready-made possibility for the ongoing objectification of my unfolding experience. . . Put simply, through language an entire world can be actualized at any moment.").

2b This brings us to a critical insight in philosophical hermeneutics. See $\mathbf{H}$. GADAMER, supra note 4, at 294 ("It is the work of interpretation to make the law concrete in each specific case, ie[sic] it is a work of application."); see also $\mathrm{H}$. Gadamer, Practical Philosophy as a Model of the Human Sciences, in Research in Phenomenology 74, 83 (1979) ("This is hermeneutics: to let what seems to be far and alienated speak again.").

${ }^{26}$ See C. GEERTZ, supra note 16, at 5 ("I do not believe that what 'hermeneutics' needs is to be reified into a para-science . . . and there are enough general principles in the world already.").

${ }^{27}$ See id. at 76; see also R. BERNSTEIN, supra note 10, at 154 (noting "Aristotle's assertion . . . that the appropriate form of knowledge and reasoning is conditioned by the subject matter"). 
Because what I know is uncertain, how best to narrate and assess particular events cannot be known for sure before I encounter the particular drama in question. ${ }^{28}$ Thus, to the extent that historical knowledge shapes and informs what I know, I must critically encounter that knowledge continuously within shifting contexts that elicit my interpretive faculty. To the extent that meanings are unclear except in a given context, traditions are always being reconstrued, and while some are being revitalized, others are being superceded. From the perspective of unsystematic self-reflection, meanings are the product of a current encounter with specific events and texts in particular contexts. As the latter shift, so too do the former. In this way, the emergence of meaning is an ongoing event. It is the offspring of a dialectic involving events, narrative possibilities, and the critical assessment of one proffered account as opposed to another.

Given the endless variations of events as context, the unavailability of interpretative certainty-in advance of any critical encounter with contextualized meanings-may not seem surprising, nor should the tendency of practical wisdom to question what it knows. This is what is meant when one says that self-reflection itself drives the search for meaning.

In the criminal process, the dialect that I call Prudent Interpretation accounts not only for jurists' traditional commitment to stare decisis, the textually collected wisdom of the legal culture, but also for the constant (re)interpretation of inherited texts within the flux of concrete, historic contexts. In this sense, PI may be said to embody a special type of expertise. Lawyers acquire this expertise through technical training and practical experience. ${ }^{2 \theta}$ By virtue of their education and practice, lawyers grow familiar with the repository of legal topics textually interpreted through generations of case law, and a repertoire of interpretive techniques by which the meanings of precedents are narrowed, broadened or abandoned. ${ }^{30}$

We may think of this dialect as "prudent" in that it is guided by the particular needs and aspirations of the parties before the court, the court's own need to inspire compliance by the parties concerned, as well as others who might be affected by the court's ruling, and the

${ }^{28}$ See H. GADAMER, supra note 4, at 250 ("[W]e stand always within tradition. ... Even the most genuine and solid tradition . . . needs to be affirmed, embraced, cultivated.").

${ }^{20}$ As Lord Coke said in 1612, the lawyer's is not everyman's "natural reason," but rather "an art which requires long study and experience." $1 \mathrm{~J}$. CAMPBELL, THE Lives of THE CHIEF Justices of ENGLAND 272 (1849).

so See generally $\mathrm{K}$. Llewellyn, The Common Law Tradition: Deciding APPEALS 62-120 (1960) (discussing the interpretation and application of precedent). 
court's duty to comply with the demands of relevant texts, such as cases, statutes, and constitutions. ${ }^{31}$ The dialect of PI is "interpretive" in that it perceives no standpoint outside of the particular, contextualized meanings of texts and events that particular controversies involve. In other words, there are no impersonal principles or axioms, no self-consistent set of comprehensive principles, that can vouchsafe a particular interpretation. $^{32}$ The court's compliance with the meaning of a given text, therefore, must take into account not only past interpretations, but also the constant demand for current (re)interpretation. Its prudence, then, is the product of this dialectic between shifting events and the critical, contextualized interpretations of the legal topics that they involve, on the one hand, and strategic concerns, such as public and official compliance, on the other. There are distinct virtues to thinking and talking about the criminal process in this way, and there are also distinct drawbacks. ${ }^{33}$ Before exploring these matters further, let us turn to the third dialect of criminal procedure. Unlike ordinary common sense and practical wisdom, this dialect combines both self-reflectiveness and

31 Cf. Kronman, Alexander Bickel's Philosophy of Prudence, 94 YALE L.J. 1567, 1569 (1985) ("A prudent judgment . . . takes into account the complexity of its human and institutional setting . . . A prudent person . . . is able to accept the final incommensurability between any system of ideas and the world as it is given to us with all its raggedness and inconsistency ...." The antithesis of prudence is embodied in "the impatient, uncompromising, and overly philosophical insistence on principles for their own sake.").

${ }^{32}$ Following Gadamer's position in his longstanding debate with Jürgen Habermas on this issue, while critical reflection may distance us from many historical rules and practices, and thus allow us to adapt to changing social contexts and meanings in ways that revitalize our legal tradition, we can never fully emancipate ourselves from our linguistic grounding in the legal tradition. See H. GADAMER, supra note 14, at $26-42$.

${ }^{33}$ For example, by undercutting the authority of rational concepts for the sake of contextualized interpretations, practical wisdom threatens to forgo "certainty" and "predictability"- the watchwords of justice in our legal system. See First Nat'l City Bank v. Banco Para el Comercio Exterior de Cuba, 462 U.S. 611, 621 (1983); Thor Power Tool Co. v. Commissioner, 439 U.S. 522, 549 (1979); see also W. LAFAve \& A. Scott, Griminal Law $\S 2.1(\mathrm{f}$ ) (student ed. 1986) (discussing the origins of the need for certainty in the law).

Correlatively, this dialect seems to embrace contestability and incompleteness. In this way, PI opens itself to the charge of subjectivism, relativism, and, more menacingly still, nihilism. These charges, however, are perhaps more relevant in the context of the instrumentalist, social policy-oriented Legal Realist movement. See Woodward, The Limits of Legal Realism: An Historical Perspective, in New Directions IN LEGal Education 379 (H. Packer \& T. Ehrlich eds. 1972) ("[D]oes the functional approach not teach all manner of men to look to law as an instrument for their private or personal disposal?"). Of note here as well are efforts by various members of the more recent Critical Legal Studies movement to push even further the Realists' insights concerning subjective instrumentalism in the current legal culture. See, e.g., Singer, The Player and the Cards: Nihilism and Legal Theory, 94 YALE L.J. 1, 5 (1984) ("The issues raised by the Critical Legal Studies movement have brought nihilism to center stage."). 
systematicity.

\section{Comprehensive Modeling: The Dialect of Scientific Policymaking}

The dialect of Scientific Policymaking is both self-reflective and systematic. Like common sense, this dialect is confident about what it knows. Unlike common sense, however, it is also confident that it can deploy what it knows systematically across a broad spectrum of experiences and events. According to Ackerman, this way of thinking and talking is "scientific" in the sense that its language is esoteric; it follows technical, stipulated meanings that set it apart at the outset from ordinary, everyday speech. ${ }^{34}$ It is a form of policymaking in that its definitions form a core of relatively few general principles or fundamental insights. These fundamentals serve as basic axioms, or root metaphors, which describe the purposes or abstract values that the legal system presumably furthers. Ackerman refers to this set of core beliefs as a "Comprehensive View."35

In the current legal culture, one can identify two discrete comprehensive views that make up the dialect of Scientific Policymaking. ${ }^{36}$ To oversimplify somewhat, one view focuses upon rights or duties, while the second focuses on maximizing interests. The former view has been associated with the philosophy of Kant and, more recently, with the writings of John Rawls. ${ }^{37}$ The latter has been associated with the utili-

34 See Ackerman, Four Questions for Legal Theory, in PROPERTY: Nomos XXII 354 (J. Pennock \& J. Chapman eds. 1980) ("IA] stream of legal discourse [is] Scientific when it contains 'a set of technical concepts whose meanings are set in relation to one another by clear definitions without continuing reliance upon the way similar sounding concepts are deployed in nonlegal talk'." (quoting B. ACKerman, Private Property AND THE Constitution 10-11 (1977))).

${ }^{35}$ B. ACKERMAN, supra note 34, at 11; see, e.g., Ackerman, supra note 34, at 355 ("In a Policymaking argument, the claimant justifies his position by linking it to a Comprehensive View said to embody the ideals governing the legal system."). For example, utilitarianism may be said to embody a comprehensive viewpoint that is built upon a single principle of great abstraction and generality (e.g., that society ought to be arranged so as to maximize its citizens' aggregate utility).

${ }^{36}$ See, e.g., Friedman, Two Faces of Law, 1984 WIS. L. REv. 13, 32-33 (arguing that both rights and interests theories are aspects of legal culture, as well as tools of scholarly analysis); Damaska, Evidentiary Barriers to Conviction and Two Models of Criminal Procedure: A Comparative Study, 121 U. PA. L. Rev. 506, 579 (1973) (noting the conflict in criminal procedure "between efficient pursuit of the truth and protection of values such as human dignity and privacy"); Michelman, Political Markets and Community Self-Determination: Competing Judicial Models of Local Government Legitimacy, 53 IND. L.J. 145, 148-57 (1977-78) (suggesting the "coexistence" of economic and noneconomic models of local government legitimacy).

37 See C. Fried, Right and Wrong 197-98 (1978) (linking Rawls' contractarian theory of justice to Kantian ideas); Fletcher, Why Kant, 87 Colum. L. REv. 421, 428-30 (1987) (describing how Rawls draws upon Kant's conceptual model of social cooperation, and outlining Kant's fundamental principles of right, law, and free 
tarian philosophy of Bentham and, more recently, with the law and economics movement that has centered around the University of Chicago. ${ }^{38}$ What distinguishes these two models is the source as well as the nature of the authoritative norms or axioms to which each model lays claim. Despite their fundamental differences, however, these two viewpoints share the same antipathy towards history. Indeed, each would assert its own principles' independence of a particular historical context. $^{39}$ By virtue of the antithesis of their respective claims, however, each putatively comprehensive model creates a special context for the other: the context of self-delusion.

For its part, the rights- or duty-oriented approach claims that its authority is intrinsic to reason itself. ${ }^{40}$ According to this view, right action is informed and guided by a set of rules and conditions that are based upon rational volition. These rational principles are viewed as

will). But see J. RAwLS, A Theory of Justice 11 (1971) ("[T]hose who engage in social cooperation choose together . . . the principles which are to assign basic rights and duties and to determine the division of social benefits."). Rawls' emphasis, especially in his most recent work, upon the practical aspect of justice and the need for agreement and reconciliation through "public reason" make his association with the Kantian comprehensive view seem exaggerated. See, e.g., Rawls, Justice as Fairness: Political Not Metaphysical, 14 PHIL. \& PuB. AfF. 223, 245-46 (1985) [hereinafter Rawls, Justice as Fairness] ("As found in Kant . . . these comprehensive ideals [of autonomy and individuality,] despite their very great importance in liberal thought, are extended too far when presented as the only appropriate foundation for a constitutional regime. So understood, liberalism becomes but another sectarian doctrine." (footnote omitted)); see also Rawls, The Idea of an Overlapping Consensus, 7 Oxford J. LEGAL STUD. 1, 6 (1987) [hereinafter Rawls, Overlapping Consensus] ("Given the fact of pluralism, and given that justification begins from some consensus, no general and comprehensive doctrine can assume the role of a publicly acceptable basis of political justice.").

Although Rawls recognizes in these recent writings the difficulties that attend comprehensive abstract schemes that resist historical contextualization, his contextcleansing "veil of ignorance" remains intact. See Rawls, Justice as Fairness, supra, at 235-37 (discussing the need for an original position that will "not be affected by the contingencies of the social world").

s8 See C. FRIED, supra note 37, at 86-100 (presenting an economic analysis of rights); see also R. POSNER, The ECONOMIC ANALYSIS OF LAW 11-15 (3d ed. 1986) (discussing the relevance of utility and efficiency for evaluating legal rules); Rubin, Why Is the Common Law Efficient?, 6 J. LEGAL STud. 51, 51-63 (1977) (demonstrating the efficiency of the common law in parties' tendencies to litigate inefficient rather than efficient rules).

${ }^{39}$ In other words, from within their respective comprehensive views, neither Kantian rationality nor utilitarian empiricism brooks alternative epistemological premises. In this sense, SP dialogue employing either viewpoint aspires to create an impersonal, ahistorical categorization scheme.

${ }^{10}$ Within the Kantian (or deontological) mode of rationalist thinking, one speaks more of self-evident duties than of rights. See I. KANT, FUNDAMENTAL PRINCIPLES OF the Metaphysics of Morals, in Kant's Critique of Practical Reason and OTher Works on THE Theory of ETHICs 1, 16 (T. Abbott trans. 1909) (Kant's third proposition: "Duty is the necessity of acting from respect for the law."). 
independent of history and experience. ${ }^{41}$ As Kant stated:

[A]n action done from duty derives its moral worth, not from the purpose which is to be attained by it . . . and therefore does not depend on the realization of the object of the action, but merely on the principle of volition by which the action has taken place, without regard to any object of desire. ${ }^{42}$

Every exercise of moral will makes a universal claim. Thus, given the universality of reason, an act that is deemed right for one agent "must be right for every similarly situated person." ${ }^{\prime 3}$

The Kantian comprehensive view may now be stated. It consists in treating the other as an autonomous rational agent capable of reasoned choice. Each actor may exercise her moral will in accordance with the impersonal dictates of universalizable rational principles. The rationality of morality itself derives from treating the other principally as an end rather than as a means to an end. As the well-known Kantian first principle (or "categorical imperative") dictates: "I am never to act otherwise than so that I could also will that my maxim should become a universal law." 44

41 Id. at 16, 49-51.

12 Id. at 16.

43 Golding, Principled Judicial Decision-making, 73 ETHIcs 247, 248 (1963); see also I. KANT, supra note 40 , at 48 (stating that "the ultimate condition of [the] harmony [of the will] with the universal practical reason [is that] the will of every rational being [is] a universally legislative will" (emphasis omitted)).

14 I. KANT, supra note 40, at 18 (emphasis omitted). Alternatively, Kant puts the categorical imperative in these terms: "So act as to treat humanity, whether in thine own person or in that of any other, in every case as an end withal, never as means only." Id. at 47 (emphasis omitted).

It should be noted that Kant's formulation of his categorical imperative leaves ambiguous whether not merely the normative good and just in law and politics, but also its substantive content, must be universally quantified for all persons. Among Kantian scholars, this issue involves discerning the proper relationship between the "right" and the "good." For example, a well-known (albeit refutable) criticism holds that absent any express correlation between the good in personal morality, which is grounded wholly in the categorical imperative, and the normatively good and just in law and politics, which is grounded at least in part in a posteriori factors, Kantian philosophy could be used to help legitimate such reprehensible regimes as Hitler's National Socialist government; it would pass the pivotal criterion of being generalized into universal law. See Northrop, Towards a More Comprehensive Concept of the Self, in EASTWest Studies on the Problem of the Self 1, 7 (P. Raju \& A. Castell eds. 1968); see also Weinrib, Law as a Kantian Idea of Reason, 87 Colum. L. Rev. 472, 489 (1987) ("What matters for the concept of right is not the specific object that free choice is attempting to achieve, but only that it is a free choice that attempts to achieve it. Only the form of the choice as free, not its content, comes into consideration.").

That the controversy has lost none of its passionate intensity today is evident in the recent sharp exchange between Finnis, Legal Enforcement of "Duties to Oneself": Kant v. Neo-Kantians, 87 Colum. L. Rev. 433, 433-56 (1987), and Richards, Kantian Ethics and the Harm Principle: A Reply to John Finnis, 87 Colum. L. Rev. 457, 
In this way, respect for the autonomy and dignity of individuals becomes a paramount value. Thus, the Kantian model is liberal in the classical sense. Rights are exercised in society "by compelling others to respect the choices they have made, say by entering into contracts ."45 The state may legitimately punish individuals only insofar as such punishment "compel[s] the citizenry to respect the structure of Right, the structure that guarantees to every individual the freedom to act on his private choices." ${ }^{\text {46 }}$ In other words, the Kantian (systematic) model seeks to "guarantee[] the maximum amount of private choice for each individual compatible with a like degree of choice in others."47 Consistent with this view, rights are priceless. They exist, as Friedman says, in "unlimited supply. . . . We cannot exhaust our supply of free speech. Rights are not rationed. . . . A right is a claim that must be granted, regardless of cost or supply."

In contrast to rights, interests may be assessed on the basis of relative cost or supply. For example, theorists of criminal law initially described the deterrent effect of law as the product of a simple cost/benefit calculus. Bentham gives us the primary axiom on which this system relies: "Pain and pleasure are the great springs of human action."49 According to this view, each of us engages in a rational calculation when deciding whether to violate the law. If the cost of punishment appears to outweigh the benefit of crime, individual self-interest dictates forgoing the crime. If the Kantian deontology eschews experience, passion, and individual self-interest in ascertaining rational standards for right conduct, the second systematic model starts out from completely different premises. It proceeds as a calculus of comparative utilities, or preferred interests. Thus, in lieu of the autonomous individual's rational volition, the utilitarian model focuses upon the actual consequences that particular choices produce. ${ }^{30}$ Moreover, the quotient of

457-71 (1987). For differing viewpoints on the highly controversial topic of the "right" versus the "good," see Benson, External Freedom According to Kant, 87 Colum. L. Rev. 559, $559-79$ (1987); Fletcher, Law and Morality: A Kantian Perspective, 87 Colum. L. Rev. 533, 533-58 (1987).

45 Fletcher, Human Dignity as a Constitutional Value, 22 U. W. OnTario L. REv. 171, 175 (1984).

${ }^{16} \mathrm{Id}$.

47 Id.

18 Friedman, supra note 36, at 19.

$49 \mathrm{~J}$. Bentham, Principles of Penal Law, in 1 The Works of Jeremy BenTHAM 367, 396 (J. Bowring ed. 1962).

${ }^{\text {so }}$ The type of utilitarianism described here comports with what Rawls calls the "strict classical doctrine." The central idea of this doctrine states that "society is rightly ordered, and therefore just, when its major institutions are arranged so as to achieve the greatest net balance of satisfaction summed over all the individuals belonging to it." $\mathrm{J}$. RawLS, supra note 37, at 22. 
"pleasure," or whatever preferred "self-evident" interest happens to inform the ruling utilitarian calculus, ${ }^{51}$ now provides the only reliable measure for judgment. Accordingly, in the second systematic model, the Kantian view of human nature is replaced by an entirely different picture. The rationalist's assertion that a person's "natural benevolence" may be realized by isolating duty from pleasure bows to the sovereignty of pleasure itself.

The "self-evident" truths that drive and inform the utilitarian model are observational, rather than analytical or intrinsic to reason itself, as the Kantian view holds. When the utilitarian gazes upon the world and its creatures, humans appear as particular, interest-maximizing, self-consciously calculating animals. By projecting in a systematic way this "self-evident" truth about human nature, the utilitarian model builds a comprehensive theory that assesses actions on the basis of behavioral consequences. Utilitarianism defines its preferred social policy goal as maximizing the positive (i.e., pleasure-producing, or interest-reinforcing) consequences for the greatest number of individuals. ${ }^{82}$ According to the utilitarian view, individual rights are devoid of substance. Since they lack any empirical foundation, to talk of them is to talk nonsense, and (in Bentham's immortal phrase) to talk of natural rights is simply "nonsense upon stilts." Since we must treat man as he is, says Bentham, minimizing pain and maximizing pleasure represents the best hope, and the only sensible goal, that we may seek to

B1 The range of possible preferred interests includes wealth maximization, see $R$. PosNeR, supra note 38, at 15 ("[W]ealth maximization is an important-conceivably the only effective-social instrument of utility maximization."), efficient, quality-controlled deterrence, see H. Packer, The Limits of the Criminal Sanction 164-65 (1968) ("[T]he Crime Control Model accepts the probability of mistakes up to the level at which they interfere with the goal of repressing crime .... In this view, reliability and efficiency are . . . complementary characteristics."), and love, see Griffiths, Ideology in Criminal Procedure or a Third "Model" of the Criminal Process, 79 YaLE L.J. 359, 371 (1970) ("[Packer] assumes disharmony, fundamentally irreconcilable interests, a state of war. We can start from an assumption of reconcilable-even mutually supportive-interests, a state of love."). The difficulty utilitarians have in grounding a particular interest, i.e., of curtailing the plethora of "self-evident" truths that it generates, has been the source of potent criticism. See, e.g., A. MAcINTYRE, AFTER VIRTUE 63-64 (2d ed. 1984) ("[T]he notion of human happiness is not a unitary, simple notion and cannot provide us with a criterion for making our key choices. If someone suggests to us .. . that we should guide our own choices by the prospects of our own future pleasure ... the appropriate retort is to enquire: 'But which pleasure . . . ought to guide me?" "). Kantians face a similar critique. Id. at 62, 66-67 (describing both the concept of rights and that of utility as a matching pair of incommensurable fictions).

${ }^{62}$ See J. Bentham, An Introduction to the Principles of Morals and Legislation, in 1 The Works of Jeremy Bentham, supra note 49, at $1,1$.

$63 \mathrm{~J}$. Bentham, Anarchical Fallacies, in 2 The Works of Jeremy BenTHAM, supra note 49 , at 501 ("Natural rights is simple nonsense: natural and imprescriptable rights, rhetorical nonsense,-nonsense upon stilts." (emphasis omitted)). 
realize in society. ${ }^{54}$ By this reasoning, to free the criminal for the sake of some vague abstraction (for instance, one that derives rights from universalizing rational volition) makes no sense at all. Nor does the lay person's insistence upon participating in the decisionmaking process. This would trade the efficiency of an adjudicative process run by experts, and the efficacy of deterrence that only swift and sure punishment allows, for prolonged, "unself-reflective" deliberations and unpredictable outcomes. In the utilitarian universe, where cost/benefit analyses prevail, social goals, such as crime control and deterrence, require maximum support. These are the preferred social values that the laws must maximize. ${ }^{.5}$

There are virtues in thinking and talking about the criminal process in each of the two, admittedly divergent, ways that the Kantian and utilitarian systematic models allow. As with the other criminal procedure dialects, however, there are also distinct drawbacks. ${ }^{58}$

The goal of this Article is to show how controversies in the law of confessions take shape, at least in part, as a result of particular modes

of See J. BeNTHAM, supra note 52, at 1 ("Systems which attempt to question [the principle of maximizing utility] deal in sounds instead of sense, in caprice instead of reason, in darkness instead of light.")

Bo See D. BaumgardT, Bentham and the EThics of Today 131-34 (1952). According to Baumgardt, if we were guided solely by common sense, that is, "the plausible ideas of the plain man," we would still be in the middle ages. Id. at 528 .

It should be noted that the distinction between the utilitarian and Kantian comprehensive views is not a matter of countering a consequentialist with a nonconsequentialist analysis. Some goal-oriented law talk might be concerned with maximizing individual rights. Rawls's writings, for example, might fit this description. There is, however, a compelling distinction between these two versions of Scientific Policymaking that remains. As Summers points out, a view such as Kant's is not merely rightness oriented. Its justifying reasons always turn on the accordance of a decision with applicable norms of right action. By contrast, while the utilitarian approach may account for rightness to some extent, its use of goal-oriented reasons to justify its decisions always involves a prediction of future decisional effects. See Summers, Two Types of Substantive Reasons: The Core of a Theory of Common-Law Justification, 63 CoRNELL L. REv. 707, 717-18 \& n.35 (1978).

so For example, the criteria for a preferred comprehensive view and the particular social policy that it spawns are not easily discernible. How do we determine the content of those "interests" that our social institutions are supposed to "maximize"? Is it pleasure? Or wealth? Or, alternatively, if self-interest is to yield to rational rights or duties, upon what legal sources can we rely when individual claims of right clash?

MacIntyre argues that there is no rational basis to make such a decision: "[E]very attempt to give good reasons for believing that there are such rights has failed." A. MACINTYRE, supra note 51, at 69. According to MacIntyre, "[t]he incoherence of our attitudes and our experience arises from the incoherent conceptual scheme which we have inherited." Id. at 68. Resort to intuition as a source of "self-evident" truth is similarly problematic: "[T] he introduction of the word "intuition' . . . is always a signal that something has gone badly wrong with the argument." Id. at 69 . Thus, Greenawalt's reliance upon the "objective" datum of moral intuition to assess the right to silence falls prey to the same fallacy. See Greenawalt, Silence as a Moral and Constitutional Right, 23 WM. \& MARY L. REv. 15, 18 (1981). 
of thinking and talking. In what follows, the shifting roles these dialects play in our criminal justice system will be shown. By identifying the specific controversies each dialect engenders, and examining the discrete virtues and defects of each, this Article endeavors to generate criteria for making a self-reflective dialogic choice. The question here is, how shall we think and talk about individuals and events in the criminal process? Once posed, we shall see that this question in turn raises others, such as: How shall we narrate and interpret the dramas that criminal indictments give rise to? What are the appropriate principles, or texts, or intuitions that are to inform and guide judgments about criminality?

The following chart will summarize the discrete rhetorical fields that constitute the typology of criminal procedure dialects described above:

$\begin{array}{lcl} & \text { unreflective } & \\ & + & \\ \text { (ordinary common } & + & \text { (logical } \\ \text { sense [OCS]) } & + & \text { contradiction } \\ \text { (rational/intuitive } & + & \text { ["mythic" } \\ \text { common sense) } & + & \text { modality]) } \\ & + & \end{array}$

unsystematic

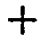

systematic

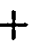

(prudent

$+$

(scientific

interpretation $[\mathrm{PI}])$

$+$

policymaking [SP])

self-reflective

II. The Typology Applied: Gonfessions and Silence in the Gase Law

A. Common Sense and Manifest Criminality: Criminal Process as the Search for Truth

As B. James George has remarked, "Confessions have been considered a primary source of information about crimes for as long as 
crimes have been committed." were "the queen of all evidence." Cens Curies later, Bentham championed confessions in similar terms. He considered them "the very best possible sort of evidence: the evidence the most completely satisfactory." ${ }^{59}$ Putting the point bluntly, he asked: "Having this, what more can you desire?"60

This view of a defendant's confession and, as we will also see, of a defendant's silence before trial, is rooted in common sense. It reflects "what everybody knows" about how people behave, and, according to Bentham, it produces trial outcomes that are based on "the known principles of human nature, according to a course of observation common to all mankind . . ." In the words of Sidney Hook, these common sense truths "can be overlooked only by a 'trained incapacity,' to use Veblen's phrase, to see the obvious in a search for the historically recondite."

The way one understands human nature seems to play a crucial, albeit unwitting, role here. For example, whether a particular defendant's confession can be explained by external pressures, such as police threats or promises, rather than by some internal compulsion to confess, has divided the courts' "common sense" judgments. ${ }^{63}$ On the one hand, to those in whose view human nature tends toward calculative selfinterest, it seems only natural to conclude, as did Justice Ruffin, that "few things happen seldomer, than that one, in the possession of his understanding, should of his own accord make a confession against himself, which is not true." ${ }^{\text {"44 }}$ On the other hand, for those who perceive the frailties of the human psyche, another logic unfolds. Such is the view expressed in the leading case of People v. McMahon. ${ }^{65}$ At

87 B. George, Constitutional Limitations of Evidence in Criminal CASES 257 (1969).

s8 Id.

s9 $5 \mathrm{~J}$. BENTHAM, supra note 20 , at 210 .

${ }^{\infty} \mathrm{Id}$.

61 Id. at 209.

62 S. Hook, Common Sense and the Fifth Amendment 14 (1957).

6s See Tuttle v. People, 33 Colo. 243, 250, 79 P. 1035, 1038 (1905) (stating that "[i]t is impossible to reconcile the various cases"); see also $3 \mathrm{~J}$. WIGMORE, Evidence IN TRIaLS AT Common LAW $\S 822$ n.l (J. Chadbourn rev. ed. 1970) (quoting J. Wigmore, Evidence in TRIals at Common Law $\$ 822$ (3d ed. 1940), which noted that "different and inconsistent practical tests" of the testimonial trustworthiness of confessions have developed "at the hands of various Courts").

64 State v. Cowan, 29 N.C. (7 Ired.) 239, 246 (1847).

os 15 N.Y. 384 (1857); see also Hendrickson v. People, 10 N.Y. *13, *33 (1854) (Seldon, J., dissenting) ("The object of the law is to ascertain truth . . . The mental disturbance produced by a direct accusation, or even a consciousness of being suspected of crime, is always great, and, in many cases incalculable. . . . [T] he moment that fear seizes the mind, the basis of all reliance upon its manifestations is gone."). In $\mathrm{McMa}$ - 
issue here was whether a defendant's sworn statement, made after his arrest for the alleged murder of his wife, could be admitted in evidence against him at a coroner's inquest. Even at this early stage in the law of confessions, voluntariness was a central concern of the court. But the meaning of voluntariness was linked to the reliability, not the volitional quality, of the statement in question (i.e., did the defendant speak the truth?). As the court stated in McMahon: "[A] confession obtained by either threats or promises, from any one having authority over the accused or concerned in the administration of justice, is uniformly held to be inadmissible. However slight the threat or small the inducement thus held out, the statement will be excluded as not voluntary." we see expressed here the widespread sentiment that there is no place in the criminal process for untrustworthy evidence. ${ }^{67}$

In McMahon, the fact of arrest alone was deemed sufficient to overcome the "spontaneity" of an accused's statements. The court reasoned that when a defendant knows he is suspected of a crime, when action has in fact been taken against him, the agitation of mind he experiences renders his statements unreliable. Taking an oath under such circumstances, while not "compulsive" in any constitutional sense, nevertheless only compounds the disturbance. The net effect renders the statement unworthy of belief and therefore inadmissible as evidence against the accused. This common sense approach won widespread support across the country. ${ }^{68}$ It reflected the belief that the mind of the

hon, Judge Seldon's opinion became the majority view. See, e.g., People v. Wentz, 37 N.Y. *303, *305 (1867) ("However slight the threat, or small the inducement thus held out, the statement will be excluded, as not voluntary."). A long line of English cases expressed the same viewpoint. See, e.g., $3 \mathrm{~W}$. Russell, A TREatise ON CRIMES AND Misdemeanors ch. $4, \S 1$, II a-g (5th ed. 1877) (discussing the relevant conditions for determining the admissibility of confessions).

${ }_{68} 15$ N.Y. at 386 (emphasis added).

${ }^{67}$ Notably, this sentiment did not preclude the use of trickery or other forms of inducement that do not jeopardize truthfulness. Nor are the courts concerned about violating a defendant's constitutional privilege against compelled self-incrimination. If obtaining a confession by violating a defendant's privilege-either by fraud, by violations of confidence, or by stratagem-yields reliable evidence, "the law will avail itself of it." Id. at 390. See Dix, Mistake, Ignorance, Expectation of Benefit, and the Modern Law of Confessions, 1975 WASH. U.L.Q. 275, 284 \& nn.23-24 (describing the tendency of American courts to depart from the stricter English rules on the admissibility of "induced" statements). Put simply, the question is "whether the evidence can be relied upon, and not how it was obtained." McMahon, 15 N.Y. at 391; see People v. Castree, 311 Ill. 392 , 396-97, 143 N.E. 112, 114 (1924); see also Dix, supra, at 285 \& n.26 (noting that some early courts, while upholding the admissibility of statements obtained by deception, sometimes condemned the underlying conduct that produced the evidence).

${ }^{68}$ See, e.g., Tuttle v. People, 33 Colo. 243, 252-53, 79 P. 1035, 1039 (1905) (statements made at coroner's inquest are not "voluntarily made," and are not admissible); State v. Clifford, 86 Iowa 550, 551-52, 53 N.W. 299, 300 (1892) (statements 
accused following arrest is likely to be oppressed by the calamity of her situation, which makes her highly susceptible to external influence, especially by virtue of the suspect's intensified hopes and fears. The frailty of human personality, which greatly increases the likelihood of uttering untruths even when speaking the truth might be better, renders statements made under the influence of these sentiments too unreliable to be admitted in evidence.

The common sense proclaimed by McMahon was not universally accepted. Indeed, some courts explicitly questioned its "concession to the considerations of charity and regard for human weakness." siderations of the "public interests and a just regard for public safety" seemed to suggest that McMahon may have gone too far. ${ }^{70}$

Those opposed to the McMahon position argued that more than mere arrest would be needed before "mental excitement," caused by

made to grand jury under oath are not admissible if defendant has not been advised of her rights); Johnson v. State, 107 Miss. 196, 208-09, 65 So. 218, 219 (1914); Gilder v. State, 35 Tex. Crim. 360, 363, 33 S.W. 867, 870 (1896) (self-incriminating statements made while arrestee is testifying against another, without having been advised of her rights, are inadmissible); Maki v. State, 18 Wyo. 481, 490, 112 P. 334, 336 (1911) (statements made in response to coroner's inquiry are not voluntarily made); $c f$. State v. Coffee, 56 Conn. 399, 417, 16 A. 151, 154-55 (1888) (statements made voluntarily to grand jury are not an elicited confession and are admissible).

68 Teachout v. People, 41 N.Y. 7, 12 (1869); see People v. Owen, 154 Mich. 571, 576,118 N.W. 590,592 (1908) (" "WW]hen a criminal wants to ease his mind by a voluntary confession, it would be a weak sentimentalism to interfere with his doing so'." (quoting Commonwealth v. Clark, $130 \mathrm{~Pa} .641,650,18 \mathrm{~A} .988,989$ (1890))); see also $3 \mathrm{~J}$. WIGMORE, supra note 63 , at $\S 820 \mathrm{c}$ ("[T] in a confession-the danger of a false statement-is of a slender character, and the cases of that sort are of the rarest occurrence."). But see People v. Conte, 421 Mich. 704, 730, 365 N.W.2d 648, 658 (1984) (confession induced by promise of leniency renders it involuntary); People v. Louzon, 338 Mich. 146, 154, 61 N.W.2d 52, 56 (1953) (involuntary confessions cannot be used in Michigan state trials).

This debate continues today. See, e.g., People v. Conyers, 52 N.Y.2d 454, 458-59, 420 N.E.2d 933, 935, 438 N.Y.S.2d 741, 743 (1981). In Conyers, the majority held that the defendant's postarrest silence, which the state had used to impeach defendant's trial testimony, was inadmissible for lack of probative worth. The court noted that the defendant's silence could be attributable to an awareness of his right not to speak, natural caution from knowledge that his statements could be used against him, belief that efforts to exonerate himself would be futile, or the "lamentable but undeniable fact of modern society that some of our citizens harbor a mistrust for law enforcement authority." Id. at 458,420 N.E.2d at 935,438 N.Y.S.2d at 743 (citations omitted). In contrast, the dissent reached the opposite result, based on a very different view of human nature. The dissent argued that "[a]s to probativeness, its essence is that there is no more compelling instinct (and thus no greater force for truth telling) than that of self-preservation: 'it is natural to expect that one who has been outraged in person or property will make prompt disclosure or explanation, the more so when his or her failure to do so will result in his or her own arrest'." Id. at 461, 420 N.E.2d at 937, 438 N.Y.S.2d at 745 (Meyer, J., dissenting) (citing People v. Conyers, 49 N.Y.2d 178, 194, 400 N.E.2d 342, 355, 424 N.Y.S.2d 402, 416 (Meyer, J., dissenting), vacated, 449 U.S. 809 (1980)).

70 Teachout, 41 N.Y. at 12. 
"terror and apprehension," could render an accused's statements unreliable. ${ }^{71}$ Some threat of violence, some direct or implied promise, would need to be shown to account for an accused's falsely self-incriminatory statements. But courts could not agree upon the amount of influence beyond McMahon's "however slight" standard that was needed to exclude an accused's statements. On the one hand, it was thought that defendant's fear of being lynched by an angry mob, ${ }^{72}$ or his mistaken (or uninformed) beliefs about sentencing if convicted, ${ }^{73}$ or state promises of leniency ${ }^{74}$ might make an ordinary person confess falsely. On the other hand, police deceit, ${ }^{78}$ prolonged interrogation, ${ }^{76}$ or invocations to tell the truth ${ }^{77}$ seemed not to offset unduly the defendant's natural impulse to "clear himself by his own devices."78

The bounds of common sense that emerge from the cases are linked sub rosa to conflicting (unself-reflectively held) views of human nature. Whether confessions are "deserving of the highest credit, because [they are] presumed to flow from the strongest sense of guilt,"79 or whether "[t]oo great a chastity cannot be preserved on this subject, " ${ }^{30}$ depends upon the truths one takes as "self-evident" at the outset. Thus, common sense spawns its peculiar brood of conflicting outcomes, each one as seemingly obvious to its proponent as it is nonsensical to its opponent. In addition, the outcomes that make the most sense do so for deep-seated reasons that are largely hidden, for they are reasons that rest upon unreflectively held (putatively "selfevident") beliefs about the way people may be expected to behave under particular circumstances. The persuasiveness of an advocate's claims thus appears to hinge upon the sympathetic resonance it can achieve with the "common sense" of the court. However, there may or may not be a "common" common sense between the parties.

At early common law, the dialect of ordinary common sense not only governed the way jurists thought and talked about confessions, it also informed and guided their understanding of the meaning and per-

7 See, e.g., Coffee, 56 Conn. at 415, 16 A. at 154.

72 See, e.g., Thomas v. State, 169 Ga. 182, 184, 149 S.E. 871,872 (1929).

73 See, e.g., Mackmasters v. State, 82 Miss. 459, 461, 34 So. 156, 156 (1903).

74 See, e.g., Rutherford v. Commonwealth, $59 \mathrm{Ky}$. (2 Met.) 387, 391 (1859).

7s See, e.g., Commonwealth v. Spardute, 278 Pa. 37, 46, 122 A. 161, 165 (1923).

${ }^{76}$ See, e.g., Stein v. New York, 346 U.S. 156, 184-85 (1953), overruled, Jackson v. Denno, 378 U.S. 368 (1964).

77 See, e.g., People v. Klyczek, 307 Ill. 150, 154, 138 N.E. 275, 277 (1923).

${ }^{78}$ State v. Coffee, 56 Conn. 399, 415, 16 A. 151, 154 (1888).

${ }^{78}$ Hopt v. Utah, 110 U.S. 574, 584 (1884) (quoting The King v. Warickshall, 1 Leach 263, 263, 168 Eng. Rep 234, 235 (1783)).

${ }^{80}$ McMahon, 15 N.Y. at 397 (quoting The King v. Thompson, 168 Eng. Rep. $248,249(1783))$. 
missible uses at trial of a criminal defendant's silence. An historic maxim reflects the common wisdom: "he who is silent, agrees." commonsensical insight has long been enshrined in the common law "tacit admissions" doctrine.

Once again, ordinary expectations about human behavior rule the law. According to OCS, "everyone knows" that when an innocent person is confronted with accusations against her, she will spontaneously refute them if they are false. Human nature, and in particular the strong impulse for self-preservation, mandates such a response. Conversely, remaining silent in the face of such accusations is inconsistent with innocence. Such behavior otherwise would make no sense. True, there may be reasons that can explain the defendant's silence. If she hasn't heard the accusation, or if she's heard it but hasn't understood it, or if she understood it but isn't in a position to reply, her silence may not be inconsistent with innocence. If these conditions have been met, the doctrine of tacit admissions tells us, the only natural inference from silence in the face of accusation is guilt. Silence tacitly conveys the defendant's agreement with the charge. Bentham unabashedly articulates the main ideas at work in the law: "From the known principles of human nature, according to a course of observation common to all mankind, . . . between delinquency on the one hand, and silence under inquiry on the other, there is a manifest connexion; a connexion too natural not to be constant and inseparable."82

Here, we see natural expectations about human behavior dovetail with the OCS ability to recognize criminality when one sees it. Yet, a problem remains. There is no "common" common sense about how people should be expected to behave or what that behavior means. Notwithstanding Bentham's certainty on the subject, as well as the certainty of those courts that happen to share his particular common sense viewpoint, others adopt opposing views that, to them at least, are similarly "obvious."

${ }^{81}$ See Gamble, The Tacit Admission Rule: Unreliable and Unconstitutional-A Doctrine Ripe for Abandonment, 14 GA. L. REv. 27, 31 (1979) (illustrating the long history, from the maxim of Pope Boniface VIII, of the tacit admission rule).

${ }^{82} 5 \mathrm{~J}$. BenthaM, supra note 20, at 209.

${ }_{83}$ For example, a minority of courts have held that once a defendant was arrested, his silence could not later be used against him. As one court put it, the defendant "might well suppose that he had no right to say any thing until regularly called upon to answer." Commonwealth v. Kenney, 53 Mass. (12 Met.) 235, 238 (1847); see also State v. Epstein, 25 R.I. 131, 139, 55 A. 204, 208 (1903) ("He has the undoubted right . . . to keep silence as to the crime with which he is charged . . ." (quoting State v. Diskin, 34 La. Ann. 919, 921 (1882))). It should be noted that the court's use of the word "right" in Kenney (and in other similarly decided cases) is accompanied by no reference to any authoritative text. Apparently, the term "right" is being used in a common sense way-its import has to do with evidentiary reliability, not constitutional 
In short, as we have seen in the early cases involving confessions, the "self-evident" truths of OCS about a defendant's silence also gave rise to inconsistency and conflict in the case law. ${ }^{84}$ The question thus remains, how can a reasoned argument hope to dissuade a court that is committed to a contrary view of human nature? To be sure, resort to some form of "common wisdom," such as the wisdom traditionally found within popular maxims, is of no help. For such wisdom ranges widely. The popular maxim that says, "He who is silent, agrees," does not stand alone. It must compete with such common sayings as: "Even a fool, when he holdeth his peace, is counted wise," and "Wise men say nothing in dangerous times," and "Silence never shows itself so great an advantage, as when it is made the reply to . . . defamation." Nor is this list of competing maxims easily exhausted. ${ }^{85}$

The problem, then, is that there seems to be no empirical basis to prove the validity of any of these expressions of common wisdom. As Chief Justice Burger once observed: "It is no more accurate than to say, for example, that the innocent rather than the guilty, are the first to protest their innocence. There is simply no basis for declaring a generalized probability one way or the other."86 Yet, during the years

entitlement.

84 Compare O'Hearn v. State, 79 Neb. 513, 522, 113 N.W. 130, 134 (1907) ("A person in such a situation would naturally fear that the worst possible interpretation would be placed upon his language, that the memories of those present would lean to statements prejudicial to his interests, and that an officer seeking to convict might supply through zeal any defect in the statement which was actually made.") with Kelley v. State, 55 N.Y. 565, 572 (1874) (stating that "[i]t is no objection to the admission of the declarations of the accused, as evidence, that they are made while he is under arrest, and his admission, either express or implied, of the truth of a statement made by others under the same circumstances is equally admissible"), overruled, People v. Rutigliano, 261 N.Y. 103, 184 N.E. 689 (1933) (charge to jury that statements connected with defendant's silence were admissible evidence held erroneous); $c f$. Marsh v. State, 16 Ala. App. 597, 599, 80 So. 171, 173 (1918) ("II]n the absence of some good reason, it would be natural for one so seriously injured by . . . a heinous offense . . . to make immediate complaint to the authorities, and his failure to do so has some tendency to discredit his testimony.").

Underhill has noted, "The silence of the accused may spring from such a variety of motives, some of which may be consistent with innocence, that silence alone is only slight evidence of guilt." 2 H. UNDERHILl, CRIMINAL EvidENCE $§ 379$ (5th ed. 1956). But cf. 2 F. Wharton, A Treatise on THE LAW OF Evidence in CRiminal Issues $\S 678 \mathrm{~b}$ (1912) (" "[N]othing can be more dangerous than this kind of evidence'." (quoting Moore v. Smith, 14 Serg. \& Rawle 388, 393 (Pa. 1826))); id. at $\$ 680$ (citing cases to illustrate that "accusations and statements are not evidence against the accused where he remains silent . . . as he has the right to keep silence as to the crime, and is not called upon to reply to it, nor to contradict such statements.").

${ }_{85}$ Gamble, supra note 81, at 31-32.

${ }^{88}$ United States v. Hale, 422 U.S. 171, 181 (1975); see Comment, Tacit Criminal Admissions, 112 U. PA. L. REv. 210, 211 (1963) (noting that theories of human nature used by courts to support a claim that silence is consent "have not been empirically tested, but rest solely upon intuitive concepts of normal human conduct"); see also State 
prior to the first third of this century, when ordinary common sense dominated this area of the law, its conflicting truths continued to determine judicial outcomes. Courts swayed by the "self-evident" wisdom of one maxim or another, or by an unreflectively held, and thus unexplained and unjustified, view of human nature, interpreted a defendant's confessions or silence accordingly.

In sum, given the ascendancy of OCS talk about a defendant's confession or silence, conflict in the cases seems as inevitable as it was unresolvable. Because of its unreflectiveness, OCS tends to totalize even conflicting, "self-evident" truths about how people may be expected to behave, or what blameworthy conduct looks like. As a result, an advocate cannot discover how to offset those unquestioned presumptions that a court's unreflective and unsystematic thinking and speaking naturally engender. ${ }^{87}$

\section{B. Judicial Intuitions of Fairness: The Rise of Due Process}

According to ordinary common sense, our understanding of human behavior is a matter of ordinary observation. Our everyday expectations about how guilty people behave rest upon no special expertise-they are "what everyone knows." In the law of confessions, long dominated by this way of thinking and talking, each common sense view took its own assumptions as "self-evident," and therefore beyond question. As a result, no principled basis existed for influencing a particular deci-

v. Kobylarz, 44 N.J. Super. 250, 258-59, 130 A.2d 80, 85 (1957) ("[H]uman emotions and impulses constitute an erratic and unstable pedestal upon which to perpetuate a rule of law."), certif. denied, 24 N.J. 548, 133 A.2d 395 (1957).

${ }^{87}$ It should be noted that while clearly in the ascendant during this period of the common law, the dialect of OCS did not rule absolutely. That is, during these years a handful of courts eschewed OCS talk about silence and confessions for the sake of either a counter-intuitive reliance upon standards of institutional fairness, perhaps foretokening the rise of constitutional due process talk in the aftermath of Brown v. Mississippi, 297 U.S. 278 (1936), see, e.g., State v. Clifford, 86 Iowa 550, 552, 53 N.W. 299, 300 (1892); People v. Mondon, 103 N.Y. 211, 220, 8 N.E. 496, 500 (1886), or a reliance upon no less counter-intuitive talk about individual rights, perhaps foretokening the rise of Miranda v. Arizona, 384 U.S. 436 (1966), and the individual rights talk of the sixties and early seventies, see, e.g., People v. O'Bryan, 165 Cal. 55, 59-62, 130 P. 1042, 1045 (1913); Adams v. State, 129 Ga. 248, 253, 58 S.E. 822,824 (1907).

However, these early gropings toward some form of abstract fairness principle remained inchoate. The due process clause of the fourteenth amendment had not yet emerged as a source of authority for these courts' concerns. Instead, in reading these rather exceptional opinions, one comes across vague references to "a departure from our system of criminal jurisprudence," Mondon, 103 N.Y. at 220, 8 N.E. at 500, or to (unidentified) "fundamental principles" or to "unfair advantage," Clifford, 86 Iowa at 551,53 N.W. at 300 . Since these sentiments could not really be pinned down by the courts, and since the same courts also often engaged in common sense talk as well, it is little wonder that the dominance of OCS was hardly disturbed by such isolated and illarticulated decisions. 
sionmaker's view.

In addition, as long as OCS remained dominant in this area of the law, the federal courts lacked authority to intervene in state confessions cases, since such cases generally presented no constitutional or other federal issue. Moreover, at this time the United States Supreme Court, along with other courts in the federal judiciary, could not overturn state evidentiary rules. ${ }^{88}$ As a matter of OCS, this seems right. For what greater expertise could the federal courts claim in matters of "common wisdom"? While interpreting the fifth amendment privilege against self-incrimination might involve more expertise than a jury's common sense might reasonably be expected to provide, ${ }^{89}$ the privilege simply was not a factor in state confessions law at this time. Indeed, after having been heralded in Bram $v$. United States, ${ }^{80}$ without noticeably affecting the state courts' evidentiary (OCS) decisionmaking, ${ }^{91}$ the privilege was expressly deemed inapplicable to the states a decade later in Twining $v$. New Jersey. ${ }^{92}$ It would take another sixty years before the privilege would become a major factor in this area of the law. In the meantime, however, if the federal courts were to assume a more active posture toward local confessions law, some source of authority would need be uncovered.

In 1936, the court identified such a source. In a landmark case, Brown v. Mississippi, ${ }^{93}$ the Supreme Court set out upon a new path-the "constitutionalization" of state confessions law. The constitutional principle it now heralded was that "principle of justice" embodied in the due process clause of the fourteenth amendment to the Fed-

${ }^{88}$ Compare Twining v. New Jersey, 211 U.S. 78, 99 (1908) ("The exemption from compulsory self-incrimination is not a privilege or immunity of National citizenship.") with Malloy v. Hogan, 378 U.S. 1, 11 (1964) ("It would be incongruous to have different standards determine the validity of a claim of privilege based on the same feared prosecution, depending on whether the claim was asserted in a state or federal court.").

${ }^{8}$ Cf. Jackson v. Denno, 378 U.S. 368, 382 (1964) ("The jury, however, may find it difficult to understand the policy forbidding reliance upon a coerced, but true, confession, a policy which has divided this Court in the past . . . . That a trustworthy confession must also be voluntary if it is to be used at all, generates natural and potent pressure to find it voluntary. Otherwise the guilty defendant goes free.").

${ }^{80} 168$ U.S. 532, 548-49 (1897).

-1 See supra notes 16-21 and accompanying text.

82211 U.S. at 113 ("The wisdom of the exemption has never been universally assented to since the days of Bentham; many doubt it to-day, and it is best defended not as an unchangeable principle of universal justice but as a law proved by experience to be expedient." (citation omitted)).

93297 U.S. 278 (1936). Notably, outside the domain of confessions law, the Court had previously used due process talk to constitutionalize a state criminal case. See, e.g., Mooney v. Holohan, 294 U.S. 103 (1935) (holding that a criminal conviction knowingly procured by the state prosecuting authorities based solely on perjured testimony violates due process). 
eral Constitution.

Brown was an ideal vehicle for the federal court's intervention. The case involved a graphic display of police misconduct in an attempt to coerce a confession from the accused. In the case, state police officers admitted to hanging a murder suspect twice in quick succession from a tree limb in order to gain his confession. The second hanging was prompted by the failure of the first to persuade the defendant to admit his guilt. This official search for evidence next took the form of two severe whippings. The defendant, who was indigent and black, was warned that the whippings would continue until he confessed. In due course, the defendant agreed to confess to whatever statement the police had prepared for him. ${ }^{84}$ With this confession in hand, the state proceeded to trial and gained the defendant's conviction.

Defendant appealed, but the Mississippi Supreme Court rejected his claim that the confession should not have been admitted at trial. With full knowledge of the circumstances under which the confession had been obtained, the state court nevertheless perceived no violation of the law. ${ }^{95}$ The court's reasoning was straightforward. The jury had been properly instructed at trial to disregard any evidence that it found to have been coerced and of dubious veracity. Since by its ruling the jury apparently ruled out any official coercion in this case, the Mississippi court reasoned, the conviction could not be disturbed. ${ }^{96}$ In short, there was nothing more to be done.

Defendant appealed again. The United States Supreme Gourt not only agreed to hear Brown's case, it also concluded that he was right. The confession should not have been used against him at trial. One wonders, however, how a federal court can discount the common sense of a jury.

As it turned out, the Supreme Court did not question the jury's judgment regarding the trustworthiness of the defendant's confession. Nor had it the authority to do so. Nevertheless, as a matter of federal consitutional law, the Court unanimously renounced the Mississippi

94 Brown, 297 U.S. at 281-83.

9s Brown v. State, 173 Miss. 542, 557, 161 So. 465, 468 (1935), rev'd, 297 U.S. 278 (1936).

${ }^{96} I d$. at 564,161 So. at 466 . The court ruled that appellants waived their right to challenge the admission of their confessions by failing to object before the state closed its case. The trial court's subsequent failure to exclude the confessions was not deemed to violate due process. Id. at 568,161 So. at 468 . But cf. id. at 579,161 So. at 472 (Griffith, J., dissenting) (" $[\mathrm{N}] \mathrm{o}$ court shall by adoption give legitimacy to any of the works of the mob, nor cover by the frills and furbelows of a pretended legal trial the body of that which in fact is the product of the mob, and then, by closing the eyes to actualities, complacently adjudicate that the law of the land has been observed and preserved."). 
courts' rulings. In applying the due process clause of the fourteenth amendment to the states, the Court declared: "It would be difficult to conceive of methods more revolting to the sense of justice than those taken to procure the confessions of these petitioners, and the use of the confessions thus obtained as a basis for conviction and sentence was a clear denial of due process." the truth or falsity of the defendant's confession. Rather, it focused on the means by which the police procured the self-incriminatory evidence.

This shift of focus is readily discernible from the language of the opinion. In two paragraphs the Court uses the word "pretense" three times and the word "mask" once to describe trials that use evidence procured by methods such as those used in Brown. ${ }^{98}$ The "wrong so fundamental that it made the whole proceeding a mere pretense of a trial and rendered the conviction and sentence wholly void," wrong of constitutional dimension precisely because, according to Brown, the due process clause entitled the accused to a "fair" trial. Read in this way, due process embodies a fundamental institutional norm. A trial that violates this norm may result in a conviction based upon the "truth," but, if that truth was obtained unfairly, it must be excluded, even if this means that the factually guilty offender goes free. ${ }^{100}$

In Brown, then, the Court moved away from the OCS quest for factual guilt, shifting its focus from the accused to the accuser-that is, to the state and its agents. ${ }^{101}$ An implicit message here is that the judiciary will not condone state police brutality in producing a defendant's "confession." As the Court would later make clear, use of evidence from such a source signals judicial complicity. ${ }^{102}$

Viewed retrospectively, Brown opened a new chapter in the law of

97297 U.S. at 286.

98 Id.

${ }^{89} \mathrm{Id}$.

100 See Rogers v. Richmond, 365 U.S. 534, 541 (1961) (opposing convictions based on coercion, not because they were not true, but "because the methods used to extract them offend an underlying principle in the enforcement of criminal law: that ours is an accusatorial and not an inquisitional system . . . .").

101 See C. MCCormick, ON Evidence $\S 147$ (3d ed. 1984) (listing the components of the "complex values" that the Court terms involuntary, including the discouragement of unacceptable police practices).

${ }^{102}$ See, e.g., Miranda v. Arizona, 384 U.S. 436, 480 (1966) ("Crime is contagious. If the government becomes a law-breaker, it breeds contempt for law; it invites every man to become a law unto himself; it invites anarchy." (quoting Olmstead v. United States, 277 U.S. 438, 485 (1928) (Brandeis, J., dissenting))).

For an early (and eloquent) statement of this principle, see SoPHOcles, PHILOCTETES, in Sophocles II 189, 250 (D. Grene \& R. Lattimore eds. 1957) ("You will not then, by helping the wicked, seem to be like them."). 
confessions. Ordinary expectations about how people behave, and what that behavior signifies, no longer seemed adequate to do justice under circumstances such as those presented by the Brown case. Nor was the drama that Brown portrayed an isolated one. Indeed, the use of improper police interrogation for the purpose of eliciting confessions had become a subject of special concern in the nation, at least since the 1931 Wickersham Commission report on police abuses. ${ }^{103}$ Yet, over twentyfive years after the Brown decision, during which time the federal courts struggled with-and the state courts mostly ignored ${ }^{104}$-this shift into due process discourse, no clear federal standard emerged. ${ }^{105}$ If ordinary common sense was no longer ascendant, the kind of legal expertise that was to replace it remained a question in its own right.

That question was fated to remain open. For upon closer scrutiny, the "expertise" that emerged in Brown and its progeny apparently rested solely on judicial intuition. That is, the "involuntariness" of a confession may now have been linked to a perceived violation of "due process," but the principled basis for such a perception, and what exactly this constitutional standard meant, seemed to depend on both a particular court's sense of fairness and the particular circumstances of the case before it. ${ }^{106}$ In this respect, the situation was as Lord Seldon described so many years ago in regard to the meaning of equity:

'Tis all one as if they should make the Standard for the measure, we call a Foot, a Chancellor's Foot; what an uncertain Measure would this be? One Chancellor has a long Foot another a short Foot a Third an indifferent Foot: 'tis the same thing in the Chancellor's Conscience. ${ }^{107}$

${ }^{103}$ See Stone, The Miranda Doctrine in the Burger Court, 1977 SuP. Cr. REv. 99, 101 (1977). The Wickersham Commission report is reported in 4 National COMM'N ON LAw OBSERVANCE and ENFORCEMENT, REPORT ON LAWLESSNESS IN LAW ENFORCEMENT (1931) (examining in detail problems of police interrogation and abuse of authority).

104 See Dix, supra note 67, at 294, 306 n.117 (noting that the state courts tended to cite to prior state decisions rather than to decisions of the Supreme Court).

${ }_{105}$ See Grano, Voluntariness, Free Will, and the Law of Confessions, 65 VA. L. REV. 859, 863 (1979) (noting that the Court's failure to set a clear standard resulted in years of confusion).

${ }^{106}$ See Ogletree, Are Confessions Really Good for the Soul?: A Proposal to Mirandize Miranda, 100 Harv. L. Rev. 1826, 1833 (1987) (noting the Court's vacillation in this period and the inadequacy of due process analysis for different contexts and circumstances); see also C. MCCormick, supra note 101, $\S 147$ (noting some of the various contexts that require case-by-case subjective due process analysis).

${ }_{107}$ TABle TalK of JoHn Selden 49 (S. Singer ed. 1855). Compare Twining v. New Jersey, 211 U.S. 78, 123 (1908) (Harlan, J., dissenting) ("II]t is common knowledge that the compelling of a person to [in]criminate himself shocks or ought to shock the sense of right and justice of every one who loves liberty.") with Adamson v. California, 332 U.S. 46, 65 (1947) (Frankfurter, J., concurring) ("If the basis of selection [as 
In the plethora of post-Brown confession cases, each instance presented its own multiplicity of facts and required its own customized judicial response. ${ }^{108}$ As a result, articulation of the precise meaning of due process awaited the next Supreme Court pronouncement. Since no two cases were alike in their details, the Court's response to particular allegations of police misconduct could not be predicted with any certainty. ${ }^{100}$ While the court dockets overflowed, the courts came no closer to clarity. ${ }^{110}$

In Lisenba $v$. California, ${ }^{111}$ for instance, the defendant claimed that his confession had been obtained by police coercion in the form of continuous, incommunicado interrogation over a two-day period. During this time defendant was questioned by teams of officers who allegedly deprived him of sleep, withheld food, and beat him during the interrogation process. Police conceded he had been slapped once, but denied any allegations of significant physical abuse. ${ }^{112}$

The Court in Lisenba found that, notwithstanding the defendant's contentions, due process had not been violated. ${ }^{113}$ While noting the illegality of the failure by police to bring defendant before a Magistrate promptly, the Court nevertheless ruled that the level of abuse necessary

to which of the Bill of Rights are to be incorporated into the due process clause of the fourteenth amendment] is merely that those provisions of the first eight Amendments are incorporated which commend themselves to individual justices as indispensable to the dignity and happiness of a free man, we are thrown back to a merely subjective test.").

108 See Ogletree, supra note 106, at 1832-33.

109 Cf. Schulhofer, Confessions and the Court (Book Review), 79 Mich. L. Rev. 865,869 (1981) (reviewing Y. Kamisar, Police Interrogation and Confessions (1980)) (noting that the police did not derive any firm guidance from the Court's unwillingness or inability to construct a clear standard).

110 See 3 J. Wigmore, supra note $63, \S 826$ (listing numerous factors that the Court had considered as bearing on voluntariness); Dix, supra note 67, at 292-94 (noting that the Court had failed to address fully the implications of the phrase "fundamental unfairness" as used in the due process standard).

Notably, the Court's new sensitivity to "due process" did not mean the law now favored the accused more than before. According to Bram, (and, as a matter of local evidentiary law, for those states following McMahon's more liberal, nonconstitutionalized, outlook upon human nature) confessions produced by threats or promises "however slight" would be excluded. Under the due process standard, however, the outcome was less clear. For example, when a confession was obtained in response to a police assertion that cooperation would facilitate prompt release on bail or that the defendant would fare better in subsequent proceedings, the cases have gone both ways. See J. Israel \& W. LaFave, Criminal Procedure 308-09 (abridged ed. 1985).

111314 U.S. 219 (1941).

112 See id. at 230-32. This type of debate, an incessant "swearing contest" between the accused and the accuser, is a hallmark of the due process cases. See Y. Kamisar, W. Lafave \& J. Israel, Modern Criminal Procedure 523 (6th ed. 1986).

${ }^{113}$ Lisenba, 314 U.S. at 234-35, 240-41. 
for a due process violation had not been reached.114 Consistent with Brown, the Court noted that due process embodies a different standard from the traditional (OCS) evidentiary standard used by the various states. ${ }^{115}$ The Court recognized, however, that the due process "voluntariness" standard used by the judge and jury in the state courts below was not the correct federal standard but curiously continued to rely upon the federal determination. ${ }^{118}$

Thus, by assessing due process on the basis of the lower court's evidentiary reliability talk, the Court here, as it had in Bram v. United States, commingled the two standards. ${ }^{117}$ A similar confusion occurred in Stein v. New York. ${ }^{118}$ There, sixteen years after constitutional due process had been introduced into the law of confessions, the Gourt concluded that the jury was fully equipped to assess the "voluntariness" of a defendant's confession. By thus sanctioning what was then referred to as the "New York" rule, ${ }^{119}$ the Gourt in effect allowed the lay jury's ordinary common sense to shape and inform the meaning of the constitutional standard. As in Lisenba, the practical result of this ruling was a step back from "due process" to the traditional search for factual guilt that ordinary common sense "naturally" champions. Indeed, once "voluntariness," as a matter of fair process, and "reliability," as a matter of factual trustworthiness, are allowed to run into each other, the latter is likelier to govern. This is so because, as Bentham put it, the "artificiality" (or counter-intuitiveness) of legal abstractions is "naturally" resisted by ordinary common sense. ${ }^{120}$ As a matter of ordinary

114 Id. at 236-38; see also Ogletree, supra note 106, at 1833 (noting that the extreme conduct of the police in Brown may have "led courts . . . to view other cases of compelled confessions as moderate by comparison").

${ }^{116}$ Lisenba, 314 U.S. at 236. The choice the Court perceived was between reliability (a "risk [that] the confession is false") and fairness ("a deprivation of the prisoner's life or liberty without due process of law"). Id.

116 Id.

117 See Note, Developments in the Law of Confessions, 79 HaRv. L. Rev. 935, 960 (1966) (noting that the Court may not have intended the merging of the standards to be as innovative as the language might imply).

118346 U.S. 156, 177 (1953).

119 See C. MCCormick, supra note $101, \S 161$, (rule requires judge to make preliminary determination of voluntariness, and if the evidence presents a "fair question" of voluntariness, the judge must submit the issue to the jury).

${ }^{120}$ See $5 \mathrm{~J}$. BENTHAM, supra note 20, at 15 (stating that legal principles function "abstractly" and thus work against the "natural sagacity of the jury"); see also Bram, 168 U.S. at 570 (Brewer, J., dissenting) (describing the Court's construction and application of the fifth amendment privilege against self-incrimination as involving "a refinement of analysis which, while it may show marvellous [sic] metaphysical ability, is of little weight in practical affairs."); $c f$. Dix, supra note 67, at 333 n.214 ("The [fifth amendment] privilege is based in part on an almost metaphysical notion that encouraging a person to participate in his own 'downfall,' i.e., his criminal conviction, is inconsistent with the person's inherent dignity as a human being, whether or not he is 
expectations, to free the factually "guilty" offender for the sake of some abstract principle "makes no sense." With the concrete "search for truth" perspective restored, police misconduct becomes "reprehensible not because it violates an institutional norm of fair process, but rather because of the likelihood that it will produce untrustworthy confessions. ${ }^{121}$

In his dissenting opinion, Justice Frankfurter expressed regret at the Stein Court's "retrogressive step" in the administration of criminal justice. ${ }^{122}$ And for their part, commentators have viewed Stein as an anomaly. ${ }^{123}$ Other cases support this view. ${ }^{124}$ Nine years later, in Jackson v. Denno, ${ }^{125}$ Stein was expressly overruled.

Contrary to Stein, the Jackson decision conceded that a jury may indeed be ill-suited to do justice to a defendant's full constitutional entitlement. ${ }^{126}$ In this respect, the Jackson Court appeared to take heed of the changes, stemming from Brown's constitutionalization of state confession law, in the way a decisionmaker might ordinarily think and talk about this type of evidence. Dialogically expressed, the Court's message was that if ordinary common sense cannot reconcile itself with or do justice to counter-intuitive, "artificial" rules of law, then the Court must take those procedural steps necessary to safeguard the application of such rules in the appropriate case. ${ }^{127}$ Judicial assessment of the "vol-

guilty.").

${ }_{121}$ See Stein, 346 U.S. at 181-82.

122 Id. at 201 (Frankfurter, J., dissenting).

123 See, e.g., $3 \mathrm{~J}$. WIGMORE, supra note 63, § 822.

124 See, e.g., Gallegos v. Nebraska, 342 U.S. 55, 63 (1951); Lyons v. Oklahoma, 322 U.S. 596, 597 (1944).

128378 U.S. 368, 391 (1964).

${ }^{128} I d$. at 382; see supra text accompanying note 89.

127 See Jackson, 378 U.S. at 382; cf. Bruton v. United States, 391 U.S. 123, 126 (1968) ("[B]ecause of the substantial risk that the jury, despite instructions to the contrary, looked to the incriminating extrajudicial statements in determining petitioner's guilt, admission of [codefendant] Evans' confession in this joint trial violated petitioner's right of cross-examination . . .."). But see id. at 142-43 (White, J., dissenting) ("It is a common experience of all men to be informed of 'facts' relevant to an issue requiring their judgment, and yet to disregard those 'facts' because of sufficient grounds for discrediting their veracity or the reliability of their source. . . . [S]erious-minded and responsible men are able to shut their minds to unreliable information when exercising their judgment . . . .").

The crowning irony in this trajectory came 13 years later in Carter v. Kentucky, 450 U.S. 288 (1981). In Carter, the Court seemed to take for granted the lay jurors' ability to comprehend abstract (constitutional) principles of law: "Jurors are not experts in legal principles; to function effectively, and justly, they must be accurately instructed in the law. Such instructions are perhaps nowhere more important than in the context of the Fifth Amendment privilege against compulsory self-incrimination . . . "Id. at 302 (citation omitted).

At this point, one is left to wonder if a jury can understand such principles; indeed, if the jurors have the right to be informed of them, how can the Jackson Court's 
untariness" of a defendant's confession in advance of exposure to the jury was the specific safeguard Jackson provided to ensure that the proper constitutional standard was applied. This introduced the possibility of no jury review at all, should the police conduct in question be deemed "fundamentally unfair" by the Court.

Notwithstanding the assessments of the Court and the commentators, the Stein decision is more than a simple anomaly. Indeed, in view of the Court's inability since Brown clearly to explain and justify the due process standard with any consistency, one may suggest that Stein makes perfect sense. In some respects, given the nature and questionable legitimacy of due process jurisprudence, there may be reasons to prefer Stein to Jackson.

While the Jackson Court explicitly addressed the lay jury's inability to reckon with difficult constitutional standards, one obvious question remains: What is the basis for the Court's superior "expertise" in this matter? On what basis may the Court legitimately remove from the jury's purview the issue of voluntariness? Judging from the cases, there appears to be none. To the extent that the due process clause of the fourteenth amendment serves merely to mask the federal courts' multifarious intuitions of fairness, and to the extent that shifting, putatively "self-evident" imperatives of judicial conscience take the place of reasons explaining and justifying specific outcomes, common sense has not been superseded at all. It has only been relocated-from juror to judge. And common sense is anything but a form of expertise. ${ }^{128}$

claim, regarding the limitations of the jury's comprehension, remain valid? stating:

${ }^{128}$ For example, Justice White "justified" the Court's holding in Jackson by

[B]ecause of the "strongly felt attitude of our society that important human values are sacrificed where an agency of the government, in the course of securing a conviction, wrings a confession out of an accused against his will," and because of "the deep-rooted feeling that the police must obey the law while enforcing the law; that in the end life and liberty can be as much endangered from illegal methods used to convict those thought to be criminals as from the actual criminals themselves."

Jackson, 378 U.S. at 386 (citations omitted) (emphasis added).

If Justice White is correct about this, one wonders why the defendant must be protected from the jury's possible failure to reflect the "strong attitude" and "deep feelings" to which White refers. Moreover, if the Court, but not the ordinary lay person, is uniquely privileged to reflect society's values, one wonders why lay people are not at least entitled to know the source and justification for the Court's pronouncements-that is, aside from the Court's feelings of rightness.

As for the judicial "expertise" to which courts may legitimately lay claim in interpreting due process, see Adamson v. California, 332 U.S. 46, 65-66 (1947) (Frankfurter, J., concurring) ("We are called upon to apply to the difficult issues of our own day the wisdom afforded by the great opinions in this field . . . This guidance bids us to be duly mindful of the past, with its great lessons of how liberties are won and how they are lost." (citations omitted)). 
Putting the matter more explicitly, observational OCS talk, which focuses upon how guilty people are ordinarily expected to behave, and intuitive due process talk, which focuses upon what kind of police misconduct strikes a particular judge as unfair, are but two sides of the same coin. They reflect the empirical and rational forms of common sense. In either case, whether as a matter of ordinary observation or judicial intuition, common sense meanings prevail. That is, in either case, neither reflection nor genuine interpretation occurs. The reason is simple: there is no self-reflective standpoint from which to question what otherwise appears to the observer as "self-evidently" "true" or "fair." Admittedly, in the due process cases that followed Brown's lead, the courts paid lip service to the due process clause of the fourteenth amendment. The practical result of this talismanic gesture, however, was clear: the unruliness of facts triumphed, and principle became their captive. ${ }^{129}$

One may agree that it is interpretation of this sort that gives substance and legitimacy to the meaning of specific constitutional (and other) texts. Indeed, in the following section, this Article will argue that this is the chief virtue of the dialect referred to as Prudent Interpretation. However, absent reasons that reflectively and persuasively justify particular interpretations and their contextual application to particular cases, such interpretive decisionmaking becomes suspect, which is precisely the danger the due process cases have reflected in practice. This is not to say that less suspect interpretation in this area could not have been generated by more reflective decisionmaking. As evidence of the difficulties involved, however, note one of Justice Frankfurter's own putatively "self-evident" justifications for not applying the fifth amendment privilege against self-incrimination to the states through the due process clause of the fourteenth amendment:

Sensible and just-minded men, in important affairs of life, deem it significant that a man remains silent when confronted with serious and responsible evidence against himself which it is in his power to contradict. The notion that to allow jurors to do that which sensible and rightminded men do every day violates the "immutable principles of justice" as conceived by a civilized society is to trivialize the importance of "due process."

Id. at 60 (Frankfuter, J., concurring); cf. Sweezy v. New Hampshire, 354 U.S. 234, 267 (1957) (Frankfurter, J., concurring) (arguing that the judicial balance of the individual's interest in political privacy with the state's interest in self protection inherent in the substantive content of the due process clause "must not be an exercise of whim or will. . . . It must rest on fundamental presuppositions rooted in history to which widespread acceptance may fairly be attributed."). Whether "objective" criteria for this type of judgment can be found, however, remains problematic.

${ }_{129}$ See $3 \mathrm{~J}$. WIGMORE, supra note $63, \S 826$ (straining to determine coherent understanding of voluntariness); see also Dix, supra note 67, at 306-10 \& 308 n.124 (noting how some courts required defendant to show "deception," yet found no deception even though the facts suggested otherwise).

In this sense, the ease with which Stein, Lisenba, along with numerous other federal court opinions, still used "reliability" talk years after Brown was decided should not be surprising. Due process talk did little in practice to challenge, much less overcome, OCS resistance to counter-intuitive legal abstractions. And thus it should come as no surprise to see in 1963, almost 30 years after Brown had brought due process talk into the law of confessions, two state courts and two federal courts still were able to 
In sum, to the extent that due process talk failed to explain and justify specific outcomes as a matter of self-reflective constitutional interpretation-rather than mere intuition-the same resistance to abstraction that had characterized the pre-Brown ascendancy of (empirical) common sense persisted. Thus, a troublesome question remains. What is it about putatively "self-evident" judicial intuitions of fairness that qualify them as a special form of expertise? The cases and the scholarly literature of the time are instructive, for it is not only the federal courts' conflation of OCS "reliability" and constitutional "voluntariness" standards that casts doubt upon the court's expertise. The inconsistency and unpredictability of case outcomes, ${ }^{130}$ along with the spectre of judicial subjectivity and the decisional illegitimacy such inconsistency invites, suggest that no such "intuitive" expertise existed. If this claim is correct, then why isn't a jury of twelve better, or at least as well equipped, as the Stein Court had contended it was, to reflect a consensus, a "common" common sense about the meaning of "fairness?"

Not surprisingly, given the kind of discourse that intuitive due process decisionmaking engages, the cases decided in the aftermath of Brown involving defendants' pretrial silence further illustrate the inefficacy of this type of decisionmaking. For the more than twenty-five years during which time the Brown heritage prevailed, the conflict in this area of confessions law raged unabated. What is more, Brown's notion of due process seems to have had almost no impact upon the state courts. For example, in perhaps the majority of jurisdictions, the fact of arrest was deemed sufficient to preclude, as a matter of law, any

conclude that a confession, elicited by police after 16 consecutive days of detention and interrogation, was admissible as evidence at trial. See State v. Haynes, 58 Wash. 2d 716, 723-24, 364 P.2d 935, 939-40 (1961) vacated sub nom. Haynes v. Washington, 373 U.S. 503 (1963); of. Commonwealth v. Graham, 408 Pa. 155, 163-64, 182 A.2d 727,731 (1962) ("The admissibility of confessions is to be judged on their evidentiary trustworthiness. . . . It is our considered conclusion that the voluntariness and trustworthiness of [defendant's] confessions were for the jury."). But see id. at 164, 182 A.2d at 731 (Cohen, J., dissenting) ("The admissibility of the confession presents a question of law for the court's summary disposition.").

${ }^{130}$ The kind of police pressures complained of in Haynes, namely, prolonged incustody interrogation of the accused while isolated from family and counsel, initially failed to evoke judicial outrage. But see Leyra v. Denno, 347 U.S. 556 (1953), where a confession was excluded under far less trying circumstances. In that case, a police psychiatrist posing as a physician urged the defendant to confess to a murder of which defendant stood accused. The confession was made, but the Supreme Court barred its use as evidence at trial. Contrary to Haynes, no police violence and no threats of violence were ever alleged by the accused. Defendant's fatigue and susceptibility to suggestion were all that was needed to make the method of obtaining the confession constitutionally impermissible. Id. at 559-61. 
evidentiary use of defendant's in-custody silence. ${ }^{131}$ The pressures inherent in the custodial environment and the mental agitation this environment can cause the accused were the familiar rationales that recurred in these cases. ${ }^{132}$ Applying traditional evidentiary analysis, these courts found that the prejudicial effect of using a defendant's silence against her outweighed its probative value. Yet, in other jurisdictions defendant's arrest was but one factor among others for a jury to consider in assessing the evidentiary worth of the accused's pretrial silence. $^{133}$

As for the Court itself, the constitutionalization of state confessions law did not yet go so far as to displace evidentiary rules concerning pretrial silence. In Grunewald $v$. United States, ${ }^{134}$ for instance, the court condemned a prosecutor's reference at trial to defendant's invocation of the privilege against self-incrimination during a grand jury hearing. The Court reasoned that defendant's silence before the grand jury was not inconsistent with his exculpatory testimony later at trial. Thus the familiar (common sense) evidentiary test-inadequate probative value measured against undue prejudice-governed the Court's decision. As the Court put it, defendant's silence was "wholly consistent with innocence."135 Here again, we see that it is the Court's attitude toward human nature, how innocent people may be expected to behave during a pretrial hearing and what that behavior means, not a selfreflective, articulated constitutional principle, that is dispositive. At this point, then, law talk about the state's use of defendant's pretrial, selfincriminating silence lacked any constitutional overtones whatsoever. In sum, while giving federal decisions the appearance of constitutional interpretation, after the ritual incantation of due process, the federal courts ended up simply indulging their own unreflective sense of what was fair under the particular circumstances of each case. Due process, it turned out, was but a phrase to mask a particular court's intuitive

131 See, e.g., Rickman v. State, 230 Ind. 262, 267, 103 N.E.2d 207, 210 (1952); Commonwealth v. Locke, 335 Mass. 106, 114, 138 N.E.2d 359, 365 (1956); People v. Allen, 300 N.Y. 222, 225, 90 N.E.2d 48, 49-50 (1949); Walker v. State, 80 Okla. Crim. 21, 23, 156 P.2d 143, 144 (Crim. App. 1945); De Lira v. State, 164 Tex. Crim. 194, 196, 297 S.W.2d 953, 954 (Crim. App. 1956); see also 3 J. WIGMORE, supra note 63, § 783; cf. Comment, Impeaching a Defendant's Trial Testimony by Proof of PostArrest Silence, 123 U. PA. L. REv. 940, 943-44, 943 n.16 (1975) (compilation of federal cases post-Miranda).

${ }_{132}$ See supra text accompanying note 63; see also Wharton's Criminal EviDENCE, $\S \S 680-83$ (13th ed. 1972) (promises of benefit and leniency); 3 J. WIGMORE, supra note 63, $\S 826$ (custody and voluntariness); 29 AM. JuR. 2d Evidence $\S \S 610$ 14 (1977) (constraints on confessions).

133 G. MCCormick, supra note 101, § 149.

134353 U.S. 391 (1957).

138 Id. at 421. 
sense of (self-evident) "rightness." The rhetoric had shifted (from common sense to seemingly counter-intuitive constitutional interpretation), but the cognitive mode, based upon putatively "self-evident" intuitions, remained the same. Only now, rather than leaving a jury to decide whether a particular defendant had acted in a way guilty people are expected to, the courts determined for themselves whether particular police actions were sufficiently unfair to render moot the question of criminal blameworthiness. For the reasons suggested above, the courts' due process talk represents a peculiar hybrid. On the surface, it invokes constitutional principle, but upon closer scrutiny, the attributes of genuine textual interpretation are lacking. In other words, due process talk neither explains nor justifies the basis for its conclusions. Instead, conclusions emerge in the same fashion as the "self-evident" truths of ordinary common sense. Although "values" are necessarily involved, they remain inchoate and elusive, quietly embedded within the unquestioned premises of a particular legal dialect. In this respect, the courts' due process discourse in this area is but pseudo-interpretation. ${ }^{\mathbf{1 3 6}}$ Simply stated, whether the intuition comes from the lay person or the legal expert, the effect is the same: intuitions (about manifest criminality on the one hand, or unfair police practices on the other) characteristically fail to provide persuasive reasons that can be generalized from one set of circumstances to another.

It is this failure to provide principled and at least minimally predictable outcomes that produced unrelenting conflict and uncertainty in the case law. Moreover, this situation ultimately fuels skepticism about the legitimacy of the judicial decisionmaking process itself. ${ }^{137}$ Given this posture of events, any virtues that Brown's dialogic innovation had brought to the law of confessions could not withstand the weight of its defects. ${ }^{138}$

136 The notion of pseudo-interpretation may be compared to what Vygotsky calls "pseudo-concepts." See L. Vygotsky, Thought AND Language 118-24 (1962).

${ }^{137}$ Charges of judicial subjectivity, together with related questions about the dubious legitimacy of the Court's due process jurisprudence, emerged with increasing urgency from all sides. See, e.g., 3 J. WIGMORE, supra note 63, at $\S 826$ ("To the extent "voluntariness" has made a determination of the state of an individual's will the crucial question, it has not assisted analysis'." (quoting AMERICAN LAw INSTITUTE, Model. Code of Pre-Arraignment Procedure 166-67 (Tentative Draft No. 1, 1966))); Dix, supra note 67, at 294-95 (noting that the due process test inadequately dealt with less blatant police misconduct); $c f$. Culombe v. Connecticut, 367 U.S. 568, 601 (1961) (acknowledging in less critical terms the fact that there is no "single litmuspaper test" for determining voluntariness under the due process clause).

138 If Brown's putative departure from the traditional standard of evidentiary reliability - for the sake of its own pseudo-interpretative common sense discourse-left the states' talk about confessions and pre-trial silence largely unchanged, while confusion on the federal level only deepened, this is not to say that the judicial intuitions that 
If this predicament was to be overcome, the courts would need to find a way to unify disparate judicial intuitions. As Justice Harlan warned, the lack of stability had reached a point where "the States cannot be sure from one year to the next what this Court in the name of due process will require of them . . .."139 To obtain the kind of stability that was needed, resistance to abstract principle would need to be overcome. To achieve this goal, however, a new mode of discourse was required-a way of thinking and talking about pretrial confessions and silence that could master (rather than serve) the endless complexities of unruly facts.

In the 1960s, a new kind of law talk about pretrial confessions and silence emerged. Due process, that hybrid dialect and vestige of common sense (unprincipled) intuition, would now give way to the discrete and highly controversial criminal procedure dialect that this Article refers to as Prudent Interpretation.

\section{Prudent Interpretation and the Authority of Inherited Texts: Criminal Process as the Search for Meanings}

Rather than certainty, which derives either from unreflective and inconsistent or self-consciously unified, "self-evident" premises, the strain of controversy lies close to the heart of Prudent Interpretation. According to this view, on the one hand the Court finds itself situated within history, the guardian of inherited texts and procedures. In this role, the Court acts as prudent watchguard, following extant rules and principles. On the other hand, the Court feels the need to revitalize "impotent and lifeless formulas" and to resist "narrow and restrictive construction."140 Responding to this need, unlike in its backward-looking role as guardian, the Court searches for current textual meanings. Thus, the tension of PI is played out as a drama of (re)interpretive conservation and reform.

According to this way of thinking and talking about the law, once self-reflectively encountered, history always bears a contemporary face; its meanings are always newly unfurling within specific, concrete contexts. ${ }^{141}$ Yet, it is the historical text that is being interpreted. Because

make up due process talk in this area of the law were not without significance. During this period in the development of confessions law, the Court's understanding of criminal process was enlarged. For the first time, safeguarding an abstract institutional value and the search for trustworthy evidence in pursuit of the factually guilty were given an embodied existence in both federal and state confessions cases.

138 Jackson, 378 U.S. at 440 (Harlan, J., dissenting).

140 Miranda v. Arizona, 384 U.S. 436, 443-44 (1966) (quoting Weems v. United States, 217 U.S. 349,373 (1910)).

${ }_{141}$ To test this thought, consider the following reflection: Could that which we 
of the uncertainty produced by this tension between past and present, particular interpretations require reasons that persuasively explain and justify their correctness and applicability under particular circumstances. Put simply, within the PI perspective, there is no alternative other than to accept the burden of controversy and the responsibilities of reasoned debate as a point of departure for judicial decisionmaking.

Thus, for those who engage PI, there is no escape to some "neutral" ground-whether it be the putative "objectivity" of past meanings, the unreflective "self-evidence" of a moment's (common sense) intuition, or the studied "self-evidence" of a preferred policy's prospective ideals. The yearning for certainty, neutrality, or objectivity now appears, at best, quixotic, and at worst, delusory. Indeed, the expertise to which jurists may legitimately lay claim is borne of this realization. ${ }^{\mathbf{1 4 2}}$

By the early 1960s, the limitations of due process talk about confessions had become too prevalent to be ignored. Simple reference to "voluntariness," what Justice Frankfurter disingenuously described as the "ultimate test ... clearly established ... in Anglo-American courts for two hundred years,"143 could no longer coherently contain the multiplicity of situations that this standard had come to embody. The range of possibilities was too broad. To those for whom voluntariness meant the ability to choose from among various alternatives, perhaps the accused's every word and silence while in police custody was voluntary. To those who asked whether the suspect's "choices" would have been made at all but for the intervention of the police, it is possible that no custodial statement or silence would remain voluntary.

In any event, as things remained, the strong "natural" impulse to solve crimes (i.e., to "put criminals away") was far likelier to guide police, and local courts for that matter, than some ill-defined, federal standard of fairness that required on the spot assessments of a suspect's peculiar susceptibility to police influence. Whether police are equipped to make such assessments, and whether their own self-exculpatory claims in response to charges of misconduct are worthier of belief than

should know best, i.e., our sense of self-that unique being-in-history-amongothers-be less clear than our knowledge of others acting in a different place and time, or that class of others called historians who narrate the meaning of past events? Yet, upon closer reflection, how coherent is our sense of self over time? How many gaps do we manage to cover, much less discover? Can we find, then, within the historian's account of others, clearer insights than those we reflectively encounter within a current context? Is it not the reader's sense of self that accounts for how she may encounter, and reflectively assess, the historian's insights and that permits the encounter with one or more insights to occur in the first place? How then is what we know and understand about history to be divorced from who we are today?

${ }^{242}$ See supra text accompanying notes 29-30.

143 Culombe v. Connecticut, 367 U.S. 568, 602 (1961). 
the accused's allegations of police abuse-claims certainly no less motivated by self-interest-are but further conflicts the cases had to endure. ${ }^{144}$

Troubled by the seeming subjectivity of intuitive, ad hoc decisionmaking, and responding to the felt need for increased order and predictability in the case law, the Supreme Court began to cast about for some way to unify the sprawling complex of due process decisions. ${ }^{145}$ As a result, the Court's pseudo-interpretive (intuitive) reactions to a disparate array of facts and values began to give way to a new way of thinking and talking. This new discourse revealed the Court's heightened self-consciousness in the search for increasingly abstract, interpretive principles. The Court's search focused upon authoritative texts. ${ }^{148}$ The question that had to be faced at the outset, however, was which text to apply and how to apply it. Several factors quickly emerged as candidates for the new interpretive framework. Despite the absence of any discernible pattern in the cases, in almost all of them the defendant had been held incommunicado-isolated from friends, family or legal counsel. In about one-third of the cases, the defendant was not told of the right to remain silent, nor of the right to counsel, nor of the consequences of speaking while in police custody. Prolonged police questioning, often by teams of interrogators working in relays, characterized approximately half of the cases. The defendant usually was young, relatively uneducated, or of limited intelligence. ${ }^{\mathbf{1 4 7}}$

While the Court's abhorrence of "unconscionable" police conduct had been the leading impulse in this area, at times the Court also had

114 See, e.g., Davis v. North Carolina, 384 U.S. 737, 741 (1966) (notwithstanding the uncontested fact that defendant was of "low mentality" and had been interrogated by the police incommunicado for 16 consecutive days, two state courts and two federal courts nevertheless held the defendant's confessions "voluntary" and thus admissible in evidence against him at trial).

${ }^{145}$ See Stone, supra note 103, at 102-03 ("Given the Court's inability to articulate a clear and predictable definition of 'voluntariness,' the apparent persistence of state courts in utilizing the ambiguity of the concept to validate confessions of doubtful constitutionality, and the resultant burden on its own work load, it seemed inevitable that the Court would seek 'some automatic device by which the potential evils of incommunicado interrogation [could] be controlled'." (quoting W. SCHAEFER, THE SUSPECT AND SOCIETY 10 (1967))).

${ }^{146}$ That is, the Court did not proceed on the basis of a particular "self-evident" comprehensive view - such as the self-consistent principles of Kantian rationality or the empirical axioms of Bentham's utilitarianism. To the extent that the Court's textual interpretation was comprehensive, rather than particularistic, in nature-an option that remains open to PI, but not to the dialect of Scientific Policymaking-its authority nevertheless remained contestable and localized. Thus, the authority was not "self-evident" or universalizable, as Scientific Policymaking would claim.

147 See 3 J. Wigmore, supra note $63, \S 826$ (quoting J. George, Constitutional. Limitations on Evidence in Criminal Cases 90-91 (1966)). 
expressed concern for the criminal suspect herself. In Watts $v$. Indi$a n a,{ }^{148}$ for example, speaking for a plurality of the Court, Justice Frankfurter noted that "[w]hen a suspect speaks because he is overborne, it is immaterial whether he has been subjected to a physical or a mental ordeal. Eventual yielding to questioning under such circumstances is plainly the product of the suction process of interrogation and therefore the reverse of voluntary." 149 To be sure, the source of the principle being expressed here remains obscure. An increasingly evident factor, however, is what Justice Frankfurter describes as the nature of our accusatory system of justice:

Under our system society carries the burden of proving its charge against the accused not out of his own mouth. . . . The requirement of specific charges, . . . the right to assistance of counsel, to be supplied by government when circumstances make it necessary, the duty to advise an accused of his constitutional rights-these are all characteristics of the accusatorial system and manifestations of its demands. ${ }^{180}$

It would take another fifteen years after this statement was made for the Court to locate the textual source of authority for the principle in question. Even then the Court's first steps would be hesitant, betraying both the virtues and concomitant vices of the type of discourse that was taking shape. Nevertheless, the movement toward some unifying, self-consciously interpreted constitutional principle clearly was underway.

In Malloy $v$. Hogan, ${ }^{151}$ for example, the Court explicitly identified the fifth amendment privilege as the "essential mainstay" of our accusatorial system of justice. ${ }^{162}$ Due process jurisprudence was now superseded by the body of case law interpreting the privilege itself. How the Court explained and justified incorporating the privilege into the due process clause of the fourteenth amendment, thus making it applicable to the states, was, however, unsatisfactory.

The question before the Court in Malloy was whether the defendant's refusal to answer questions by state officials about a prior crime was protected by the fifth amendment privilege against self-incrimination. The Connecticut Supreme Court, relying upon Twining v. New

148338 U.S. 49 (1949).

149 Id. at 53.

150 Id. at 54.

151378 U.S. 1 (1964).

152 Id. at 7 ("The shift [to the federal constitutional standard in state cases] reflects recognition that the American system of criminal prosecution is accusatorial, not inquisitorial, and that the Fifth Amendment privilege is its essential mainstay."). 
Jersey, ${ }^{163}$ held that this federal constitutional protection did not extend to the states. ${ }^{184}$

To reach a contrary result, the Court in Malloy needed to come to grips with the holding in Twining. And it did: Twining was expressly overruled. The privilege, said the Malloy majority through Justice Brennan, had become a part of the fourteenth amendment due process clause. ${ }^{105}$ Indeed, the Court now explicitly replaced the ad hoc fundamental fairness approach of due process discourse with an interpretive discourse that focused directly upon the fifth amendment privilege itself. In this way, the Court refused to apply to the states a "watered down" version of this federal right. ${ }^{156}$

Curiously, while Malloy left no doubt that it was specifically interpreting and applying the fifth amendment privilege, rather than putting yet another gloss upon the meaning of "fundamental fairness," the source of authority for the Court's move remained problematic. In fact, as the Court explained, it was not overruling Twining directly. Apparently, Twining had already been at least tacitly overruled by previous cases. ${ }^{157}$ In short, according to Malloy, the shift from evidentiary reliability to due process intuitions of institutional unfairness somehow tells the story of how the fifth amendment privilege gained influence in the

15s 211 U.S. 78 (1908). There, the Court ruled that the fifth amendment privilege may be "a wise and beneficent rule of evidence," $i d$. at 106 , but it was not a fundamental principle of liberty and justice. Accordingly, it could not be deemed a part of the federal due process standard that the fourteenth amendment extends to the states. $I d$. at 105-14; see also Adamson v. California, 332 U.S. 46, 53 (1947) (finding that the fifth amendment privilege is not made effective against state action by the fourteenth amendment), rev'd, 378 U.S. 1 (1964).

1st See Malloy v. Hogan, 150 Conn. 220, 231, 187 A.2d 744, 750 (1963), rev'd, 378 U.S. 1 (1964).

${ }^{185}$ Malloy, 378 U.S. at 3.

158 The forerunner of this change came a year before in the landmark case of Gideon v. Wainwright, 372 U.S. 335 (1963). The Court in Gideon held that the sixth amendment right to counsel was "fundamental and essential to a fair trial"," and thus made obligatory on the states by the fourteenth amendment. Id. at 342 (quoting Betts v. Brady, 316 U.S. 455,465 (1942)). At this stage, however, it was not perfectly clear that the right to counsel that applied to the states was identical to that guaranteed by the sixth amendment. $C f$. id. at 352 (Harlan, J., concurring) (arguing that incorporation of a federal right into the due process clause does not justify "carry[ing] over an entire body of federal law and apply[ing] it in full sweep to the states. Any such concept would disregard the frequently wide disparity between the legitimate interests of the States and of the Federal Government . . .."). In Malloy, however, the incorporation of the fifth amendment was explicitly stated, and the Court expressly rejected a diluted (due process-based) version of the fifth amendment right. Malloy, 378 U.S. at 5-6; see Brennan, The Bill of Rights and the States, 61 N.Y.U. L. REv. 535, 542-44 (1986) (noting that in Malloy, the Court required application of the fifth amendment to the states "with full federal regalia intact").

167 The Court believed that Brown and its progeny had been responsible for the change. See Malloy, 378 U.S. at 6-7. 
federal cases. Moreover, as if this approach to the case law were not disingenuous enough, the Court went on to assert that the same standard had applied in federal prosecutions since 1897. In short, it turns out that Bram had masterminded the whole development:

[T]oday the admissibility of a confession in a state criminal prosecution is tested by the same standard applied in federal prosecutions since 1897, when, in Bram v. United States the Court held that "[i]n criminal trials, in the courts of the United States, wherever a question arises whether a confession is incompetent because not voluntary, the issue is controlled by that portion of the Fifth Amendment to the Constitution of the United States, commanding that no person 'shall be compelled in any criminal case to be a witness against himself"." Under this test . . . the person must not have been compelled to incriminate himself. ${ }^{158}$

The fact that Twining had excluded the fifth amendment privilege nine years after Bram, and that not a single Supreme Court decision since then had relied upon the fifth amendment privilege as justification for its ruling, seems not to have disturbed the Court. According to Justice Brennan, the due process cases had been spreading Bram's message all along. ${ }^{159}$

Simply put, in Malloy, the Court's articulation of a unifying interpretive principle successfully diverted the Court from due process decisionmaking. At the same time, however, Malloy betrayed some of the same features of pseudo-interpretative discourse that informed the due process case law from which it sought release. It is here that we witness one of PI's vices (what is referred to in this Article as a strategy of dominance).

In order to evade the controversy that accompanies significant interpretive shifts in the law (i.e., to escape the burden of providing explanation and persuasive justification for novel readings of inherited texts), the Court instead resorts to a simple expedient. It reads the desired change into the past. In this way, the strain of controversy be-

${ }^{168}$ Id. at 7 (quoting Bram, 168 U.S. at 542 (citation omitted)).

169 In $B r a m$, the Court had ruled that the fact of arrest and that the defendant had been asked to remove his clothing while in police custody sufficed to make the defendant's self-incriminatory statement inadmissible as evidence against him. While unsurprising as a matter of common sense-at least according to the McMahon line, wherein the courts questioned the reliability of defendant's statements based on the "agitation of mind" caused by arrest-in Bram; this outlook upon human nature was offered as an interpretive principle, i.e., as a construction of voluntariness based on the defendant's fifth amendment right against compelled self-incrimination. See Bram, 168 U.S. at 561-65. 
tween past and present is sacrificed to a species of false, disingenuous certainty.

In dissent, Justice Harlan leaves no doubt as to the majority's ploy:

The Court suggests that this consistent line of authority has been undermined by the concurrent development of constitutional doctrine in the areas of coerced confessions and search and seizure. This is post facto reasoning at best. Certainly there has been no intimation until now that Twining has been tacitly overruled.

The majority is simply wrong .... In none of the cases ... . was there anything to suggest that the Fifth Amendment was being made applicable to state proceedings. ${ }^{160}$

While it is evident that the majority in Malloy left undone their main task of explaining and justifying why the fifth amendment privilege against self-incrimination should be included in the fourteenth amendment due process clause and thus be extended to the states, the Court did strew some clues along the way. For example, the Court referred to the "accusatorial" system of justice and to the Court's early recognition, in Boyd $v$. United States, ${ }^{161}$ that the fourth amendment guarantee against unreasonable search and seizure and the fifth amendment privilege seem to "run into each other."162 These observations are richly suggestive, and with further elaboration they could have provided a basis for the general, abstract interpretive framework that the Court needed to supplant the compromised and unpredictable pseudo-interpretative intuitionism of due process discourse. Without more, however, Malloy's use of broad and elusive language, such as its reference to "personal security" and the "free and voluntary" aspect of an accused's

${ }^{160}$ Malloy, 378 U.S. at 17-18 (Harlan, J., dissenting). Justice Harlan goes on to conclude, as he had in his dissenting view in Twining, that the due process clause is well-suited to deal with the admissibility of confessions. According to Harlan, the "community's sense of justice" which, in his view, the due process clause embodies, remains an adequate basis for decisionmaking, without resorting to the majority's tactic of incorporating the Bill of Rights into it "in snatches." Id. at 15-16, 27.

161116 U.S. 616 (1886).

${ }^{162}$ Malloy, 378 U.S. at 9 (citing Mapp v. Ohio, 367 U.S. 643 (1961)). The following is a reflection of the Court's abandonment of evidentiary rules for the sake of constitutional principle: "In thus returning to the Boyd view that the privilege is one of the 'principles of a free government,' Mapp necessarily repudiated the Twining concept of the privilege as a mere rule of evidence "best defended not as an unchangeable principle of universal justice but as a law proved by experience to be expedient'." Id. (citations omitted). 
confession, ${ }^{163}$ provided little substantive guidance as to the actual content and scope of the interpretive principle to which it now laid claim. Escobedo v. Illinois, ${ }^{164}$ decided a week after Malloy, did not improve the situation. Indeed, judging by the confusion in the cases that followed in Escobedo's wake, the principled basis for the Court's interpretive framework seemed even more clouded. In Escobedo, following arrest and while in police custody, the defendant was told by police that the murder case against him was "pretty tight" and that he "might as well admit to this crime." 180 In response, defendant asked to see his attorney. This request was denied. Defendant subsequently incriminated himself, and the statement was later used in evidence against him at trial. Following his conviction for murder, Escobedo appealed, arguing in part that his confession was involuntary. Defendant lost his appeal on the state level, but won before the United States Supreme Court.

Speaking for the majority in Escobedo, Justice Goldberg stated that it was sufficient that the defendant had become the target of a police investigation to make this a "critical stage" in the prosecution. Once the criminal process had "focused upon" Escobedo and sought his confession, it changes from investigatory to accusatory. This shift, the Court held, triggered a defendant's constitutional entitlement to the presence of counsel. The Court reasoned that the need for counsel was no less crucial when the defendant stands alone, in police custody, uninformed of his constitutional rights, than when he faces formal charges at arraignment or during a preliminary hearing. As the Court stated, a defendant's unwitting forfeiture of his rights during pre-indictment interrogation "could certainly affect the whole trial."166 To require the technical fact of indictment, which was the earliest stage at which a defendant's right to counsel attached, ${ }^{167}$ according to Justice Goldberg, "would exalt form over substance." Thus, when defendant Escobedo had become the chief focus of police investigation, he had, "for all practical purposes, already been charged with murder."168

Significantly, in Escobedo, as in Bram, the Court focused upon the accused's state of mind during the interrogation process. Defendant's fear of the incriminating effect of his silence and his sense of futility (i.e., that whether he speaks or not he will still remain the authorities'

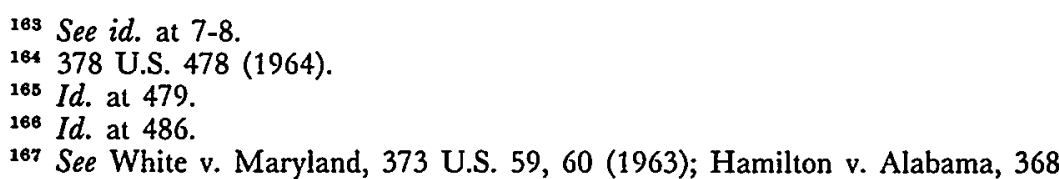
U.S. 52, 53-55 (1961).

${ }^{188}$ Escobedo, 378 U.S. at $485-86$. 
chief suspect), are factors specifically noted by the Court. As in Bram and Malloy, however, it is not McMahon's evidentiary (OGS) concern about truthfulness that is central here. That is, it is not the unreliability of what the defendant might say in the absence of counsel. Rather, it is the fact that she is kept ignorant of her rights, and deprived of the "guiding hand of counsel" when it is most needed, that renders the strain thus placed upon the accused unacceptable to the Court.

However, the Court's constitutional interpretive framework, albeit now bottomed on the sixth amendment right to counsel rather than the fifth amendment right against compelled self-incrimination, upon which Bram and Malloy had relied, offered little practical guidance about the substantive content or scope of its decision. In fact, it raised more questions than it resolved. Rather than unify disparate due process intuitions, it seemed that the "era of confusion"169 the dissenters predicted in Escobedo was at hand. ${ }^{170}$ According to one commentator:

Whether [Escobedo] should be read narrowly or broadly, whether it imposed a duty to warn an accused of his privilege and of his right to counsel, whether its application depended upon a request for counsel, whether its operation was retrospective or only prospective-these and other questions produced much diversity of view among courts, commentators, and officials in their attempt to assess the impact of the decision. ${ }^{171}$

Faced with a chaos hardly better than the one from which it had sought to escape, the Court's next move would be crucial if the discursive shift from judicial intuitions of fairness to principled interpretation was to take hold. When that move came, the debate achieved an almost fevered pitch. That the law of confessions was now defiantly moving along a new path could hardly be gainsaid. It is at this juncture that the controversial dialect of Prudent Interpretation, with its characteristic virtues and vices, may be fruitfully studied.

$1693 \mathrm{~J}$. WIGMORE, supra note $63, \S 826 \mathrm{a}$.

170 Escobedo, 378 U.S. at 494-95, 499 (Stewart, J., dissenting). Notably, at one point-harking back to Justice Harlan's concurrence in Gideon, 372 U.S. 335 (1963) - the Escobedo dissenters linked the court's "principled" interpretation with due process discourse: "[The Court] attempts to find a home for this new and nebulous rule of due process by attaching it to the right to counsel . . ." Escobedo, 378 U.S. at 496 (White, J., dissenting). As for the court's rule itself, i.e., attaching the sixth amendment right to counsel to the accused once he has become a "suspect," from the dissenters' view, it was "amorphous and wholly unworkable" and "stands as an impenetrable barrier to any interrogation once the accused has become a suspect." Id.

$1713 \mathrm{~J}$. WigmoRE, supra note $63, \S 826$ a (footnotes omitted). 
In the landmark decision of Miranda $v$. Arizona, ${ }^{172}$ the Court seemed to consolidate the interpretive efforts of Malloy and Escobedo by providing a self-reflective, abstractly conceived-albeit highly controversial, and at least debatably prudent-reading of the fifth amendment privilege. Interpreting the specific constitutional guarantees embodied within the fifth amendment, the guiding inquiry now became: regardless of wealth, social status, education, or mental endowment, has the dignity, the integrity, the personal inviolability of the individual accused been unduly violated?

In Miranda, the fear of social disorder, outrage at police misconduct, and distrust of the veracity of a particular defendant's statement, yielded in importance to the Court's concern for an abstract interpretive principle and those concrete guidelines that will preserve it. In the opening lines of the majority opinion, Chief Justice Warren left no doubt as to the broad scope of the Court's decision, stating that "the cases before [the Court] raise questions which go to the roots of our concepts of American criminal jurisprudence: the restraints society must observe consistent with the Federal Constitution in prosecuting individuals for crime."173 Recognizing the uncertainty that surrounded Escobedo, ${ }^{174}$ the Court now set out both a unifying interpretive framework and concrete guidelines to direct and edify officials and the lay public alike. In an effort to establish what it understood as the proper balance of power between the state and private individuals, including those accused of crime, the Court self-reflectively encountered the relevant case law and the constitutional text:

Thus we may view the historical development of the privilege as one which groped for the proper scope of gov-

172384 U.S. 436 (1966).

${ }^{173}$ Id. at 439 . The transcript of oral argument is fascinating. See P. KuRLAND \& G. Casper, 63 Landmark Briefs and ARguments of the Supreme Court of THE UnITED States: Constitutional LaW 898 (1975) ("[D]oesn't this problem really affect the basic relationship of the individual and the state? It really goes beyond the administration of justice, and that has been the history of mankind." (remarks of Justice Fortas)).

The oral argument, and the subsequent divisions between the majority and the dissenters in Miranda, vividly capture the utilitarian Scientific Policymaking versus Principled Interpretation split that has characterized the modern debate in this area of the law. Compare id. (remarks of attorney William Siegel, arguing on behalf of the state) ("TT]he immediate objective is to protect society.") with id. at 849-50 (remarks of defense counsel John Flynn, arguing on behalf of defendant Miranda) ("[A] person who is poorly educated, who in essence is mentally abnormal, who is an indigent, . . . at the very least, he is entitled [in an adversary proceeding] to be represented by counsel and to be advised by counsel of his rights under the Fifth Amendment of the Constitution; or, he has no such right.").

${ }^{174}$ Miranda, 384 U.S. at 440-42. 
ernmental power over the citizen. As a "noble principle often transcends its origins," the privilege has come rightfully to be recognized in part as an individual's substantive right, a "right to a private enclave where he may lead a private life. That right is the hallmark of our democracy." . . . All these policies point to one overriding thought: the constitutional foundation underlying the privilege is the respect a government-state or federal-must accord to the dignity and integrity of its citizens. To maintain a "fair state-individual balance," to require the government "to shoulder the entire load,". . . to respect the inviolability of human personality, our accusatory system of criminal justice demands that the government seeking to punish an individual produce the evidence against him by its own independent labors, rather than by the cruel, simple expedient of compelling it from his own mouth. . . . In sum, the privilege is fulfilled only when the person is guaranteed the right "to remain silent unless he chooses to speak in the unfettered exercise of his own will."175

To ensure that the Constitution was not to become a mere "form of words," the Miranda Court now reflectively articulated the founding principle toward which, in its view, the cases had been "groping." That principle embodies the Constitution's safeguarding of individual privacy, integrity, and dignity. ${ }^{178}$ In order to ensure that this principle attains an embodied existence in practice, the Court also articulated the following minimum concrete measures:

Prior to any questioning, the person [in police custody] must be warned that he has a right to remain silent, that any statement he does make may be used as evidence against him, and that he has a right to the presence of an attorney, either retained or appointed. The defendant may waive effectuation of these rights, provided the waiver is made voluntarily, knowingly and intelligently. If, however, he indicates in any manner and at any stage of the process that he wishes to consult with an attorney before speaking there can be no questioning. ${ }^{177}$

176 Id. at 460 (emphasis added) (citations omitted).

${ }^{178}$ Id.; see also id. at 479-80 (rejecting, as antithetical to civilization and the rule of law, the argument that society's need for interrogation outweighs the privilege against self-incrimination).

${ }^{177}$ Id. at 444-45. 
Miranda's presumption of the inherent coerciveness of police custody ${ }^{\mathbf{1 7 8}}$ was not unprecedented. As we have seen, McMahon and its progeny, as well as Bram, reached a similar conclusion before the turn of the century. The meaning of the Court's insight, however, has changed. The reason that procedural safeguards were required under these circumstances was not simply to ensure that evidence obtained from the accused will be reliable, or that the way it was obtained comported with a particular Court's sense of fairness. Even more importantly, the Court now established a general constitutional rule: unwarned statements obtained from the accused while in police custody will not be admissible as evidence against her at trial. ${ }^{179}$ The mere fact of custody - that the accused stands alone before the naked police power of the state-suffices to activate safeguarding principles that the fifth amendment privilege has now been read to embody. According to the majority's interpretation, then, it is in this manner that state power must be checked when the dignity and privacy of the individual accused are at risk.

Given this interpretation, it is no coincidence that the Court stressed the need for a knowing and intelligent waiver of rights. This is especially notable in light of the fact that many of the defendants coming before the Court were either indigent, poorly educated, mentally incompetent, or from marginal social groups, or had experienced a combination of all four of these conditions. ${ }^{180}$ In short, they represented the most vulnerable members of society, those who are most likely to suffer the "badge of intimidation" that police interrogation naturally carries. $^{181}$

178 See id. at 455-56 ("Even without employing brutality . . . the very fact of custodial interrogation exacts a heavy toll on individual liberty and trades on the weakness of individuals.").

179 Id. at 476.

180 Id. at 457 ("The potentiality for compulsion is forcefully apparent, for example, in Miranda, where the indigent Mexican defendant was a seriously disturbed individual with pronounced sexual fantasies, and in Stewart, [384 U.S. 457 (1965),] in which the defendant was an indigent Los Angeles Negro who had dropped out of school in the sixth grade.").

${ }^{181} \mathrm{Id}$. ("It is obvious that such an interrogation environment is created for no purpose other than to subjugate the individual to the will of his examiner. This atmosphere carries its own badge of intimidation." (emphasis added)).

This language resonates with the language of antidiscrimination and other cases that reflect the Court's increased concern for, and solicitude toward, "insular minorities," see, e.g., Carolene Products, 304 U.S. 144, 152 n.4 (1938), and the rights of those who dwell at the margins of society. See, e.g., Jones v. Mayer Co., 392 U.S. 409, 439 (1968) (in the course of applying $\S 1982$ of the Civil Rights Act of 1866 to prohibit discrimination against black homebuyers, the Court noted that the thirteenth amendment "clothed 'Congress with power to pass all laws necessary and proper for aboloishing all badges and incidents of slavery in the United States"." (quoting Civil Rights 
By the same token, the so-called Miranda warnings also served to extricate the courts from the miasma of case-by-case due process decisionmaking. To a certain extent, the new guidelines are fact-independent. The due process concern about police misconduct, which required the courts to assess the totality of circumstances each case presented, now yielded to a twofold factual inquiry that would "give concrete constitutional guidelines for law enforcement agencies and courts to follow."182 The relevant inquiry is the following: was the accused properly informed of her rights and did she waive them in a voluntary, knowing and intelligent manner? Reflecting the sanctity of the individual right at stake, it is the state that bears the heavy burden of proving, by a clear record, that the appropriate warnings were given, understood, and properly waived before the defendant's statements can be used against her. ${ }^{183}$

The controversy that Miranda immediately engendered, and which continues today, should not be ignored. Nevertheless, its significance must be clearly understood. It is not the fact of controversy that is of special concern. Debate on such matters can hardly be avoided, nor should it be. Such debate impels reflectively explained and persuasively justified (as opposed to unreflective, putatively "self-evident") reasons for particular decisional outcomes. Controversy in this sense, then, serves a legitimating function. Accordingly, by questioning the "pru-

Case, 109 U.S. 3, 20 (1883))); see also Bell v. Maryland, 378 U.S. 226, 260 (1964) (Douglas, J., concurring) (noting that the segregation of blacks in restaurants and at lunch counters is a "relic of slavery" and "a badge of second class citizenship"). This linguistic resonance is not serendipity. Rather, it further illuminates the interpretive framework that informs the Miranda Court's encounter with fifth amendment values.

In this respect, one may find in Miranda the implicit idea that the defendant's knowledge (of what is going on) gives the defendant power to freely assent to participate in the interrogation process. Conversely, withholding from the accused knowledge of the legal ramifications of his or her own acts in effect constitutes a form of coercion. It stands to reason that one cannot meaningfully choose whether to speak or remain silent when the significance of that choice remains hidden. To know the possible ramifications and withhold such knowledge from the accused, therefore, might well be viewed as a strategy of (at least passive) deception. And one who has become the object of deception no longer retains the ability meaningfully to assent to what is happening. See Korsgaard, The Right to Lie: Kant on Dealing with Evil, PhIL. \& PUB. AfF., (forthcoming 1987). In this sense, then, the Miranda warnings help to maintain a relationship of respect and equality between the accused and agents of the state. According to the Miranda Court, the fifth amendment protects these human qualities. Miranda, 384 U.S. at 460; see text accompanying note 168; see also Schulhofer, Reconsidering Miranda, 54 U. CHI. L. REV. 435, 445 (1987) ("The policy served by the [fifth] amendment is not limited to preventing inhuman degradation or breaking the will, but extends to all governmental efforts intended to pressure an unwilling individual to assist as a witness in his own prosecution.").

${ }^{182}$ Miranda, 384 U.S. at $441-42$.

${ }^{183}$ Id. at 475 . 
dence" of, as well as the precedential basis for, Miranda's interpretation of the fifth amendment privilege, the dissenters properly engaged in the judicial debate that the Court had initiated. In the process, the merits and drawbacks of competing concerns were explicitly confronted and reflectively assessed. ${ }^{184}$ On the other hand, simply laying claim to putatively "neutral" statistics (e.g., about whether more defendants will go free as a result of Miranda's ruling) or to "self-evident" policy goals, such as the utility of crime control and swift and sure deterrence, cannot alone legitimately decide constitutional controversies. ${ }^{185}$ Simply stated, such nontextual (and decontextualized) analyses cannot do the work of interpretation itself. Unlike commonsensical truths, or the values that preferred social policies embody, interpretations are inherently controversial - not self-evident. They cannot be placed beyond debate.

Thus, while the common sense desire to punish the factually guilty, or the preferred policy goal of deterring others from criminal activity, may serve to test the prudence of a proffered interpretation, it is the prudence of a particular interpretation that is being appraised. Neither common sense nor a particular preferred social policy can adequately do the work of, much less self-reflectively account for, the interpretative process itself. Accordingly, neither may legitimately serve as a decisionmaker's point of departure. ${ }^{\mathbf{1 8 6}}$

184 For example, it is debatable whether, given what the majority regards as the "inherently compelling pressures" of in-custody interrogation, see id. at 467, the safeguards that they propose provided an adequate remedy. As Justice Harlan pointed out, "they do nothing to contain the policeman who is prepared to lie from the start." Id. at 516 (Harlan, J., dissenting).

185 As an indication of the kind of "self-evident" assumptions that may be at work in this regard, witness Justice White's statement: "The most basic function of any government is to provide for the security of the individual and of his property." Id. at 539 (White, J., dissenting). The goals of the criminal process, according to Justice White, are no less obvious. In his view, the function of the criminal law is to remove criminal offenders from "the streets," to ensure their "swift and sure apprehension," and to rehabilitate them. Id. at 540-42 (White, J., dissenting). White not only takes these policy goals for granted, without ever stopping to assess their individual merits or practical efficacy, but he also assumes that counter-intuitive constitutional interpretations, (such as the majority's un-commonsensical understanding of the word "compelled"), obviously constitute a "barrier to the ascertainment of truth." Id. at 542 (White, J., dissenting).

Privileging particular policy goals (such as crime control and deterrence), as well as a particular understanding of "truth" (such as a commonsensical, as opposed to a counter-intuitive or "expert" understanding), amounts to endorsing a particular comprehensive view. As noted above, the view that White espouses seeks to maximize a specifically preferred social policy or "utility." This normative preference, however, like White's preference for (a particular version of) common sense, is no less controversial, or less deserving of reasoned debate, than those normative preferences (such as safeguarding the accused from police pressure as a matter of constitutional entitlement) that White opposes.

${ }^{186}$ In this respect, while Justice White's critique of the majority in Miranda on 
In short, controversy demands reasons at the outset in order to explain and justify the basis for particular judicial outcomes. Without this, decisions remain bottomed on presuppositions that are either reflectively or unreflectively assumed as "self-evident." "Self-evidence," as a point of departure, is not only immune to controversy, (i.e., from its own totalizing perspective), but it also remains closed to the clash of competing values and interests which discordant interpretations engender. Such closure threatens the legitimacy of the judicial decisionmaking process. Of greater interest, then, is not the fact of controversy, but its quality.

Thus, while the Miranda majority's reading of specified texts and their supporting reasons warranted debate, it is not surprising that even the dissenters recognized the "permissibility" of the type of interpretive analysis being used. ${ }^{187}$ In contrast, to the extent that judgment rests upon untested empirical claims and putatively "self-evident" utilitarian premises as its point of departure, the legitimacy of such decisionmaking remains problematic. ${ }^{188}$ Indeed, it is precisely the Miranda majority's freedom from any totalistic endorsement of a particular (non-interpretive) comprehensive view that allowed them to acknowledge, and seek to accommodate, many of the concerns expressed by their opponents. ${ }^{189}$ The ability and willingness strategically to temper interpretive

empirical grounds, see Miranda, 384 U.S. at 533 (White, J., dissenting) ("Judged by any of the standards for empirical investigation utilized in the social sciences the factual basis for the Court's premise is patently inadequate."), represents a valid, albeit empirically dubious stratagem in its own right, the same could not be said were this critical method to be offered as the original basis for a particular judicial outcome.

${ }^{187}$ See id. at 531 (White, J., dissenting) ("[What the majority] has done is to make new law and new public policy in much the same way that it has in the course of interpreting other great clauses of the Constitution. This is what the Court historically has done." (footnote omitted)); id. at 510 (Harlan, J., dissenting) ("The Court's opening contention, that the Fifth Amendment governs police station confessions, is perhaps not an impermissible extension of the law but it has little to commend itself in the present circumstances.").

${ }^{188}$ For example, commenting on the safeguards required by the majority, Justice Clark asserted that "[s]uch a strict constitutional specific inserted at the nerve center of crime detection may well kill the patient." Id. at 500 (Clark, J., dissenting). For his part, Justice Harlan predicted that "[t] ]here can be little doubt that the Court's new code would markedly decrease the number of confessions." Id. at 516 (Harlan, J., dissenting). These dire predictions remained speculative at the time they were made, and subsequent studies have tended to demonstrate that they were wrong. See infra note 202. In any event, they remain outside the domain of interpretive analysis. For this reason, they represent an improper point of departure for judgment. Impartial numbers, if there is such a thing, cannot decide constitutional cases. While an alternative reading of the fifth amendment privilege may preclude the kind of constitutional safeguards the Miranda majority required, see, e.g., Miranda, 384 U.S. at 506-14 (Harlan, J., dissenting), it cannot be gainsaid that the privilege must be read, as well as self-reflectively and persuasively interpreted, at the outset.

${ }^{189}$ See, e.g., Miranda, 384 U.S. at 478 ("Volunteered statements of any kind are 
principle is the hallmark of $\mathrm{PI}{ }^{190}$

If, however, the dialect of PI may eschew narrow dogmatics-by virtue of its taking as its point of departure the uncertain, and thus inevitably controversial meaning of texts, rather than "self-evident" propositions-this is not to say that PI is without significant defects of its own. The tendency to disguise its interpretive rationales in the (false) familiarity of precedent or commonplace language, or to mask what is in effect intuitive discourse by improvising a form of pseudointerpretation, as we saw in the due process cases, gives an embodied existence to the strategies of formal dominance, and the particular kind of tyranny, to which PI discourse is prone.

PI's impulse toward disguise may be understood as an excess of prudence; it reflects the Court's cautious attempt to blunt the appearance of change and, by the same token, the appearance of having exercised unduly antimajoritarian and essentially subjective power. The "strategic" element in interpretive discourse, therefore, reflects the Court's mindfulness of the need to diminish controversy and thus to ensure public and official compliance. In this way, the chief virtue of PI (i.e., taking controversy as its point of departure), is directly generative of its main defect, namely, the fear that excessive controversy might undercut decisional efficacy.

If Miranda's interpretive framework provided reasons with which others may disagree, the Court's strategic concerns focused upon ways in which controversy could be diminished. In its extreme form, this aspect culminates in strategies of formal dominance. Its milder forms, however, do not go this far. Rather, they are attempts to locate points in common with opposing views. The Miranda majority manifested, in varying degrees, both strategic forms. For example, the impulse toward

not barred by the Fifth Amendment and their admissibility is not affected by our holding today.").

This Court, while protecting individual rights, has always given ample latitude to law enforcement agencies in the legitimate exercise of their duties. The limits we have placed on the interrogation process should not constitute an undue interference with a proper system of law enforcement. As we have noted, our decision does not in any way preclude police from carrying out their traditional investigatory functions.

Id. at 481 .

190 Had the majority in Miranda opposed the dissenters' utilitarian policy orientation solely in terms of a "self-evident" intuition concerning a universalizable principle of rational volition, (a view which corresponds to the Kantian version of Scientific Policymaking [SP]), the majority could not have escaped the type of critique due process talk merited. See supra notes 103-39 and accompanying text. Like intuitions of unfairness, or ordinary common sense impressions, intuited universals (whether rationally or empirically derived) are irrebuttable and thus remain outside the scope of reasoned debate. 
disguise may be discerned in the majority's claim that it was not introducing any innovation in the law of confessions. ${ }^{191}$ But the only precedential authority cited in support of this claim was Bram-a case that had been decided over seventy years earlier, and effectively ignored since. $^{192}$

The impulse toward strategic compromise is apparent in the majority's attempt to defuse the dissenters' critical claim that the majority's abstract rights talk, and the concrete measures they authored to safeguard the dignity and autonomy of the accused in police custody, represents a "constitutional straitjacket."193 In response, the majority asserted that "other fully effective means" may be devised apart from the specific procedural guidelines that the Court provided-namely, the socalled Miranda warnings-so long as accused persons are apprised of their right to remain silent and are given a continuous opportunity to exercise that right. ${ }^{184}$ Thus, as if to palliate the dissenters' concern, the majority went on to say: "We encourage Congress and the States to continue their laudable search for increasingly effective ways of protecting the rights of the individual while promoting efficient enforcement of our criminal laws."195

The problem raised here is that the felt need to compromise, to further reciprocal accommodation between opposing views, risks the danger of compromise as a vehicle for self-dissolution, or the evisceration of the Court's interpretive principle. That is, by introducing greater flexibility to avoid the appearance of judicial rigidity, the majority distanced the procedural guidelines that it authored from the constitutional text that was their putative source. To the extent, however, that such guidelines consequently appear to occupy a status less than that which the constitution itself requires, they give rise to a form of sub-constitutional discourse. ${ }^{186}$ Such discourse, however, cannot author-

191 Miranda, 384 U.S. at 442 ("[O]ur holding is not an innovation in our jurisprudence.").

${ }_{182}$ Id. at 461-62.

183 Id. at 545 (White, J., dissenting).

194 Id. at 444.

105 Id. at 467 (emphasis added). Significantly, the majority immediately added the following caveat: "However, unless we are shown other procedures which are at least as effective in apprising accused persons of their right of silence and in assuring a continuous opportunity to exercise it, the following safeguards must be observed." Id.

${ }^{186}$ See Monaghan, The Supreme Court, 1974 Term-Foreword: Constitutional Common Law, 89 HaRv. L. REv. 1, 3, 20-26 (1975) (arguing that much putatively authoritative constitutional interpretation in fact produces a "constitutional common law subject to amendment, modification, or even reversal by Congress"); Schrock, Welsh \& Collins, Interrogational Rights: Reflections on Miranda v. Arizona, $52 \mathrm{~S}$. CAL. L. Rev. 1, 18-19, 48-49 (1978) (attributing continued political antipathy for Miranda to the Court's having created an impression of subconstitutionality by inviting 
ize the intervention of federal courts in state judicial controversies.

Thus, we see here the familiar double-edged quality of strategic ("prudent") discourse: just as Malloy's and Bram's disguise of the past obscured the constitutional advance the Court was really advocating, here too the guise of constitutional "flexibility" would eventually undermine the very constitutional authority (i.e., the foundational principle that the fifth amendment privilege embodies, and the unified interpretive framework that it allows) that the Court had so carefully elaborated. While not destructive of the majority's constitutional grounding-after all, the Court never waivers from its articulation of the minimum constitutional standard that any procedural guideline must meet ${ }^{197}$-its attempt to achieve a strategic compromise elucidates the dangers associated with resorting to prudence as a tactical "dodge": a way of diverting the Court from assuming direct responsibility for outcomes as a matter of explicit textual interpretation.

An additional danger lurks in the attempt to assimilate an opposing vernacular into a discrete criminal procedure dialect. For example, according to the Miranda dissenters and others opposed to the majority's principled discourse, the criminal process proceeds as a "search for truth" by which the factually guilty are "put away" so that society may be protected and so that other delinquents may be effectively deterred from committing crimes in the future. ${ }^{198}$ On this view, then, ensuring a proper balance in state-individual relations does not arise as a legiti-

innovation, and asserting that the Court should have found a constitutional basis for the silence warning in governmental respect for responsible choice); see also Sager, Foreword: State Courts and the Strategic Space Between the Norms and Rules of Constitutional Law, 63 TEx. L. REv. 959, 966 n.19 (1985) (arguing that the judiciary should not give wholesale deference to legislative enactments that infringe on subconstitutional rights).

197 See Miranda, 384 U.S. at 441-42, 444 ("We granted certiorari in these cases .. to give concrete constitutional guidelines for law enforcement agencies and courts to follow. . . . It was necessary in Escobedo, as here, to insure that what was proclaimed in the Constitution had not become a 'form of words' . . . in the hands of government officials." (citations omitted)). The Court also notes: "We deal in our country with rights grounded in a specific requirement of the Fifth Amendment of the Constitution . . . Id. at 489.

Summing up its detailed analysis, the Court said: "The whole thrust of our foregoing discussion demonstrates that the Constitution has prescribed the rights of the individual when confronted with the power of government when it provided in the Fifth Amendment that an individual cannot be compelled to be a witness against himself. That right cannot be abridged." Id. at 479.

${ }^{198}$ See id., 384 U.S. at 537-39 (White, J., dissenting) ("The most basic function of any government is to provide for the security of the individual and his property. . . . These ends of society are served by the criminal laws which for the most part are aimed at the prevention of crime. Without reasonably effective performance of the task of preventing private violence and retaliation, it is idle to talk about human dignity and civilized values." (citation omitted)). 
mate concern within the criminal justice system. Rather than to articulate a constitutional mandate to safeguard the autonomy and dignity of individuals, the utilitarian understanding of the criminal process operates on the basis of other presuppositions about the way people behave (i.e., by calculating pains and pleasures), and the goals society should pursue (i.e., maximizing the aggregate utility, such as security against crime, among the citizenry). To engage in utilitarian discourse, even if it is for the sake of strategic accommodation, is to activate (self-reflectively or not) its discursive presuppositions. For this reason, even "casual" utility talk, including resort to the methodology of utilitarian calculation, risks balancing away constitutionally guaranteed rights. ${ }^{199}$ The presence of such discourse within a different dialect acts like a beachhead: always ready to expand further into enemy territory. ${ }^{200}$

When the Miranda majority claimed that the warnings they enumerated were "an absolute prerequisite in overcoming the inherent pressures of the interrogation atmosphere," 201 the majority seemed to be engaging in the type of empirical analysis upon which utilitarian discourse characteristically relies. Without supporting data, however, this type of claim remains dubious. For example, one may question which particular aspects of police coercion will be effectively diminished by the proffered warnings. Will the mere giving of Miranda warnings stop misbehaving police officers from misbehaving, or will those officials prone to lie simply have one more thing to lie about, namely, whether the warnings were properly waived or whether they were given in the first place? Will more suspects assert their right to silence? Will more seek counsel before speaking? Will they fully realize the nature of the protections now placed at their disposal, to assert or waive as they see fit? As a matter of fact, at the time Miranda was decided these empirical matters remained open. To the extent that they were presumed to be otherwise, and as such used to justify (or, for that matter, to oppose) the majority's ruling, that judgment also can be

199 See Kamisar, Does (Did) (Should) the Exclusionary Rule Rest on a "Principled Basis" Rather Than an "Empirical Proposition"?, 16 CREIGHTON L. REv. 565, 645-67 (1983) (criticizing the Supreme Court for disemboweling the fourth amendment by using utilitarian balancing tests to limit the exclusionary rule); Packer, Two Models of the Criminal Process, 113 U. PA. L. REv. 1, 31-33 (1964) (setting out the standards that a crime control model, purified of due process concerns, would apply to interrogations); see also Damaska, supra note 36, at 574-77 (suggesting that Packer's due process model is not an alternative model of the criminal justice system, but rather a label for individual rights concerns, and as such is in unresolvable tension with prosecutorial efficiency).

200 And it is here where the opponents of Miranda will make their most effective inroad on that decision. See infra text following note 240.

${ }^{201}$ Miranda, 384 U.S. at 468. 


\section{questioned. ${ }^{202}$}

In short, as a matter of strategy, the Miranda majority may have sought to preempt the dissenters on the latter's discursive home ground. The cost of such a tactic, however, reckoned by the dangers associated with speaking and thinking in the language of utilitarian SP, warrants careful noting. On the other hand, while the majority may have compromised principle in a debatably prudent effort to ensure compliance, their foray into goal-oriented, empirical (SP-utility) discourse nevertheless remained a strategy of accommodation. Thus, while the majority admittedly hypothesized, as an untested empirical matter, that their ruling would not unduly hamper crime control objectives, their primary rationale-their point of departure-remained a matter of interpretive principle, not empirical data.

If, in the aftermath of Miranda, some police officers continued to disregard the dignity of the accused by failing to comply with the requisite constitutional safeguards, at least the context was well settled: the officer would be violating a constitutional norm. In other words, the Court in Miranda was no longer offering conflicting intuitions of judicial conscience or conflicting common sense notions of truth and manifest criminality. Rather, the Court had assumed a leading role as a source of public edification. ${ }^{203}$ Officials and citizens alike were being informed of those constitutional protections to which all citizens are entitled, and all officials are obliged to respect. In short, the dialect of Prudent Interpretation, which we see operating in the Miranda majority was not simply, or primarily, predicting outcomes or systematically

202 See, e.g., Project, Interrogations in New Haven: The Impact of Miranda, 76 YALE L.J. 1519, 1563, 1565-67 (1967) (concluding that warnings had little impact on suspects' behavior: "No support was found for the claim that warnings reduce the amount of 'talking'."); Seeburger \& Wettick, Miranda in Pittsburgh-A Statistical Study, 29 U. PrTT. L. REv. 1, 9-20 (1967) (showing some decrease in police procurement of confessions following compliance with Miranda, ranging from $2 \%$ for rape suspects to $46 \%$ for homicide suspects, but no significant drop in conviction rate); see also Medalie, Zeitz \& Alexander, Custodial Police Interrogation in Our Nation's Capital: The Attempt to Implement Miranda, $66 \mathrm{MICH}$. L. REv. 1347, 1370-79 (1968) (finding that many suspects misunderstand, disbelieve, or ignore the warnings).

${ }^{203}$ See White, Rhetoric and Law: The Arts of Cultural and Communal Life, in Heracles' Bow, supra note 18, at 28, 40-45 (noting that the way a court talks about self, others, and social institutions constitutes a rhetorical community and establishes a coherent public vision of the Constitution and the values such discourse activates); White, The Fourth Amendment as a Way of Talking About People: A Study of Robinson and Matlock, 1974 SuP. CT. REv. 165, 167 n.3 [hereinafter White, The Fourth Amendment] (same); see also Olmstead v. United States, 277 U.S. 438,485 (1928) (Brandeis, J., dissenting) ("Our Government is the potent, the omnipresent teacher."), quoted with approval in Miranda, 384 U.S. at 480; Linde, Judges, Critics, and the Realist Tradition, 82 YALE L.J. 227, 238-44 (1972) (arguing that judicial use of realism is generally counterproductive for the practical success of the Court's constitutional holdings). 
implementing particular social policy goals. It was self-reflectively shaping the culture through critical textual (re)interpretation. As James B. White might put it, the Court was writing a "drama of public significance."204 The language it used

should be regarded as much more than a technical or professional language, to be evaluated by its clarity, precision and efficacy. It is also a social and intellectual force of enormous significance, a critical expression of value and attitude in some ways more important to the quality of the community it defines than the particular decisions taken under it. ${ }^{205}$

When dialogic choices remain unwitting, the commingling of incommensurate forms of discourse, the tensions that come of juxtaposing irreconcilable presuppositions, and the risks of delegitimation that accompany unrestrained dialogic dominance, remain unchecked. It is as if each speaker were being held within a space defined and informed by a particular narrative construct. Each looks out from her own window upon the world; each faces the different realities of self, others, and social institutions allowed by each discrete window of discourse.

This image of partitioned perspectives helps to explain why the level of outrage among the four dissenters in Miranda was so high. The answer comes, at least in part, from the majority's commitment to a counter-intuitive, abstract constitutional principle. To the dissenters, the majority's new world of rights discourse was more than passing strange-it was incoherent. This is due, in part, to the majority's laying bare and shattering of basic OCS presuppositions. It is the overthrow of empirical common sense, which Bram attempted but failed to achieve, which due process discourse left dangling for thirty years in the crosswinds of its own pseudo-interpretive (hybrid) version of common sense, and which Miranda decisively proclaimed (on the heels of Malloy and Escobedo) that seems to have bewildered the dissenters. In this sense, the vehemence of the dissenting opinions should not be surprising. What we witness here are the aftershocks of a revolution in the way jurists think and talk about confessions law. Justice White's observation reflects the newly marginalized ordinary common sense viewpoint:

Common sense informs us to the contrary. While one may say the response was "involuntary" in the sense the question provoked or was the occasion for the response and thus the defendant was induced to speak out when he might have re-

204 White, The Fourth Amendment, supra note 203, at 167.

208 Id. at 167-68. 
mained silent if not arrested and not questioned, it is patently unsound to say the response is compelled..$^{206}$

The majority's procedural guidelines, according to Justice White, "make very little sense."207 To him, asking the accused whether or not she committed a crime is not only not immoral or unconstitutional, but might well prove beneficial, by providing the suspect with "psychological relief" that would "enhance the prospects of rehabilitation."

In this debate between majority and dissent, we see the recapitulation of the early debate that surrounded the fifth amendment privilege itself. Why should the factually guilty be allowed to hide behind legal technicalities? queried Bentham and Wigmore. ${ }^{208}$ Of what relevance to the jury's quest for the truth is the "constable's blunder?" queried Cardozo. ${ }^{210}$ In short, the concrete particularity of OCS hits up against the barrier of abstraction built by constitutional rights talk. The impact is thoroughly dazzling. How can the "quality of a nation's civilization" "211 depend upon such counter-intuitive notions? How can this possibly comport with the basic need to quickly and efficiently deter crime? Thus, the dissenters are left vexed and confounded at having been shunted to the margins of discourse. To them, common sense itself had been banished. And so it had. To be sure, its revival after the Miranda "debacle" would now need to be achieved on grounds other than the self-evident assumptions upon which OCS unreflectively relied. During the Burger years, the Court's self-conscious preference for a crime control policy would lead the Court away from Miranda's unified interpretive framework. And, as we shall see, it is a path the Rehnquist Court seems prepared to broaden. ${ }^{212}$

During the late 1960s and early 1970s, however, the Court's new way of thinking and talking about confessions began to permeate the

${ }^{208}$ Miranda, 384 U.S. at 534 (White, J., dissenting); cf. Michigan v. Tucker, 417 U.S. 433, 444-45 (1973) (distinguishing actual physical compulsion from compulsion that arises from the failure to make available the full measure of procedural safeguards associated with the privilege against compulsory self-incrimination recognized by Miranda).

${ }^{207}$ Miranda, 384 U.S. at 536 (White, J., dissenting).

${ }^{208}$ Id. at 538 (White, J., dissenting).

208 See J. BenTHAM, supra note 49, at 558-59 ("[A]ll precautions which are not absolutely necessary for the protection of innocence, offer a dangerous protection to crime."); 8 J. Wigmore, Evidence in TRIALS at Common Law § 2252 (J. McNaughton rev. ed. 1961) ("The privilege at common law did not apply to police interrogations, and ... it is doubtful that there is sufficient reason today to distort the privilege to cover this situation.").

${ }_{210}^{21}$ See People v. Defore, 242 N.Y. 13, 21, 150 N.E. 585, 587 (1926).

211 Miranda, 384 U.S. at 480 (quoting Schaefer, Federalism and State Criminal

Procedure, 70 HaRv. L. Rev. 1, 26 (1956)).

${ }^{212} C f$. infra notes $253-70$ and accompanying text. 
legal culture. ${ }^{213}$ The new rights talk also began to change the way courts talked about defendant's pretrial silence. In fact, many commentators and some courts went so far as to suggest that with Miranda and its progeny the common law "tacit admissions" doctrine had run its course. ${ }^{214}$ Indeed, in many cases, the same regard for safeguarding the accused from governmental overreaching seemed to govern, whether silence or speech was at issue. ${ }^{215}$ In light of Miranda's interpretive framework, this view makes sense. If the Court was concerned with preserving the defendant's dignity and privacy, and if only a knowing, intelligent, and voluntary waiver of her fifth amendment privilege entitles the state to use evidence obtained from the defendant while in custody, obliging defendant to explain her silence at trial, or otherwise "penalizing" her for exercising her right not to speak, seems similarly unheedful of the Court's dignity and privacy concerns.

Curiously, however, in the aftermath of Miranda, both ordinary common sense evidentiary talk and the intuitive fairness concerns that characterize the courts' due process discourse have kept their vitality in this area of the law. United States $v$. Hale $e^{216}$ is a case in point. Following his arrest for robbery, Hale was advised of his Miranda rights. He remained silent in response to a police officer's query concerning the source of the money that was discovered in his possession. At trial, Hale testified that the money was from his estranged wife. In an effort to impeach this account, the prosecutor asked why defendant had not offered this exculpatory evidence to police when he had had the opportunity to do so after his arrest. ${ }^{217}$ The trial court instructed the jury to disregard the exchange but refused to declare a mistrial. ${ }^{218}$

On appeal, defendant's conviction was overturned because of the

213 See 3 J. Wrgmore, supra note 63, $\$ 826$ a (collection of various phrasings of defendant's right to counsel). In the years following Miranda, the context in which its procedural safeguards were required extended from police interrogation in the station house to questioning the accused in a jail cell, see Mathis v. United States, 391 U.S. 1 (1968), and even in his own home, see Orozco v. Texas, 394 U.S. 324 (1969).

214 See, e.g., Gamble, supra note 81 , at 31-43 (discussing psychological unreliability of the tacit admission rule and its constitutionality after Miranda); see also Miranda, 384 U.S. at $468 \mathrm{n} .37$ (stating in dictum that, "[i]n accord with our decision today, it is impermissible to penalize an individual for exercising his Fifth Amendment privilege when he is under police custodial interrogation. The prosecution may not, therefore, use at trial the fact that he stood mute or claimed his privilege in the face of accusation.").

${ }^{215}$ See C. MCCoRMICK, supra note $101, \S 160$ (discussing cases in which silence after arrest was used to impeach witnesses); $2 \mathrm{H}$. UNDERHILl, CRIMINal Evidence $\S 378$ n.67, § 379 n.79 (5th ed. cum. supp. 1978).

${ }_{216}^{216} 422$ U.S. 171 (1975). See generally $3 \mathrm{~J}$. WIGMORE, supra note 63, § 821 (discussing due process aspects of silence cases).

${ }_{217}$ See Hale, 422 U.S. at 174.

218 See id. at 172-73. 
prosecutor's comment. ${ }^{218}$ The Supreme Court affirmed. ${ }^{220}$ However, contrary to what one might expect in the aftermath of Griffin $v$. Californi $a^{221}$ and Miranda, the Court did not advance a constitutional rationale. Rather, Justice Marshall relied upon traditional rules of evidence.

According to the traditional rule, impeachment with a prior inconsistent statement requires an "inconsistency," 222 plus, one would imagine, a "statement"-although Marshall left the supposed equivalence of speech and silence implicit. Absent inconsistency between the defendant's pretrial silence and his trial testimony, Marshall explained, silence is inadmissible because it lacks sufficient probative value. ${ }^{223}$ With this traditional analysis in hand, Marshall concluded that, as a matter of ordinary common sense, it was "natural" under the circumstances for defendant to have remained silent after arrest. For one thing, Marshall noted, defendant had been told by police that he had the right to remain silent. Moreover, given the "emotional and confusing" conditions at arrest and during custodial interrogation, the "suspect" may have felt there was no need to reply. ${ }^{224}$

Thus, reaching back to, but without citing, the early McMahon school of common sense, Marshall concluded that "silence at the time of arrest generally [is] not very probative of a defendant's credibility."225 Marshall added that there is also the danger that "the jury is likely to assign much more weight to the defendant's previous silence than is warranted." 2228

What is curious here is the generality of Marshall's observation. He seems to be concluding that defendants may always have good reason not to speak to authorities while in police custody, and thus their silence may never be probative of guilt. Here, we see the hallmark of OCS dominance: the rule of "self-evident" truths about how people may be expected to behave. Note that, once again, the judiciary assumes that judges are better equipped than twelve lay people to articu-

${ }^{219}$ See United States v. Anderson, 498 F.2d 1038, $1041-45$ (D.C. Cir. 1974) (relying on Miranda constitutional principles), affd sub nom. United States v. Hale, 422 U.S. 171 (1975).

${ }^{220}$ See Hale, 422 U.S. at 173.

221380 U.S. 609, 614 (1965) (Prosecutorial comment on defendant's silence at trial "is a penalty imposed by courts for exercising a constitutional privilege. It cuts down on the privilege by making its assertion costly.").

222 See 3A J. WIGMORE, supra note 63, § 1040 (discussing self-contradiction).

${ }^{223}$ See Hale, 422 U.S. at 176-77.

224 Id. at 177.

${ }^{225}$ Id. at 180 (emphasis added).

228 Id. 
late a common sense perspective. ${ }^{227}$

Ironically enough, Marshall converts Miranda's talk about the inherent coerciveness of police custody from a springboard to fifth amendment analysis to a return to empirical OCS talk. Compounding the irony, in a concurring opinion, Justice White, after recalling his opposition to Miranda's constitutional rights talk, a form of discourse that Marshall supported in Miranda, now finds himself unable to accept Marshall's OCS perspective-the very perspective that framed, at least in part, White's dissent in Miranda. White concurs in Hale because he feels it is necessary to invoke constitutional discourse. Foreshadowing the future course of the Court, however, it is not individual rights talk that White enlists. Instead, he reverts back to due process talk:

[I]t seems to me that it does not comport with due process to permit the prosecution during the trial to call attention to his silence at the time of arrest and to insist that because he did not speak about the facts of the case at that time, as he was told he need not do, an unfavorable inference might be drawn as to the truth of his trial testimony. ${ }^{228}$

In other words, White is caught in the paradoxical position of arguing on the one hand that custodial interrogation is not inherently coercive and thus does not trigger the fifth amendment privilege against compelled self-incrimination, ${ }^{229}$ while maintaining on the other hand that using silence after Miranda warnings have been given is fundamentally unfair. How he can accept the precedential authority of $\mathrm{Mi}$ randa without also crediting its conclusion regarding inherent coerciveness, and without at least tacitly recognizing Marshall's common sense concern about the effect of such pressures upon defendant Hale, remains unclear. In this regard, Chief Justice Burger's concurrence is more to the point. ${ }^{230}$

If White belabored Marshall's OCS account from without, by reintroducing due process fairness talk in place of the majority's ordinary expectations about how people behave, Burger belabored the Marshall opinion from within. According to Burger, it makes no sense ("there is not a scintilla of empirical data"231) to conclude that innocent suspects

${ }^{227}$ It is notable that after having bottomed his analysis in Hale on evidentiary (OCS) grounds, Justice Marshall paradoxically points out in a footnote "grave constitutional overtones" which allow this matter to be removed from the discretion of the trial judge and subjected to Supreme Court review. Id. at 180 n.7.

${ }_{228}$ Id. at 182-83 (White, J., concurring).

${ }^{229}$ See Miranda, 384 U.S. at 533-34.

230 See Hale, 422 U.S. at 181-82 (Burger, C.J., concurring).

${ }^{231}$ Id. at 181 (Burger, C.J., concurring). 
are either more or less likely to remain silent after arrest than those who are guilty. ${ }^{232}$ In this way, Burger undermined Marshall's empirical OCS assumptions on their own ground. He also graphically showed precisely what the McMahon and Teachout cases had already taught: namely, that unreflective and unsystematic (in other words, "commonsensical") discourse naturally repels consistency or predictability of judicial outcomes. ${ }^{233}$

Thus, in the aftermath of the Court's movement toward a new and unified individual rights-oriented interpretive framework, cases like Griffin, Hale and Miranda leave us with a curious admixture of discrete and incommensurate criminal procedure dialects. ${ }^{234}$ Statements before trial remained cloaked in the constitutional protections provided by the fifth amendment privilege against compelled self-incrimination. The cases involving pretrial silence, however, exhibited the same conflict that predated the Miranda revolution. Indeed, the situation here had grown more complex, for we now enter a realm in which the three dialects of criminal procedure-including both forms of OGS discourse (i.e., ordinary expectations about how people behave and what that behavior signifies, and judicial intuitions of fundamental fairness) - directly vie with one another for ascendancy.

Nor has OCS quietly submitted in the mainstream of confessions law to the dominance of PI's counter-intuitive interpretive principles. In the years ahead, from its place of banishment at the margins of legal discourse, OCS will increasingly gain back its own. Furthermore, it will be the Miranda majority's strategic offering to the opposition, like some unwittingly spawned Trojan horse, that will provide the means of achieving PI's fall from ascendancy. Formal strategies of dominance and deception will recur: this time, however, in the service of yet another way of thinking and talking about confessions and silence. More specifically, we will now see the comprehensive policy of crime control, with its emphasis upon fast and efficient deterrence in quest of the fac-

232 See id. ("It is no more accurate than to say, for example, that the innocent rather than the guilty, are the first to protest their innocence. There is simply no basis for declaring a generalized probability one way or the other.").

${ }^{233}$ Curiously, Justice Burger also seized this opportunity to similarly repudiate Justice Harlan's opinion for the majority in Grunewald v. United States, 353 U.S. 391 (1957). In that case, Justice Harlan found that when participating in a secret proceeding, such as a grand jury, the defendant is more likely to remain silent than in open court. Id. at 422-23. According to Burger, this observation "has no basis in human experience." Hale, 422 U.S. at 181 (Burger, C.J., concurring). Justice Burger's goal here, however, is unclear. On the one hand, he approves of the Hale majority's avoidance of constitutional discourse. Yet, in his own insistence upon the truths of ordinary human experience, he shows up the inevitably irreconcilable conflict that opposing OCS views generate.

234 See infra note 403. 
tually guilty, gain in influence. Its discrete dialect, what this Article refers to as the utilitarian mode of Scientific Policymaking, will concomitantly move closer towards dialogic dominance.

In this way, OCS will appear to reclaim the Supreme Court's discourse about confessions and silence-but underlying the court's textual surface, OCS's service to SP-utility will remain paramount. Thus, the gain will go to the experts, the reckoners of costs and benefits, not to the lay public in whose name (albeit in name only) the ascendancy of SP-utility will, at least in part, be claimed. The rise of SP-utility, and the dominance it achieves over other criminal procedure dialects and their respective dialogic communities, is the tale the cases next will tell.

\section{Scientific Policymaking and the Utilitarian Cost/Benefit} Calculus: Criminal Process as Crime Control Ideology

This Article has argued that in the domain of criminal procedure the meanings of words conform to those narrative and normative designs that configure three discrete dialects of judicial decisionmaking. Each dialect acts as a unique lens upon the world: through it particular factual and normative meanings make sense, others do not. When unreflective discourse prevails, such as common sense, it is as if the lens has become the world, rather than the portal through which it takes shape. With each changing image or intuition, the world is renewed. Such is the totalizing power of common sense's conflicting "self-evident" truths. When totalizing truths are reflective, however, and are arranged to reflect a systematic comprehensiveness, the cinematic complexity of the common sense world gives way to a greater constancy: the constancy of unwavering "self-evident" axioms or foundational rational principles. Put differently, when particular axiomatic presuppositions predominate within a comprehensive model, the dialect of Scientific Policymaking holds sway. With the dominance of this dialect, Orwell's insight reverberates anew: to conquer the dictionary is the greatest victory of all. ${ }^{235}$

During the Burger Court era, familiar meanings were strained through a new comprehensive dialect, namely, the utilitarian version of the dialect this Article refers to as Scientific Policymaking. From within this dialogic perspective, Miranda's interpretive framework was done over, translated into the lexicon of crime control ideology.

With Miranda and its progeny, the presumption of compulsion inherent in custodial interrogation freed the courts from case-by-case

238 See G. ORwELL, 1984, 46-47 (Signet ed. 1961) ("In the end we shall make thoughtcrime literally impossible, because there will be no words in which to express it. . . The Revolution will be complete when the language is perfect."). 
analysis that due process talk had spawned. Unruly facts, and the spoils of a swearing contest between the accused and police about events that had transpired behind closed police doors, bowed to an abstract interpretive principle that grew out of the Court's current encounter with the fifth amendment privilege. Based upon this new reading of the privilege, the Miranda Court designed constitutional safeguards to check the risk of governmental overreaching and to protect the dignity and autonomy of the individual accused. While Miranda diverted the courts from ad hoc, intuitionistic decisionmaking, the decision carried a price.

If empirical contestability and normative subjectivity are the bane of unreflective and unsystematic (observational or intuitive) common sense decisionmaking, ${ }^{236}$ the tense compromise between interpretive principle and particularized (context-sensitive) justice represents the bane of the reflective, but unsystematic, dialect of Prudent Interpretation (PI). As an example of the latter, the preceding Section noted the Miranda Court's effort to loosen what others called a "constitutional straitjacket." In doing so, the Court risked turning compromise from prudent "accommodation" into the evisceration of interpretive principle. Yet the alternative, namely to ignore the risk of doing injustice in the particular case-a risk that accompanies abstract, principled discourse-poses a danger that is no less formidable. While abstract principle may bring stability and predictability to judicial decisionmaking, it is prone to turning hard and brittle. Thus, rising to the level of abstract generalization risks forcing the Court into early self-reversal. This can occur when unforeseen circumstances require that the "hardness" of formal principle fall to an overriding sense of the "right" outcome in a particular concrete conflict ${ }^{237}$ or when a new set of values does battle with an extant rival. For its part, however, prudent accommodation remains a source of uncertainty in the law. By introducing doubt about the actual ratio decidendi of a particular decision, prudent accommodation diminishes a decision's precedential value as a basis for predicting future outcomes.

The Burger Court was quick to recognize Miranda's vulnerability

236 This Section contends that, to an even more dangerous degree, such contestability and subjectivity represent the vice of Scientific Policymaking, which is that dialect's systematic totalization of premises that are essentially contestable, but which Scientific Policymakers hold out to be "self-evident."

${ }^{237}$ This is what Llewellyn has referred to as "fireside equities" or "situation sense." See K. Llewfll.yn, The Common Law Tradition 121-57 (1960) (asserting that appellate courts have been willing to use their own "horse sense" in dealing with situations when fairness seemed to dictate some divergence from the existing rules of law). 
to attack on the basis of both of these PI vices, that is, the "hardness" of its abstract principle and the uncertainty that surrounded the Court's "prudent" efforts to accommodate principle with other interests or values. During the early 1970 s, the Court regularly transformed the lexicon of interpretive principle into a new and comprehensive dialect through a process of systematic translation. As a result, the high ground staked out by Miranda and its progeny was gradually retaken by a cost/benefit calculus in the service of crime control ideology. Familiar cases lost their former meanings: victims of a comprehensive view in which individual rights talk strained coherence.

For those adhering to its dictates, crime control ideology offered a "self-evident" point of departure: the felt need to calculate the utility of deterring crime in order to maximize social security. Notably, deterrence obtains here a specific meaning: the swift and sure punishment of the factually guilty. Other possible meanings for the term, such as controlling police activity for the sake of a different "utility"-maximizing individual dignity, even if it means freeing the "factually guilty"-do not occur within the lexicon of the crime control advocates. Indeed, the "self-evident" meaning of this crucial and deeply controversial term within the Burger Court's crime control lexicon exhibits the underlying comprehensive view that it serves. ${ }^{238}$

By the early 1970s, the Court had imposed an even more stringent analysis in the guise of attacking the reputed inflexibility of Miranda's interpretive principle. The Court achieved this by engaging in a form of law talk that is closed at the outset and intent on systematically remaking the universe in its own image. Such is the nature of SP. This discourse, operating here in its utilitarian, as opposed to its Kantian, modality ("SP-utility"), is "ideological" in the sense that it operates "behind our backs, rather than appearing as a theme before our eyes."239 It embodies a core of principles or presuppositions whose validity is putatively "self-evident" and thus requires no explanation or persuasive justification. These originary presuppositions are built into the type of discourse that the decisionmaker engages; they proceed from the system that the discourse embodies rather than tell us about it. In this way, they provide certainty as a point of departure. Such certainty,

238 The fact that the Burger Court gave short shrift to alternative interpretations of "deterrence," see infra text following note 238, although it could not ignore police deterrence altogether, see infra text following note 239, reflects what this Article refers to as ideological normative preference. The apparent neutrality of the term "deterrence," with its superficial appeal as the object of a quasi-mathematical calculative method, masks its underlying controversiality, which is to say, its subjective (sub rosa) privileging of preferred norms.

${ }_{239}$ P. Ricoeur, Hermeneutics and the Human Sciences 227 (1981). 
however, is not only suspect, it also carries a consequential toll. That which lies outside SP's comprehensive system remains incoherent: either unworthy of discourse or existing as mere raw material for inclusion (via systematic translation) into an already defined realm of "possible" meanings. As a result, the dynamic of debate closes down, silenced by the tyranny of ideological, or "incontrovertible," presuppositions.

The first clear sign that Miranda's interpretive mode of discourse was being eroded came only five years after it was decided. In Harris v. New York, ${ }^{240}$ the Burger Court began to give voice to its crime control ideology. In that case, the question the Court faced was whether a defendant's statement, taken while in police custody without the benefit of Miranda warnings, could be used to impeach the defendant's testimony on direct examination at trial. By a majority of one vote, the Court ruled that the Miranda decision did not intend to exclude this type of evidence. Faced with Miranda's explicit statement to the contrary, Chief Justice Burger, writing for the majority, dismissed it as dictum. ${ }^{241}$

Of particular interest is the manner in which this limitation upon the expressly stated intent of Miranda was achieved. Burger stated: "It does not follow from Miranda that evidence inadmissible against an accused in the prosecution's case in chief is barred for all purposes, provided of course that the trustworthiness of the evidence satisfies legal standards." 242 Curiously, the Court has interjected pre-Miranda (indeed, pre-Brown) discourse about confessions, for "untrustworthiness" is the mainstay of evidentiary (OCS) analysis. It harks back to the period before Brown, when common sense reigned supreme. Indeed, in Harris, Chief Justice Burger relied upon common sense. Once the defendant took the witness stand, Burger noted, his obligation was "to speak truthfully and accurately, and the prosecution here did no more than utilize the traditional truth-testing devices of the adversary process."243

Surely, however, there is more at stake here. The issue is whether concededly illegal evidence can be used against the accused. While it is true, as Burger recounted, that "[p]etitioner makes no claim that the statements made to the police were coerced or involuntary,"244 this

240401 U.S. 222 (1971).

${ }^{241}$ See id. at 224 (According to the Chief Justice, the issue was "not at all necessary to the Court's holding and cannot be regarded as controlling.").

242 Id.

243 Id. at 225.

244 Id. at 224. 
misses the essential point of Miranda. The Miranda Court explicitly stated that when the accused stands alone before the vastly superior police power of the state within the closed confines of in-custody interrogation, that environment should be considered inherently coercive. ${ }^{245}$ It is this presumption that dictates the necessity of the Miranda warnings and makes considerations of "trustworthiness" extraneous. Moreover, neither Miranda and its progeny nor even the earlier due process cases questioned the truthfulness of the statements at issue. The question of truthfulness was consciously superseded by other concerns: in Brown, the concern with unfair police methods that were used to extract confessions; in Miranda, the concern with protecting the autonomy and dignity of the individual from the inherently compelling influence of custodial interrogation. For Chief Justice Burger in Harris, however, it is neither institutional fairness nor individual rights that rules. Rather, it is the truth value of the illegal confession that justifies its use at trial: "The shield provided by Miranda cannot be perverted into a license to use perjury by way of a defense, free from the risk of confrontation with prior inconsistent utterances."246

Ruled by a common sense concern with truth, the Chief Justice can see no reason to obstruct the adversary process from taking its "natural" course: namely, the search for truth. By effecting a discursive shift back to evidentiary trustworthiness talk, the Court dodged both Brown's initial and Miranda's subsequent constitutionalization of state confessions. Given the Court's renewed championing (sub voce) of the common sense perspective, it is only natural that the lay jury, the principal community of common sense discourse, would become the main beneficiary. In this sense, it is not surprising to see the Court touting the "benefits" of impeachment, proclaiming that its role as a "valuable aid to the jury ... should not be lost . . . ."247

It was not merely a return to the common sense evidentiary perspective that Chief Justice Burger achieved in Harris. Even more significantly, he began turning from constitutional interpretation to the language of crime control ideology. This occurs in two places within the Harris Court's brief opinion. First, as already noted, Burger sidesteps Miranda's presumption of compulsion when he observes that no claim of involuntariness had been asserted by Harris. Second, Burger translates Miranda's reflective, but unsystematic mode of discourse (i.e., the concretely contextualized, principled textual discourse of PI), into the reflective and systematic rhetoric of crime control. In the crime

245 See Miranda, 384 U.S. at 457-58.

248 Harris, 401 U.S. at 226.

247 Id. at 225. 
control ideology, a different understanding of self, others and social institutions prevails. In place of a universe in which official threats to the self-reflectively valued autonomy of the accused trigger constitutional protection, a situation exists in which the individual is seen as a calculator of self-interest. Faced with the unpleasurable consequences that will stem from a particular act, the individual will choose to act otherwise. On this premise, behavior, at least to some extent, can be controlled. Armed with a sense of preferred ends, and given the "calculating" nature of humans, decisions can be structured so as to guide individual action toward the realization of those ends.

With crime control as the dominant, "self-evidently" preferred, policy of the criminal process, deterring the factually guilty offender becomes the judiciary's primary objective. According to this view, specific judicial rulings may be directed at those calculating individuals who either have committed, or may contemplate committing, impermissible acts. Successful control of their behavior represents the achievement of the Court's preferred social policy goal. ${ }^{248}$ Protecting her "constitutionally enshrined" dignity must now find its value within this new comprehensive lexicon.

With this lexicon in mind, let us observe more closely the Harris translation of Miranda's interpretive principle. To the extent that $\mathrm{Mi}$ randa retains any meaning at all in the crime control universe, it is as a source of guidelines for police behavior. This understanding of $\mathrm{Mi}$ randa in turn presupposes an overriding goal: presumably, for it remains unarticulated in Harris, that goal is for police to act within the constraints of the law. As Chief Justice Burger noted: "Assuming that the exclusionary rule has a deterrent effect on proscribed police conduct, sufficient deterrence flows when the evidence in question is made unavailable to the prosecution in its case in chief."

This is a masterly translation when examined in the full context of the Harris decision. Since "proscribed police conduct" seems to refer to illegal conduct, it is reasonable to assume that Miranda's aim was to keep police behavior lawful. Harris, however, involved concededly illegal police conduct: the procurement of evidence without full Miranda warnings. Yet, it is not this illegality that most concerns the Court. Rather, it is deterrence. Indeed, the Court now focuses upon the kind of deterrence at issue. Even if improper police behavior took place, and

248 See, e.g., Michigan v. Tucker, 417 U.S. 433, 450-51 (1974) (considering "society's interest in the effective prosecution of criminals"); Miranda, 384 U.S. at 539-542 (White, J., dissenting) (security of person and property are served by criminal laws "which for the most part are aimed at the prevention of crime").

249 Harris, 401 U.S. at 225. 
there is no dispute in Harris that it had, the question becomes what good will it serve to exclude the evidence. The answer is given in the terms in which the question is posed: the good to be served is to be judged by the extent to which the "self-evidently" preferred goal of deterrence is achieved.

The terms of the Court's equation may now be read back. The purpose of evidentiary exclusion rules is to deter bad police conduct. In Harris, however, the police did not coerce the defendant; they simply failed to inform him of one of the requisite Miranda warnings. The Court questions whether this omission is something that will be "deterred" if the illegal evidence is excluded in the case. The Court answers no, finding that the goal of deterrence will not be served and, thus, the evidence need not be excluded.

The terms in which the Court's equation is balanced in Harris warrant close scrutiny. On one side, there are the unquestioned benefits of impeachment at trial, ${ }^{250}$ which ensures that the jury will confront an accused who is obliged "to speak truthfully and accurately." 251 On the opposing side of the equation exists "the speculative possibility that impermissible police conduct will be encouraged"252 if the illegal evidence in Harris is not excluded. Framed in this way, the outcome can be no other than the one reached by the Harris Court. The mathematics is simple: faced with purely speculative deterrence on the one hand, and with the well-established objective of finding the truth on the other, to opt for "speculative deterrence" makes no sense at all. Therein lies the beauty of the utilitarian calculus: the equation's balance turns upon the Court's characterization of the deterrence value. The certainties of common sense will always outweigh the less defined notion of what the Court has deemed "speculative deterrence."253

Thus, a troubling question remains: on what basis does one characterize the likely effectiveness of deterrence under any circumstances? Recall that while the Miranda majority flirted with this danger-by counteracting the dissenters' crime-control-based objections with the reputedly empirical claim that police procurement of confessions would

" 250 Id. (one of "the traditional truth-testing devices of the adversary process").

251 Id.

252 Id.

25s See Kamisar, supra note 199, at 621, 648-649 ("[H]ow does one go about deciding whether the exclusionary rule can 'pay its way' in a particular setting without giving free play to one's own views of policy? ... [W] Wen one goes about balancing interests in order to determine whether the exclusionary rule should be applied, it is not only far from clear how the competing interests are to be 'weighed,' but in which scale they should be placed. ... [B]alancing tests 'inevitably become intertwined with the ideological predispositions of those doing the balancing . . .."). 
not be unduly hampered-the Court did not proceed from this premise as its point of departure. In contrast, it is precisely the unsupported, and subsequently refuted, ${ }^{254}$ empirical claim that the Miranda warnings would deter defendants from giving confessions that served as the Miranda dissenters' point of departure. Absent any empirical basis to establish the likelihood or improbability of deterring particular behavior, however, the dissenters' subjective characterization of such deterrence is itself entirely speculative. As a result, to the extent that this claim serves as their point of departure, the legitimacy of the dissenters' judgment remains suspect. Paradoxically, in Harris, the majority inherits the same difficulty by following the Miranda dissenters' lead. Put simply, predicting deterrence is now the majority's point of departure.

In the hands of crime control advocates, however, this problem is transformed into an opportunity. It is precisely the plasticity of the deterrence factor and its susceptibility to manipulation, that supports the advancement of subjectively-posited, judicially-preferred social policy goals. As such, it provides the perfect vehicle for realizing the crime control goal of deterrence through the fast and efficient punishment of the factually guilty. By the same token, it calls to mind Justice Black's outrage at the arbitrariness of judicial subjectivity that was rampant in the era of due process adjudication, when conflicting judicial intuitions of fairness reigned supreme. ${ }^{285}$

Thus, in Harris, the Miranda Court's reading of the fifth amendment privilege is silenced. The recognized need to protect the accused from the naked power of the state-the product of Miranda's interpretive encounter with that constitutional language-yields to a neutralseeming calculus. If new "interpretive" values are at work in Harris, their function remains hidden from view, embedded within, and disguised by, the method the Court deploys to "justify" its preferred outcome. Curiously, the only constitutional "rights" talk the majority in Harris permits itself reflects a different strategy of formal dominance. Rather than conquer a rival discourse from within, ${ }^{256}$ Justice Burger

284 See supra note 175 and accompanying text.

${ }^{265}$ Such judicial subjectivity has been criticized for undercutting stare decisis because it relies on courts' vague, conflicting, and unpredictable intuitions of "fairness." See supra notes $135-38$ and accompanying text.

${ }_{208}$ The Court's use of a seemingly neutral method-namely, balancing competing interests in an effort to maximize "deterrence"-to disguise normative commitments represents a discrete form of dialogic dominance. This strategy of dominance works "within" a competing dialect in the sense that it leaves intact terms that are familiar within that dialect, but translates their meanings (sub voce) to reflect its own dialogic presuppositions. 
taints the very notion of a "right"-and by extension perhaps of a rights-based form of discourse-by association: witness his telling phrase "the right to commit perjury."25z

Recognizing the retrogressive thrust of the Harris majority, the dissenters attempted to restore the interpretive framework that the majority had subverted, struggling to undo its transition into the rhetoric of crime control ideology. In an effort to reorient the majority's analysis, Justice Brennan observed: "The objective of deterring improper police conduct is only part of the larger objective of safeguarding the integrity of our adversary system."258 It is notable here that in conformity with Brennan's recollection of the fifth amendment values that lay at the heart of Miranda's interpretive framework, the "adversary system" in Brennan's vernacular means something quite different from its meaning to the majority. For the Harris dissenters, it stands for a system of criminal justice in which the respect shown by the government "must accord to the dignity and integrity of its citizens."259 This is a far cry from the search for objective truth that informs the majority's understanding of our "adversary process." Indeed, the dissenters' view will grow increasingly marginalized as the crime control ideology gains influence over other ways of thinking and talking about the law of confessions.

In Harris, Chief Justice Burger introduced the essential elements of the utilitarian version of scientific policymaking. In Michigan $v$. Tucker, ${ }^{280}$ decided three years later, Justice Rehnquist did much to fill out the historical and precedential background of the new cost/benefit discourse. However, whether this effort to establish a pedigree for the new law talk will be able to overcome the spectre of illegitimacy that accompanies ideology in the law remains uncertain.

In Tucker, Justice Rehnquist shrewdly exploits the two interlocking aspects of the Miranda decision that are most vulnerable to attack. He criticizes the "hardness" of Miranda's per se rule in an effort to expose its "brittleness." Additionally, he strikes at the strategic compromise by which the Miranda majority itself sought to come to grips with the inflexibility that attends formal rulemaking. To counteract the dissenters" claim that the Court was fashioning a "constitutional straitjacket," the Miranda majority allowed that procedural safeguards other than the one the Court specifically articulated were possible, provided that they met the minimum constitutional standards that the Court's

257 Harris, 401 U.S. at 225.

${ }^{258}$ Id. at 231 (Brennan, J., dissenting).

${ }^{250}$ Id. at 232 (quoting Miranda, 384 U.S. at 460).

280417 U.S. 433 (1974). 
ruling embodied, a condition Rehnquist conveniently omits in Tucker. ${ }^{261}$ In this way, Rehnquist seeks to convert Miranda's "strategic" compromise, as a form of prudent accommodation, into the kind of "fatal" compromise that unravels the unitary interpretive framework that informs and structures the Miranda decision. The effect is potent, but less so perhaps than the perilous consequence of waging a battle by deception.

To be sure, Tucker is a case well chosen for the tactics Rehnquist employs. The case involves a gruesome rape. From the outset, based on ordinary and intuitive common sense, one is powerfully disinclined to set the accused free. The detailed narration of the crime at the beginning of the majority opinion reflects the Court's keen awareness of this sentiment. The evidentiary "illegality" in the case only compounds this "natural" response. Here, as in Harris, the police failed to warn Tucker of one of his Miranda rights. Moreover, the actual legal issue in Tucker is even further removed from Miranda in that it is only indirectly involved in defendant's conviction. The question before the Court in Tucker was whether evidence, obtained from a witness whose identity the police had learned solely from a statement by the defendant, could be used at trial despite the fact that the statement was obtained in violation of Miranda. Given this posture of events, the stage was set to expose the "hardness" of Miranda's per se ruling.

Rehnquist exploits this situation by adopting a proven political stratagem: divide and conquer. The key move comes early in the opinion:

For purposes of analysis in this case we believe that the question thus presented is best examined in two separate parts. We will therefore first consider whether the police conduct complained of directly infringed upon [the defendant's] right against compulsory self-incrimination or whether it instead violated only the prophylactic rules developed to protect that right. We will then consider whether the evidence derived from this interrogation must be excluded. ${ }^{\mathbf{2 6 2}}$

What follows is a sophisticated replay of the Harris cost/benefit calculus. Now, however, it is designed to ensure that the interpretive discourse of Miranda remains only a remote echo wafting through the

${ }^{281}$ Compare Miranda, 384 U.S. at 444 ("unless other fully effective means are devised to inform accused persons of their right to silence . . . the following measures are required") with Tucker, 417 U.S. at 444,446 (finding that the police conduct did not deprive Tucker of his privilege against compulsory self-incrimination by failing to inform him of all of his Miranda rights).

${ }^{262}$ Miranda, 384 U.S. at 439. 
passages of a case cite that has been utterly reconstructed.

Rehnquist's first goal is to redefine the meaning of the fifth amendment privilege against compelled self-incrimination. He starts by stating that " $[t]$ he importance of [the] right does not, by itself, determine its scope, and therefore we must continue to hark back to the historical origins of the privilege, particularly the evils at which it was to strike."263 Rehnquist concludes that these "evils" are present "[w] here there has been genuine compulsion of testimony."264 This conclusion comports with a common sense understanding of "compulsion." However, since this understanding is directly at odds with the counter-intuitive interpretation of the privilege that Miranda proffered, one is entitled to seek persuasive reasons for the Court's shift.

It is the "self-evidence" of Rehnquist's common sense view that must bear the weight of review. However, as we have seen before, a common sense approach cannot sustain such a burden. ${ }^{265}$ While the insertion of a common sense viewpoint in Tucker may deflect the Court from Miranda's counter-intuitive interpretation, common sense remains inadequate as a source of persuasion. Why Rehnquist's particular common sense perspective should prevail, rather than, for example, the McMahon Court's "natural" sensitivity to the plight of the accused, remains unexplained and unjustified in Tucker. This lack of persuasive reasoning is a familiar difficulty associated with common sense decisionmaking.

To be sure, Rehnquist is not unaware of the discrepancy between his common sense view and the interpretation that Miranda presented. For instance, he notes that "the Court in Miranda, for the first time, expressly declared that the Self-Incrimination Clause was applicable to state interrogations at a police station, and that a defendant's statements might be excluded at trial despite their voluntary character under traditional principles." 266 Rather than argue the merits of his own viewpoint, however, Rehnquist simply negates Miranda's interpretation by radically disengaging it from the constitutional text that it construes.

By this move, Rehnquist converts Miranda's strategic compromise into one of compromised self-dissolution. Concentrating upon the $\mathrm{Mi}$ randa majority's attempt to repel the spectre of inflexible formalism (i.e., its expressed openness to methods of protecting the accused's fifth

${ }^{283}$ Id. at $439-40$.

${ }^{264}$ Id. at 440 . Justice Rehnquist subtly reunites the post-Brown (constitutionalized) voluntariness standard with the pre-Brown (evidentiary) trustworthiness standard. Id. at 448 n.23.

${ }^{205}$ See supra notes 79-87 and accompanying text.

${ }^{268}$ Tucker, 417 U.S. at 443. 
amendment rights other than the specific method it promulgates), Rehnquist wrote: "The Court recognized that these procedural safeguards were not themselves rights protected by the Constitution but were instead measures to insure that the right against compulsory selfincrimination was protected."267

If this statement has any meaning at all, beyond stating the truism that since the Miranda safeguards are safeguards, they cannot be rights, it is undoubtedly not the way that the Miranda Court understood the requisite warnings it had authored. ${ }^{288}$ By virtue of this disingenuous construction, Tucker manages to collapse the unified interpretive framework of Miranda - the very basis on which the scattered intuitions of due process discourse were made stable and predictable-into a mere "practical" guide for police conduct. Rehnquist, ever sensitive to the persuasive power of a phrase, elects to call them "prophylactic rules. ${ }^{\text {'269 }}$

Having discounted the constitutional basis of Miranda's interpretation of the fifth amendment privilege, Rehnquist is now free to return to his own historical analysis, and to what the privilege really means, namely the protection against "genuine compulsion."270 Thus, Rehnquist's history shows that the simple fact of custodial interrogation, which Miranda had construed as sufficiently compelling to trigger the protective principles embodied by the fifth amendment privilege, ${ }^{271}$ is now deemed to fall short of the Court's understanding of "compulsion." As Rehnquist puts it, "[c]ertainly no one could contend that the interrogation faced by [Tucker] bore any resemblance to the historical practices at which the right against compulsory self-incrimination was aimed."272 The weight of Rehnquist's common sense view rests upon this unexplained and unjustified "certainty," but, with this certainty intact, Rehnquist has effectively disemboweled Miranda.

Had Rehnquist meant to return the Court to the pre-Brown (preconstitutionalized) era of confessions law, his common sense understanding of "compulsion" would have been well suited to that end. Tucker did not, however, denude Miranda of all significant content in order simply to restore the freewheeling days of ordinary and intuitive

${ }^{267} I d$. at 444.

${ }^{268}$ See supra note 197.

289 Tucker, 417 U.S. at 439.

${ }^{270}$ See id. at $439-41$.

${ }^{271}$ Miranda, 384 U.S. at 467 ("We have concluded that without proper safeguards the process of in-custody interrogation of persons suspected or accused of crime contains inherently compelling pressures which work to undermine the individual's will to resist and to compel him to speak where he would not otherwise do so freely.").

${ }^{272}$ Tucker, 417 U.S. at 444. 
common sense. Common sense was but an instrument of Miranda's demise, not its replacement. Miranda's replacement is found in the axiomatic presuppositions that guide and inform the Court's utilitarian, cost/benefit advocacy of crime control policymaking.

The court in Tucker, borrowing, as it had in Harris, from fourth amendment jurisprudence, ${ }^{273}$ clearly stakes out its new position. Deterrence is now explicitly identified as the principal standard to be used in determining whether or not to exclude evidence from trial. ${ }^{274}$ Moreover, having set the terms of the equation in this way, as in Harris, the Tucker Court arrives at the only "sensible" conclusion. Apparently, for again the Court is not explicit here, the deterrent effect upon future police conduct to be gained by excluding the particular evidence at issue in Tucker is insufficient to warrant its exclusion. ${ }^{275}$ Not surprisingly, the crucial factor, the efficacy of deterrence in the particular case, remains shrouded in mystery. How does the Court know the nature of the deterrent effect of exclusion? Perhaps it does not really matter. In practice, the deterrence factor operates like a wild card, permitting the Court to champion whenever it deems proper the fast and efficient punishment of the factually guilty.

Thus, when the Court inserts ordinary common sense values into its exclusionary calculus, ${ }^{276}$ the Court pits " 'society's interest in the effective prosecution of criminals " $"$ 277 against an apparently speculative deterrent force. Yet it is not unreflective and unsystematic common sense that triumphs. Rather, the triumph goes to an entirely different discourse: namely, the reflective and systematic dialect of SP, and more specifically, to the utilitarian form of that dialect, manifest in this area of the law as the ideology of crime control.

To find that the crime control ideology confirms in the end what it

${ }^{273}$ See id. at 446-47 (citing United States v. Calandra, 414 U.S. 338, 347 (1974)); Harris, 401 U.S. at 224-25 (citing Walder v. United States, 347 U.S. 62 , 65 (1954)).

274 Tucker, 417 U.S. at 446-47.

278 Id. at 448.

${ }^{276}$ Tucker identifies one important consideration in this calculus as "the strong interest under any system of justice of making available to the trier of fact all concededly relevant and trustworthy evidence." Id. at 450 .

${ }^{277}$ Id. (quoting Jenkins v. Delaware, 395 U.S. 213, 221 (1961)). The Tucker Court's use of the phrase "prosecution of criminals" (emphasis added) is instructive. When viewed from a non-crime-control perspective, one might describe the target of state prosecution as those who are accused of crime. The difference in the two descriptions seems to rest upon the presumption of innocence. For a contemporary articulation of crime control ideology, see N.Y. Times, Oct. 12, 1986, § 6 (Magazine), at 92 (referring to Miranda and Mapp v. Ohio, 367 U.S. 643 (1961)), Attorney General Meese stated that these rulings have "inhibited truth in the courtroom ... and cast aside probative evidence for non-truth-finding reasons. Neither Mapp nor Miranda helps any innocent person. They only help guilty people."). 
affirms at the outset should not be surprising. After all, what else can one expect from a form of law talk that takes as its point of departure "self-evident" axioms, such as "deterrence," and then proceeds systematically to narrate facts and assess meanings in ways that those axioms dictate. It is this feature of conceptual and narrative closure (i.e., evading the controversy that surrounds competing readings of an applicable text), that is at work when judicial presuppositions operate from the SP system in question, rather than speak about it.

In Tucker, Justice Douglas alone seemed to recognize and understand the danger embodied in the majority opinion. Responding to Rehnquist's deconstitutionalization of Miranda, Douglas made clear in his dissenting opinion that "[ $t$ ]he Court is not free to prescribe preferred modes of interrogation absent a constitutional basis. We held the 'requirement of warnings and waiver of rights [to be] fundamental with respect to the Fifth Amendment privilege,' and without so holding we would have been powerless to reverse Miranda's conviction."278 Then, restoring Rehnquist's vital omission from the text of the Miranda majority's "strategic" compromise, Douglas went on to observe: "While Miranda recognized that police need not mouth the precise words contained in the Court's opinion, such warnings were held necessary ' $u n$ less other fully effective means are adopted to notify the person' of his rights."279 In concluding, Douglas returned to the spirit and authority of Miranda:

Miranda's purpose was not promulgation of judicially preferred standards for police interrogation, a function we are quite powerless to perform; the decision enunciated "constitutional standards for protection of the privilege" against self-incrimination. People who are in jail because of a State's use of unconstitutionally derived evidence are entitled to a new trial, . . . without regard to when the constitutional violation occurred, when the trial occurred, or when the conviction became "final."

Eight years after Miranda, only one Justice is heard to champion the critique (eloquently advanced in previous years by Justice Black ${ }^{281}$ ) of

278 Tucker, 417 U.S. at 462-63 (Douglas, J., dissenting) (quoting Miranda, 384 U.S. at 476 ).

${ }^{279}$ Id. at 463 (Douglas, J., dissenting) (emphasis added) (quoting Miranda, 384 U.S. at 479$)$.

${ }^{280}$ Id. at 465-66 (Douglas, J., dissenting).

281 See, e.g., Adamson v. California, 332 U.S. 46, 89 (1947) (Black, J., dissenting) ("I fear to see the consequences of the Court's practice of substituting its own concept of decency and fundamental justice for the language of the Bill of Rights as its point of 
the Court's return to subjective instrumentalism. Only Douglas seemed to recognize the incongruity of "balancing" the state's claimed "vested interests" against " "the right of persons adjudged guilty of crime to challenge their unconstitutional convictions at any time'."282

In any event, the question remains: if Miranda lacks constitutional authority to outweigh the state's interest in all cases, as Tucker proclaims, on what basis can it intervene in a state court conviction? Yet, by the same token, if Tucker proceeds from a subjectively preferred social policy, on what basis can it claim constitutional authority? Where is "deterrence" in the service of crime control ideology, inscribed in the Constitution?

As the new cost/benefit talk gained ground in the law of confessions, the concern expressed by Justices Douglas and Black would spread. New York v. Quarles, ${ }^{283}$ decided ten years after Tucker, is a case in point. There, the Court created a "public safety" exception that "outweighs the need for a prophylactic rule protecting the Fifth Amendment privilege against self-incrimination." ${ }^{284}$ In this case, the police were told by a woman who approached their patrol car that an armed, black male, wearing a black jacket with the words "Big Ben" printed on it, had just raped her. She said he had just gone into a nearby supermarket. Following the woman's directions, one officer entered the store, while the other radioed for assistance, and observed Quarles, whom he believed to be the suspect she had described. The officer apprehended Quarles, frisked him, and discovered an empty shoulder holster. The suspect was then handcuffed. Following this, the officer asked Quarles where the gun was. Quarles said, "the gun is over there," nodding in the direction of some empty cartons. The gun was subsequently retrieved, and Quarles was charged with criminal possession of a weapon. ${ }^{285}$

It was not contested that the defendant was effectively in police custody by the time he was handcuffed. ${ }^{286}$ According to Miranda, then, before any of his responses to police inquiries could be used against him, he was to be informed of his rights. ${ }^{287}$ These warnings, however, were not given to Quarles until after his arrest. ${ }^{288}$ Therefore, on a

departure in interpreting and enforcing that Bill of Rights.").

282 Tucker, 417 U.S. at 467 (quoting Linkletter v. Walker, 381 U.S. 618, 653

(1965) (Black, J., dissenting)).

283467 U.S. 649 (1984).

284 Id. at 657.

${ }^{285}$ Id. at 651-52.

288 Id. at 653 .

${ }^{287}$ Miranda, 384 U.S. at 479.

${ }^{288}$ Quarles, 467 U.S. at 652. 
straightforward reading of Miranda, his statement, and the gun that was retrieved as a result of that statement, must be excluded. The Supreme Court found otherwise. ${ }^{289}$

The Quarles Court ruled that the missing gun posed a threat to public safety that outweighed the need for Miranda's "prophylactic rule."290 Indeed, the majority in Quarles went a step further by inviting the police officers to engage in, and thus be guided by, the same cost/benefit discourse used by the Court. In situations involving the public safety, the Court said, officers are called on to "balance the social and individual interests involved in the specific circumstances they confront'."291 The officer's alleged perception of danger, therefore, has now become sufficient to suspend Miranda's protection. That perception, if Quarles is any guide, would seem to allow a long tether. After all, in Quarles the Court found a sufficient risk to public safety to overcome Miranda's requirements despite the fact that at the time Quarles was questioned he was the only suspect and was unarmed and handcuffed. ${ }^{292}$ The only persons who could have been endangered-certainly not the police, who by this time had reholstered their revolvers and who conceded at trial that they felt no threat from Quarles ${ }^{293}$ - were customers or employees of the store. According to the record, however, Quarles was apprehended at midnight, and the store was deserted except for clerks at the checkout counter. ${ }^{284}$

The lesson, therefore, is clear: the narrative impulse that informs and shapes the Court's story comports with the majority's underlying ideological and dialogic presuppositions. While it seems reasonable to expect that police commitment to the ideology of crime control is unlikely to be less than the Court's own, the majority in Quarles takes no chances. In order to ensure that the meaning of this parity of interests is fully appreciated, the Court provides police with explicit guidance as to how they are to think and talk about the circumstances they confront in their effort to control crime. ${ }^{295}$

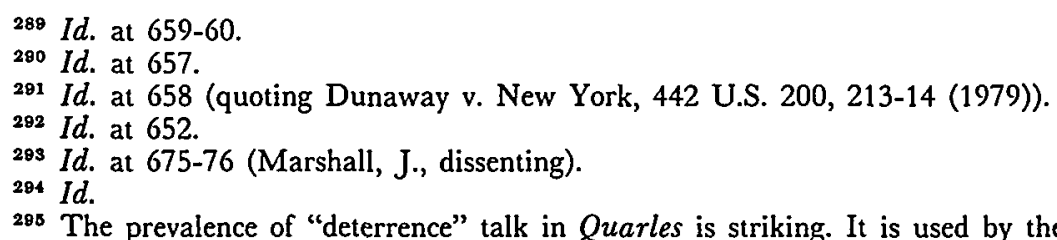
majority not only to describe and assess the impact upon police of excluding Quarles' statement, but also to describe the effect of giving Miranda warnings to persons accused of crime. The Court notes: "had Miranda warnings deterred Quarles from responding [to the officer's question] about the whereabouts of the gun," the officers could not have "insure[d]" that "further danger to the public" would not occur. Id. at 657.

Notwithstanding the disingenuousness of the Court's concern, this statement also 
In the aftermath of Quarles, it remains unclear exactly what kinds of situations may involve "public safety." What is clear, however, is that the deconstitutionalization of Miranda has now opened the way to further police empowerment, the very danger Miranda had sought to repel. ${ }^{298}$ By the same token, the time-consuming and unpredictable case-by-case analysis that due process talk had engendered, ${ }^{297}$ and that Miranda's per se rule had been specifically designed to overcome, ${ }^{298}$ is now restored. How else can a court assess whether Miranda's requirements were in fact "outweighed" by a threat to public safety except by examining for itself the particular "endangering" circumstances?

Quarles evinces the ascendancy of crime control ideology. As their dissenting opinion in Quarles shows, Justices Marshall, Brennan, and Stevens had by now clearly caught on:

The majority implies that Miranda consisted of no more than a judicial balancing act in which the benefits of "enlarged protection for the Fifth Amendment privilege" were weighed against "the cost to society in terms of fewer convictions of [factually] guilty suspects." . . . The majority now proposes to return to the scales of social utility to calculate whether Miranda's prophylactic rule remains cost-effective when threats to the public's safety are added to the balance. ... Whether society would be better off if the police warned suspects of their rights before beginning an interrogation or whether the advantages of giving such warnings would outweigh their costs did not inform the Miranda decision. On the contrary, the Miranda Court was concerned with the proscriptions of the Fifth Amendment, and, in particular, whether the Self-Incrimination Clause permits the government to prosecute individuals based on statements

captures the plasticity of the deterrence concept. The Court is unwilling to speculate about the efficacy of evidentiary exclusion in deterring unlawful police behavior, yet it does not hesitate to assess the effect of deterrence upon the behavior of the accused. The very creation of the Quarles public safety exception presupposes that the accused would be deterred from speaking if given the Miranda warnings.

Thus, we see that the efficacy of deterrence is closely tied to the value or policy being advanced. In Quarles, crime control, not the dignity and autonomy values that inform Miranda, guide the Court's understanding of what constitutes effective deterrence.

${ }^{288}$ Miranda, 384 U.S. at 447 ("Unless a proper limitation upon custodial interrogation is achieved ... there can be no assurances that practices of this [unacceptable] nature will be eradicated in the foreseeable future.").

297 See Ogletree, supra note 106, at 1833-34 (discussing the inadequacies of the case-by-case approach).

${ }^{298}$ Id. at 1837 (noting that the Court established concrete constitutional guidelines after rejecting the case-by-case approach). 
made in the course of custodial interrogations. ${ }^{299}$

Nor were the larger implications of SP-utility talk lost on the dissenters:

The majority should not be permitted to elude the Fifth Amendment's absolute prohibition simply by calculating special costs that arise when the public's safety is at issue. Indeed, were constitutional adjudication always conducted in such an ad hoc manner, the Bill of Rights would be a most unreliable protector of individual liberties." ${ }^{\text {300 }}$

Despite this increased recognition, the ascendancy of SP-utility remained unchecked and undaunted. Even when Justice O'Connor took issue in Quarles, identifying the "rigidity" of Miranda's rule as a source of its "strength," 301 the new cost/benefit talk remained in place. Indeed, in a subsequent decision one year after Quarles, Justice O'Connor reaffirmed Tucker's retrogressive step to the case-by-case, fact-bound analysis of due process ("voluntariness") talk. In Oregon $v$. Elstad, ${ }^{302}$ we also witness in graphic form the way in which conflicting "self-evident" truths, attributed by advocates of opposing views of common sense, make sense in contexts provided not by common sense at all, but rather by other competing dialects. Here, we reach the paradoxical return that will cap our dialogic study of confessions law.

The specific question before the Elstad Court was whether the defendant's confession, made in police custody without the benefit of Miranda warnings, tainted a second confession made shortly after the first one, but after full Miranda warnings had been given to and waived by the defendant.

For Justice O'Connor, an initial, constitutionally invalid admission of guilt made "involuntarily" under the influence of police coercion "undermine[s] the suspect's will to invoke his rights once they are 57).

${ }^{299}$ Quarles, 467 U.S. at 681-82 (Marshall, J., dissenting) (quoting id. at 656-

${ }^{300}$ Id. at 688 (Marshall, J., dissenting).

so1 Id. at 664 (O'Connor, J., concurring in part and dissenting in part) (quoting Fare v. Michael C., 439 U.S. 1310, 1314 (1978)).

302470 U.S. 298 (1985). Justice O'Connor has even more recently signaled the Court's readiness to re-embrace the due process standard. See Miller v. Fenton, $106 \mathrm{~S}$. Ct. 445, 449 (1985) ("Indeed, even after holding that the Fifth Amendment privilege against compulsory self-incrimination applies in the context of custodial interrogations ... the Court has continued to measure confessions against the requirements of Due Process." (citations omitted)). But cf. Moran v. Burbine, 106 S. Ct. 1135, 1143 (1986) (reaffirming that Miranda "strikes the proper balance between society's legitimate law enforcement interests and the protection of the defendant's Fifth Amendment rights"). 
read to him," thus tainting a second, constitutionally valid admission. ${ }^{303}$ However, she concludes that an initial, "voluntary" admission like the one at issue in Elstad does not taint an admission made after administration of Miranda warnings. ${ }^{304}$ The criteria by which O'Connor measures admissibility in these situations are provided by "the Fifth Amendment goal of assuring trustworthy evidence" and the "general goal of deterring improper police conduct." an OCS evidentiary sense of the constitutional text in question; the latter goal articulates the preferred goal of crime control ideology. ${ }^{306}$ Taken together, these two guiding factors assume away Miranda's original interpretive framework.

In Elstad, the Court was convinced that the confession was trustworthy. For the Court, the absence of coercion or improper tactics allowed the suspect to freely choose whether or not to give a statement. Since defendant's initial unwarned admission was "voluntary," it violated only the Miranda rule. As the Court stated, "[A] subsequent administration of Miranda warnings . . . ordinarily should suffice to remove the conditions that precluded the earlier admission. In such circumstances, the finder of fact could reasonably conclude that the suspect made a rational and intelligent choice whether to waive or invoke his rights." ${ }^{307}$ Underlying this conclusion is Justice O'Connor's assertion that "the causal connection between any psychological disadvantage created by his admission and his ultimate decision to cooperate is speculative and attenuated at best."308 Moreover, the majority's second criterion for admission is also satisfied, since there is no deterrent benefit to be gained from excluding the second admission. ${ }^{309}$

The dissenters, on the other hand, view the majority's conclusions as making no sense at all. This is not surprising, given their sharply divergent points of departure. According to Justice Brennan, the failure to provide Miranda warnings to defendants in police custody leaves

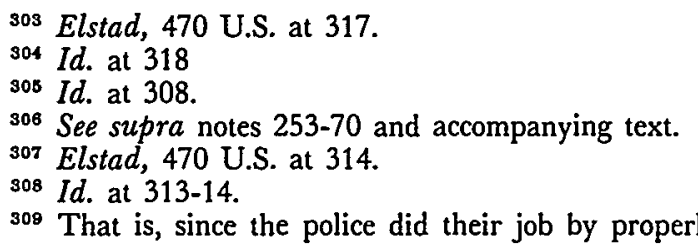

Miranda ho is, since the police did their job by properly warning defendant of his nating statement "serves no purpose." Id. at 318. What "improper police conduct" would such exclusion "deter"? Of course, had the Court focused upon the initial police impropriety as the real basis for constitutional objection, as well as for the second statement's existence, the "deterrence" question might not have been so easily resolved. See id. at 309 (noting that Miranda only applies when there is "actual coercion," or when other circumstances exist that are "calculated to undermine the suspect's ability to exercise his free will"). 
uncured the presumption of coercion that accompanies any custodial interrogation. Since the situation in Elstad merely describes one method of using an initial admission as leverage to get a subsequent admission after the warnings are given, Justice Brennan finds a "taint" of coercion left hanging over the defendant's first self-incriminating admission. ${ }^{310}$ In the dissenters' view, then, contrary to the majority's analysis, there is good reason not to trust the second admission. Indeed, Brennan points out that the "overwhelming majority of state courts that have considered the issue" share this "common sense" mistrust of second admissions. ${ }^{311}$

Based on this common sense understanding of individual behavior, it is not the lack of overt police coercion that is of concern. Rather, it is the "practical" (i.e., OCS) observation that, "[A]fter an accused has once let the cat out of the bag by confessing, no matter what the inducement, he is never thereafter free of the psychological and practical disadvantages of having confessed'."312 For their part, the majority casts this common sense "truth" as "speculative." To the dissenters, however, the majority's characterization seems but an act of "marble-palace psychoanalysis." 313 In other words, what appears to the majority as a "speculative" theory of human behavior appears to the dissenters as plain common sense. Conversely, the "fact" that an initial uncoerced statement cannot "taint" a later, freely made one appears to the dissenters as "pseudo-scientific" analysis, but is to the majority a plainly empirical observation.

The situation is paradoxical. For the majority, the Miranda warnings may not be of a constitutional dimension, but they work; they may not be mandated by the fifth amendment privilege, but they do effectively ensure that defendants' confessions will be knowingly and voluntarily made. ${ }^{314}$ In contrast, for the dissenters the Miranda warnings are constitutionally mandated, but they are not as effective as the majority professes to believe since they cannot remedy Miranda violations.

How is one to make sense of this paradox? What can it mean when the majority in Elstad pays lip service to common sense trustworthiness and the intuitive "voluntariness" standard of due process, while at the same time its analysis of individual behavior relies upon a "legalistic" device, namely the Miranda warnings? After all, it is precisely

s10 Id. at 331 (Brennan, J., dissenting).

311 Id. at 322-24.

\$12 Id. at 325 (quoting United States v. Bayer, 331 U.S. 532, 540 (1947)).

s13 Id. at 324.

314 See id. at 305 (quoting Quarles, 467 U.S. at 654). 
the Court's common sense and voluntariness talk that has systematically subverted the rights-protecting aspect of the warnings, thus reducing Miranda itself to what has been characterized as an "illegitimate exercise of raw judicial power."315 Conversely, how are we to understand the Elstad dissenters' emphasis upon the counter-intuitive, constitutional dimension of the Miranda warnings, on the one hand, while their understanding of individual behavior remains committed to the perspective of common sense, on the other-the very view that led the dissenters in Miranda to question the efficacy of such warnings in the first place?

One can find an answer to these paradoxical musings by deciphering the dialogic perspective that serves as the decisionmakers' point of departure. In McMahon, for example, the New York Court of Appeals' point of departure was the ordinary common sense perspective of "factual" guilt and "manifest criminality"316; in Brown, it was the "self-evident" intuition of due process fairness ${ }^{317}$; in Miranda, it was the counter-intuitive interpretative framework of Prudent Interpretation $^{318}$; and in Tucker, it was the systematic deployment of the deterrence-oriented, crime control ideology of Scientific Policymaking (in its utilitarian variant). ${ }^{319}$ The forms of discourse that are at work in a particular opinion should be assessed in the light of that opinion's dominant dialect. Whether common sense, for example, is being used as a strategy of formal dominance for the advancement, say, of crime control ideology or individual rights talk or whether it is being offered in its own right, as "evidence" of some incontrovertible "truth," tells us much about the meaning and goal of the particular decision in question. This initial dialogic analysis, by which the (witting or unwitting) dialogic commitments of particular decisionmakers are decoded, permits a formal assessment of decisional legitimacy. The latter assessment proceeds on the basis of those criteria, described in Part III, which the dialects of criminal procedure themselves provide. These criteria coincide with the virtues and defects that each criminal procedure dialect uniquely enjoys.

According to this analysis, then, factual narratives and legal meanings - the way a particular decisionmaker understands self, others, and social institutions- "make sense" (or fail to) in the context of specific dialogic presuppositions. It is in this sense that the paradoxes of Elstad,

s15 Id. at 371 (Stevens, J., dissenting).

s16 See supra notes 68-80 and accompanying text.

317 See supra notes 98-107 and accompanying text.

318 See supra notes $172-215$ and accompanying text.

s18 See supra notes 273-82 and accompanying text. 
and of other cases in which particular dialogic commitments and strategies of formal dominance are at work, may be understood and assessed. Thus, for example, the "speculative" nature of the "taint" of Elstad's first (unwarned) admission upon his second is "self-evident" to the majority. First, the Elstad Court's dialogic premise assumes away "coercion" by deconstitutionalizing Miranda. Second, its view of human nature, consistent with its utilitarian presuppositions, presumes that individual free will is generated as a calculus of pleasures and pains. Linking these two premises together, the Court "naturally" concluded that, absent some concrete evidence that the defendant's "free will" was "tainted," there is no reason to presume that his choice to speak was anything but that good which he desired. ${ }^{\mathbf{3 2 0}}$

The Elstad dissenters, in contrast, retain Miranda's constitutional framework and its presumption of "coercion." In the service of this perspective, common sense "dictates" that "[h]aving once confessed [the accused] was ready to confess some more." "321 Thus the battle between the dissenters and the majority over the meaning of defendant's "free will" remains ineluctably tied to the prior presuppositions that are built into their respective dialogic commitments. Moreover, it is no coincidence that while the dissenters' view would enhance constitutional safeguards that protect the autonomy and dignity of the accused, even at the expense of crime control objectives, the majority achieves precisely the opposite result. While paying lip service to Miranda's protection against "official lawlessness," 322 the Elstad majority nevertheless provides police with strong incentives to exploit unlawful interrogation tactics at the expense of the accused. ${ }^{323}$

This enhancement of official power has the ancillary effect of bolstering defendant's incentive to plead guilty, to admit factual guilt and forego various legal defenses that might be available, in order to strike a bargain with the state. That is, the more evidence the state has to strengthen its case against the accused, the greater is the latter's incentive to bypass the unpredictable, and most likely harsher, punishment that will result from going to trial. This fact is not hidden from the accused. ${ }^{324}$ In the process of churning out "efficient" convictions, how-

s20 See Elstad, 470 U.S. at 314.

s21 Id. at 331 (Brennan, J., dissenting) (quoting State v. Lekas, 201 Kan. 579, 587-88, 442 P.2d 11, 19 (1968)).

322 Id. at 318 ("[T]he finder of fact must examine the surrounding circumstances and the entire course of police conduct with respect to the suspect in evaluating the voluntariness of his statements.").

${ }^{323}$ See id. at 342-44 (Brennan, J., dissenting).

s24 See, e.g., Justice Harold Rothwax's colloquy: Justice Rothwax who, facing a case involving two repeat felons charged with burglary, appointed counsel from among 
ever, plea bargaining "de-culturizes" the criminal process by straining out inherited texts, such as cases, statutes, and constitutions, some of which might well contain a legitimate basis for pleading the defendant innocent. ${ }^{325}$ Concomitantly, plea bargaining vitiates the interpretive dimension of the decisionmaking process, which is another token of crime control's dialogic dominance. ${ }^{326}$

Elstad's likely enhancement of plea bargaining also shows up the Court's beguiling deployment of common sense discourse. Rather than inviting the participation of the lay public, the principal dialogic community of OCS, as juror and citizen spectator, the plea bargaining process excludes them. Plea bargaining privatizes the criminal process by converting it into a discourse among experts: those legal representatives of the parties involved who bargain over the confessed crime's worth. Thus, the utilitarian strain of SP manifests its ascendancy over yet another dialogic community, for in addition to the lay public, it also excludes the expert interpreter of inherited texts. Indeed, even the public's representatives are excluded from the plea bargaining process, as legislated sentencing goals bow to the bargaining tactics of counsel. The ensuing gain goes to the state. As plea bargaining deregulates and enhances prosecutorial power, it increases the state's power to impose terms that will induce defendant's settlement. ${ }^{327}$

those waiting in the courtroom's front row for one of the defendants, heard the District Attorney's offer of two to four years, then stated to defendants' counsel, "After today, it's 3 to 6 , after that, it's 4 to 8 . . . . If they're ever going to plead, today is the time to do it." After defendants' rejection of the offer, Rothwax declared: "We'll make it very easy. It's 4 to 8 after today. Let's play hardball." For One Zealous Judge, Hard Bargaining Pushes Cases Through the Courts, N.Y. Times, Apr. 29, 1985, at B1, col. 1, B4, col. 3 .

325 Cf. Rhodes, Plea Bargaining: Its Effect on Sentencing and Convictions in the District of Columbia, 70 J. CRIM. L. \& CRIMInology 360, 370 (1979) (based upon a model of cases that went to trial, the likelihood of acquittal for defendants who pled guilty in the District of Columbia was approximately $34 \%$ for assault cases, $16 \%$ for robbery cases, and $31 \%$ for burglary cases).

${ }^{328}$ See Schrock \& Welsh, Reconsidering the Constitutional Common Law, 91 HARV. L. REv. 1117, 1171 (1978) ("TT] he moral force behind a rule is far less when the rule is justified by mere utility than when the rule is declared to be a necessary part of our fundamental liberties.").

${ }^{327}$ See, e.g., Arenella, Rethinking the Functions of Criminal Procedure: The Warren and Burger Courts' Competing Ideologies, 72 GEo. L.J. 185, 216-19 (1983) (arguing that while plea bargaining may serve efficiency and deterrence goals, it undermines the moral component of the criminal law, and hence the criminal justice system itself, by blocking out public involvement and frustrating legislatively imposed guidelines in favor of private negotiation in which the parties make the moral judgment); Halberstam, Towards Neutral Principles in the Administration of Criminal Justice: $A$ Critique of Supreme Court Decisions Sanctioning the Plea Bargaining Process, $73 \mathrm{~J}$. CRIM. L. \& CRIMINology 1, 8-15 (1982) (discussing Supreme Court decisions that uphold the state's ability to impose harsher sentences on defendants who exercise their right to trial instead of plea bargaining). 
Thus, the deconstitutionalization of state confessions law, and the concomitant ascendancy of crime control ideology, converge upon plea bargaining as the most cost effective vehicle for deterrence. The result is an expanded outlet in which market forces operate, notwithstanding market failure factors that SP-utility talk is ill-suited to note, much less cure $^{328}$ In any event, as the legal experts pursue cost/benefit analysis in their bargaining over defendant's fate, the totalization and dominance of this exclusive form of law talk increases.

This development in the law of confessions, the process by which Miranda's interpretive framework is uprooted from the case law and displaced by SP-utility's cost/benefit talk, also dovetails with the Supreme Court's current understanding of the new federalism. Absent any apparent need for constitutional interpretation, the federal courts may now remove themselves from active participation in the resolution of state conflicts in this area of the law. The increase in state court responsibilities that this development augurs is well illustrated by recent trends in the law on post-arrest silence. ${ }^{329}$ This area reveals the increasing tendency of the Court to return not only to the pre-Miranda days of ad hoc, case-by-case decisionmaking, but even further back to the days before Brown, when the evidentiary, (OCS) standard of trustworthiness predominated.

${ }^{\text {s28 }}$ See, e.g., In re Gault, 387 U.S. 1, 44-45 (1967) ("IU]nder certain stresses a person . . . may falsely acknowledge guilt. This possibility arises wherever the innocent person is placed in such a situation that the untrue acknowledgement of guilt is at the time the more promising of two alternatives between which he is obliged to choose; that is, he chooses any risk that may be in falsely acknowledging guilt, in preference to some worse alternative associated with silence." (quoting $3 \mathrm{~J}$. WIGMORE, supra note 63, $\S 822)$ ); S. Skadish \& M. Paulsen, Criminal. Iaw and Its Processes 758 (3d ed. 1975) ("Plea bargaining is not only an invisible procedure but, in some jurisdictions, a theoretically unsanctioned one. In order to satisfy the court record, a defendant, his attorney, and the prosecutor will at the time of sentencing often ritually state to a judge that no bargain has been made." (quoting THE PRESIDENT'S COMM'N ON LAW Enforcement \& The Admin. of Justice, The Ghallenge of Crime in a Free Soc'y 78 (1967))); see also Arenella, supra note 327, at 218 \& n.192 (although the "market-system justification for plea bargaining ignores the criminal law's moral content and oversimplifies its punishment goals .. . looking at criminal procedure as a market system is useful to the extent that it highlights major structural defects in the market that may prevent it from functioning in a manner that maximizes deterrence with minimum allocative inefficiencies"); Berger, The Supreme Court and Defense Counsel: Old Roads, New Paths-A Dead End?, 86 Colum. L. Rev. 9, 64 (1986) ("Every practitioner knows, for one thing, how often the sins of counsel are buried in guilty pleas, which yield no transcript except for the defendant's bare allocution and, therefore, no intrinsic proof of inept technique or unpreparedness." (footnote omitted)).

${ }^{329}$ See, e.g., Note, Impeachment with Post-Arrest Silence: The Emergence of a "New Federalism" Approach, 19 AM. Crim. L. REv. 751, 765 nn.119-22 (1982) (citing numerous instances of state courts' application of heightened state constitutional protection to such areas as search and seizure, admissibility of statements, right to counsel, and cruel and unusual punishment). 
This retrogression comes in several steps. First, the lesson of Harris and Tucker was assimilated. Defendant's postarrest silence could now be assessed not in the constitutional rights framework provided by Miranda, but rather in the discourse of prior periods: namely, the intuitive due process fairness talk spawned initially by Brown and the Courts' earlier common sense reliance upon trustworthiness. Both of these earlier dialects are deployed in Doyle v. Ohio. ${ }^{330}$ In that case, after having been advised of their Miranda rights, the defendants opted not to make any statements to police. The prosecution later used this silence against the defendants as a means of impeachment at trial. The Supreme Court concluded that this was impermissible for two reasons. First, in the wake of Miranda warnings, "every post-arrest silence is insolubly ambiguous."331 Evidently relying upon ordinary common sense, as had Justice Marshall in Hale, the Doyle Court concluded that such evidence cannot be trusted.

Here, however, the inherently conflicting nature of ordinary common sense judgments reappears. As Burger argued in his concurring opinion in Hale, "there is not a scintilla of empirical data" to support this restrictive view toward post-arrest silence since there is no view that is "generally accepted as validated by ordinary human experience." 332 In Doyle, Justice Stevens's dissent, joined by Justices Rehnquist and Blackmun, offers a similar complaint. ${ }^{333}$ The authority for the dissenters' alternative ordinary common sense observations, however, is equally problematic. Thus, once again, we see the recapitulation of the type of controversy OCS spawned in the early case law, such as the conflict between McMahon and Teachout over disparate assumptions about human nature.

The Doyle majority sidesteps the Hale controversy by noting, as it must, that since this case involves a state law conflict, its federal supervisory powers are not applicable, as was the case in Hale. ${ }^{334}$ Thus, switching from ordinary to rational common sense talk, (i.e., from eve-

s30 426 U.S. 610 (1976).

ss1 Id. al 617.

${ }^{332}$ Hale, 422 U.S. at 181 (Burger, C.J., concurring).

${ }^{393}$ Doyle, 426 U.S. at 621-22 (Stevens, J., dissenting) ("In my judgment there is nothing deceptive or prejudicial to the defendant in the Miranda warning. Nor do I believe that the fact that such advice was given to the defendant lessens the probative value of his silence, or makes the prosecutor's cross-examination about his silence any more unfair than if he had received no such warning. . . . [The defendant's] silence is tantamount to a prior inconsistent statement and admissible for purposes of impeachment." (footnotes omitted)).

${ }^{334}$ See id. at 617 n.8; see also Hale, 422 U.S. at 181 (The Court concluded, in its exercise of supervisory power over lower federal courts, that the defendant was entitled to a new trial.). 
ryday expectations about how guilty people behave to pseudo-interpretive intuitions of fairness) the majority proffers a second reason for its ruling: "[I]t would be fundamentally unfair and a deprivation of due process to allow the arrested person's silence to be used to impeach an explanation subsequently offered at trial." 335 This return to due process (fundamental fairness) talk was soon followed by a further step, which advanced the Court's twin goals of crime control ideology and the new federalism.

In Fletcher $v$. Weir, ${ }^{396}$ the Court ruled that defendant's postarrest silence was admissible at trial for impeachment purposes because there was no evidence on the record that Miranda warnings had been given. ${ }^{337}$ Fletcher exhibits a tactic similar to the one adopted by the majority in Elstad. In both cases the Court assumes away any constitutional basis for the decision so that it can advance instead separate, subjectively preferred policy goals. In Elstad, once Miranda's presumption of coercion lacked constitutional dimension, an unwarned, but uncoerced, admission could retain its evidentiary usefulness. Similarly, in Fletcher, the Court released Doyle's moorings to the Federal Constitution so that Doyle could operate thereafter in a constitutional vacuum, like Miranda. ${ }^{\mathbf{3 3 8}}$ As to whether or not the warnings should have been given, the Fletcher Court has nothing to say. In the "presumed" absence of Miranda warnings, for the record is unclear, Doyle's due process concerns become extraneous. According to this type of reasoning, then, police are worse off if they follow the Miranda rule than if they do not. If they advise an accused of her Miranda rights, they cannot use her ensuing silence as evidence against her at trial. If no warnings are given, however, then no bar exists. This leaves the police with a clear incentive to withhold warnings. The Court is also willing to shift to the defendant the burden of proving that the requisite warnings had been given, a burden Miranda initially had placed upon the state. ${ }^{339}$ Thus, the failure to provide Miranda warnings not only ceases to violate the fifth amendment privilege, but it also comports with the Court's current intuitive sense of what due process fairness demands. ${ }^{\mathbf{3 4 0}}$

sss Doyle, 426 U.S. at 618.

sse 455 U.S. 603 (1982) (per curiam).

${ }^{337}$ See id. at 605-06.

3ss See id. at 607 ("A State is entitled . . . to leave to the judge and jury under its own rules of evidence the resolution of the extent to which postarrest silence may be deemed to impeach a criminal defendant's own testimony.").

${ }^{339}$ See Miranda, 384 U.S. at 475 ("If the interrogation continues without the presence of an attorney and a statement is taken, a heavy burden rests on the government to demonstrate that the defendant knowingly and intelligently waived his privilege against self-incrimination and his right to retained or appointed counsel.").

${ }^{340}$ One is also left to wonder why it is any less unfair to use defendant's postar- 
The result is that in Fletcher, as in Elstad, the defendant must show that some constitutional standard has been violated. What that standard might be, however, has become problematic. For judging by Fletcher, the Court appears wholly unconcerned with whether or not Miranda warnings are actually given. In this way, another triumph of SP-utility seems to be at hand: the counter-intuitive ("legalistic") presumption of innocence now bows to common sense, albeit common sense in the service of crime control ideology. It is the point of view that Bentham championed more than a century ago: only "knaves" hide truth behind rules of evidentiary exclusion. ${ }^{341}$

Thus, based on the common sense of Hale and Doyle, the accused's failure to exculpate himself after arrest is probative as to his guilt or innocence. This is true notwithstanding what was once thought of as the "inherent coerciveness" of custodial interrogation or whether in fact Miranda warnings have been given. As the Fletcher Court notes:

Common law traditionally has allowed witnesses to be impeached by their previous failure to state a fact in circumstances in which that fact naturally would have been asserted. Each jurisdiction may formulate its own rules of evidence to determine when prior silence is so inconsistent with present statements that impeachment by reference to such silence is probative. ${ }^{342}$

If Miranda threatened to render anachronistic the common law "tacit admissions" rule, ${ }^{343}$ based on OCS, Fletcher now seems to be heralding its resurrection.

However, the net gain to be derived from this development once again accrues not to common sense evidentiary rules, but to crime control ideology and its paramount goal of effective deterrence, the impulse behind the Court's steadily advancing deconstitutionalization of state confessions law. On the one hand, in these recent rulings the Court seems to foster the truth-searching dimension of the criminal process by making more evidence available than constitutional safeguards might otherwise allow. This trend also promotes the Court's new federalism. As the Fletcher majority puts it: "A State is entitled, in such situations,

rest silence against her when she believed (justifiably, in light of earlier Supreme Court assurances) that she had a right not to speak while in police custody. For a defendant to have to rely upon the police to activate her rights (rather than the Constitution itself) seems to stand Miranda on its head.

${ }^{341}$ See $5 \mathrm{~J}$. Bentham, supra note 20, at 216.

${ }^{342}$ Fletcher, 455 U.S. at 606 (emphasis added) (citation omitted).

s43 See Miranda, 384 U.S. at 468 n.37. 
to leave to the judge and jury under its own rules of evidence the resolution of the extent to which postarrest silence may be deemed to impeach a criminal defendant's own testimony." 344

Upon closer examination, the gain that the Court here grants to OCS and its corresponding community may be illusory. The real benefit goes to the advocates of SP-utility whose plea bargaining preferences are encouraged by decisions like Fletcher. Such encouragement derives from the increasingly attractive appearance of plea bargaining to defendants who, guided by the advice of counsel, find that as constitutional protections dissipate and additional evidence adverse to the defendant finds its way into the trial the potential advantages of proceeding to trial diminish. Conversely, the chance of conviction and the relative penalties therefrom increase. ${ }^{345}$ Given this uncertainty, the attraction of winning a known, lesser penalty, hammered out in bargaining between opposing counsel, is heightened. Thus, the Supreme Court's reversion to evidentiary trustworthiness talk, a type of discourse in which the lay public excels, is belied by the increasing privatization of the criminal process. To the extent that plea bargaining replaces the open criminal trial, counsel's ("expert") calculations about a crime's "worth" will come to replace the lay jurors' intuitive sense of moral blame (or mercy), along with the public edification process that jury trials uniquely allow. In their place, a private, esoteric conversation between legal experts will reign supreme. Not surprisingly, in view of the Burger Court's policy preferences, this very process is designed to advance the crime control goal of fact-based, fast, efficient, and detextualized justice. Moreover, it situates this bargaining process within a narrative universe, presumably made up of "self-interested," incessantly "calculating" actors, "trustworthy" officials, and "optimal" market conditions, which includes a presumed equality of bargaining power among the parties concerned. In this way, the Court ensures that utilitarian, cost/benefit discourse will triumph over other ways of thinking and talking about self, others, and social institutions in the law of confessions.

A final paradox associated with the ascendancy of SP-utility talk remains to be noted. As the Gourt leads the federal judiciary to a new era of a purportedly evidentiary common law, and as it increasingly withdraws itself from state court controversies in this area of the law, it is not, after all, the known pre-Brown evidentiary universe that we inherit. The prospect of conflicting versions of common sense no longer

s45 See supra notes 324-28. 
characterizes the rhetorical field before us. Notwithstanding the questionable virtue of such irresolvable disputes, ours is a different world. The crime control ideal, and the plea bargaining process that it champions, has set us apart.

Having explicitly constitutionalized plea bargaining, ${ }^{346}$ the Court has already set limits on what common sense can tell us. For one thing, it cannot say, as it did before Brown, that efforts to strike a deal with a defendant-for instance, promising more lenient, or threatening harsher punishments than a public trial might produce-make that defendant's "factual," plea-bargained admissions suspect and unreliable. ${ }^{347}$ For us today, inducing confessions in exchange for lighter sentences is a broadly accepted, constitutionally condoned practice. ${ }^{\mathbf{3 4 8}}$

Yet, if the federal rhetorical universe would deny the dialogical richness that history has provided, such is not the case on the state level, where the dominance of SP-utility talk remains only one of several narrative possibilities. Indeed, while SP-utility talk has captured some, many state courts have opted to follow a different path. ${ }^{349}$

Faced with a diversity of discrete criminal procedure dialects and the lessons of history about their respective judicial deployments, state courts today confront a rhetorical field that is rich with narrative possibilities. Mindful of this prospect, and the responsibilities state courts must now bear, ${ }^{350}$ the closing part of this work turns to an analysis of

${ }^{346}$ See Santobello v. New York, 404 U.S. 257, 258, 260-61 (1971) (guilty plea induced by promises is voluntary and may be used to convict defendant without trial); North Carolina v. Alford, 400 U.S. 25, 37-38 (1970) (same result when guilty plea induced by threats).

${ }^{347}$ See supra note 67 and accompanying text; $c f$. Spears v. State, 2 Ohio St. 583, 585 (1853) ("[T]he weight of authority establishes ... . [t]hat a confession induced by hope or fear, excited in the mind by the representations or threats of anyone, is not to be considered voluntary.").

${ }^{348}$ The plea bargaining process has been strongly criticized. See, e.g., Alschuler, Implementing the Criminal Defendant's Right to Trial: Alternatives to the Plea Bargaining System, 50 U. CHI. L. REv. 931, 931-37 (1983) (recognizing the almost universal acceptance of plea bargaining and proposing broad-sweeping reforms of entire system); Schulhofer, Is Plea Bargaining Inevitable?, 97 Harv. L. REv. 1037, 1106-07 (1984) (advocating the economic feasibility and preferability of using court trials instead of plea bargaining in Philadelphia).

348 See, e.g., Lee v. State, 422 So. 2d 928, 930-31 (Fla. Dist. Ct. App. 1982) (Although under Doyle, Jenkins, and Fletcher, defendant's due process rights were not violated since he was not read his Miranda warnings, "as a matter of state constitutional law, it is impermissible to comment on a defendant's post-arrest silence whether or not that silence is induced by Miranda warnings."); People v. Bethea, 67 N.Y.2d 364, 366, 493 N.E.2d 937, 938, 502 N.Y.S.2d 713, 714 (1986) (per curiam) (distinguishing Elstad as a matter of state constitutional law).

${ }^{380}$ See Brennan, supra note 156, at 548 ("T T] dime dinution of federal scrutiny and protection out of purported deference to the states mandates the assumption of a more responsible state court role."). 
dialogic competencies. Formal criteria for decisional legitimacy can be drawn from the dialogic typology described in Part I and illustrated above. These criteria derive from the virtues and vices of each of the discrete dialects of criminal procedure. Applying these standards can lead to greater clarity in the law of confessions by fostering increased self-consciousness about the ramifications of dialogic choosing. Such increased self-reflection would forestall the confusion that stems from unwitting dialectical switching and reduce the dangers associated with intentional strategies of dialogical dominance by which courts or legal advocates seek to disguise preferred norms or interests.

Finally, this rhetorical approach also provides a novel way of thinking and talking about our liberal democracy. It describes a view that culminates in the ideal of cross-dialogical reciprocity. According to this view, both legal practitioners, whether expert in prudent textual interpretation or in technical economic or philosophical analysis, and members of the lay public find their appropriate role, and, thus, may actively participate in the decisionmaking process. Part III will describe this ideal in the context of what this Article refers to as the institution of intrajudicial checks and balances among the discrete dialects of criminal procedure.

\section{Dialogic Competencies: Cross-Dialectic Reciprocity and The Institution of Intrajudicial Checks and Balances}

A society cannot exist, the past seems to teach us, unless it can somehow constitute itself as a rhetorical field, as what Dewey called "a public," and this means that we cannot exist without recognizing that some of our shared values carry an inescapable weight for all of us. Too often our way of talking about the increasing fragmentation of publics is to throw up our hands . . . I I think the command upon us is inescapable: we must build new rhetorical communities, we must find a common faith in modes of argument, or every institution we care about will die. ${ }^{351}$

The unique juncture that has been reached in the law of confessions may now be restated. While there are some mixed signs that the dialogic dominance of SP-utility, and its corresponding language of power, namely, cost/benefit talk in the service of crime control ideol-

${ }^{351}$ W. Booth, Modern Dogma ANd The Rhetoric of Assent 149-50 (1974) (footnote omitted). 
ogy, may be lessening slightly on the federal level, ${ }^{352}$ its ascendancy over other ways of thinking and talking remains well established. ${ }^{\mathbf{3 5 3}}$ The continued devolution of Miranda has ensured this result by disengaging confessions law from constitutional sources, thus leaving state confessions law to be governed by local evidentiary rules. Moreover,

352 That the dominance of SP-utility may be yielding to other forms of discourse can be seen, for example, in Moran v. Burbine, $106 \mathrm{~S}$. Ct. 1135 (1986). There, the failure of the police to allow an attorney obtained by defendant's sister to contact defendant while he was in police custody did not preclude defendant's in-custody statements, since they were made after defendant duly waived his Miranda rights. Justice O'Connor, writing for the majority in PI discourse, acknowledged that Miranda's safeguards were meant to "combat" or "dissipate" the "inherent compulsion" of in-custody interrogation and "thereby protect the Fifth Amendment privilege." Moran, $106 \mathrm{~S}$. Ct. at 1140,1143 . Reflecting the "prudent" accommodation that the Miranda interpretive framework embodies, Justice O'Connor noted: "[T]he decision as written strikes the proper balance between society's legitimate law enforcement interests and the protection of the defendant's Fifth Amendment rights." Moran, $106 \mathrm{~S}$. Ct. at 1143; see also id. at 1147 n.4 ("As any reading of Miranda reveals, the decision, rather than proceeding from the premise that the rights and needs of the defendant are paramount to all others, embodies a carefully crafted balance designed to fully protect both the defendant's and society's interests."). Justice O'Connor stated, probably taking note of Justice Douglas's potent critique of Michigan v. Tucker's, 417 U.S. 433 (1974), deconstitutionalization of Miranda, that "[the Miranda warnings'] objective is not to mold police conduct for its own sake. Nothing in the Constitution vests in us the authority to mandate a code of behavior for state officials wholly unconnected to any federal right or privilege." Moran, $106 \mathrm{~S}$. Ct. at 1143.

On the other hand, however, SP discourse may be yielding to the ad hoc, case-bycase analysis that Brown v. Mississippi's, 297 U.S. 278 (1936), intuitivistic due process discourse fostered in 1936. See, for example, Justice O'Connor's concluding remark in Moran: "We hold only that, on these facts, the challenged conduct falls short of the kind of misbehavior that so shocks the sensibilities of civilized society as to warrant a federal intrusion into the criminal process of the States." 106 S. Ct. at 1147-48 (emphasis added). See also Miller v. Fenton, 106 S. Ct. 445, 449 (1985) (holding that the constitutional standard state courts must apply in determining the voluntariness of a defendant's confession is the one provided by Brown: "This Court has long held that certain interrogation techniques . . . are so offensive to a civilized system of justice that they must be condemned under the Due Process Clause of the Fourteenth Amendment.").

${ }_{353}$ See Colorado v. Connelly, 107 S. Ct. 515 (1986), where notwithstanding Justice O'Connor's intimation to the contrary in Moran, Justice Rehnquist continues to refer to the exclusionary rule as a method of "substantially deter[ring] future violations of the Constitution," not as a constitutional rule. Id. at 521. The Court's continued tendency to mask individual preferences by enlisting putatively "neutral" ("scientific") authority is captured by Justice Burger's concurring opinion in Michigan v. Jackson, 106 S. Ct. 1404 (1986):

The urge for "bright-line" rules readily applicable to a host of varying situations would likely relieve this Court somewhat from more than a doubling of the Court's work in recent decades, but this urge seems to be leading the Court to an absolutist, mechanical treatment of the subject. At times, it seems, the judicial mind is in conflict with what behavioral-and theological-specialists have long recognized as a natural human urge of people to confess wrongdoing.

Jackson, 106 S. Ct. at 1411. 
with fewer abstract safeguards in place-and less emphasis upon deterrence in the service of safeguarding individual rights-to protect defendants from police procurement and use of incriminating statements or silence, ${ }^{354}$ more of such evidence adverse to the defendant is likely to find its way into the courtroom. ${ }^{355}$ Faced with the prospect of a more

354 See Florida v. Meyers, 466 U.S. 380, 385-86 (1984) (Stevens, J., dissenting) ("But we must not forget that a central purpose of our written Constitution, and more specifically of its unique creation of a life-tenured federal judiciary, was to ensure that certain rights are firmly secured against possible oppression by the Federal or State governments. . . . Yet the Court's recent history indicates that, at least with respect to its summary dispositions, it has been primarily concerned with vindicating the will of the majority and less interested in its role as a protector of the individual's constitutional rights.").

sss See, e.g., New York v. Quarles, 467 U.S. 649, 658 n.7 (1984) (noting that there is no constitutional imperative that requires the exclusion of evidence that results from emergency-induced police inquiry); Fletcher v. Weir, 455 U.S. 603, 607 (1982) (per curiam) (allowing use of defendant's postarrest silence to impeach defendant's credibility at trial where the record did not show Miranda warnings were given-thus encouraging police to withhold the warnings in order to make use of defendant's postarrest silence at trial); Sulie v. Duckworth, 689 F.2d 128, 131 (7th Cir. 1982) (finding it permissible to use defendant's postarrest request for counsel to impeach his insanity defense at trial), cert. denied, 460 U.S. 1043 (1983). In Sulie, Judge Posner, in a striking example of the SP-utility mode of discourse in action, attempted to evaluate "how much the exercise of the right to remain silent would be deterred if a suspect knew that a request for a lawyer could be used as evidence of his sanity." The answer immediately followed: "Not much, in our opinion." Id. at 130. Equally striking in Sulie is Judge Cudahy's dissenting opinion, which gives voice to the text-based PI viewpoint that opposes utilitarian calculations of the consequences that flow from deterrence at the expense of a particular defendant's rights. Judge Gudahy notes that "an analysis based on balancing deterrence of the constitutional right to counsel against the state's interest in testimony about seeking a lawyer is an approach clearly foreclosed to us by the Supreme Court," citing the rule in Doyle v. Ohio, 426 U.S. 610 (1976), that it is fundamentally unfair, as a matter of due process, to tell defendant that she has the right to remain silent and then to turn around and use her silence against her at trial. Sulie, 689 F.2d at 131-32. The Supreme Court has adopted Judge Cudahy's view with respect to the applicability of Doyle's due process analysis in this context for postMiranda silence. See Wainwright v. Greenfield, 106 S. Ct. 634, 641 (1986).

With respect to defendant's postarrest, but pre-Miranda silence or requests for counsel, however, state courts have not uniformly lined up behind the Supreme Court's crime control orientation. See, e.g., Lee v. State, 422 So. 2d 928, 931 (Fla. Dist. Ct. App. 1982) (holding as a matter of state constitutional law that it is impermissible to comment on a defendant's silence whether or not the silence is induced by Miranda warnings), petition denied, 431 So. 2 d 989 (Fla. 1983); Commonwealth v. Turner, 499 Pa. 579, 584, 454 A.2d 537, 540 (1982) (declining to hold, under the Pennsylvania Constitution, that existence of Miranda warnings or their absence affects a person's legitimate expectation not to be penalized for exercising the right to remain silent); Conway v. State, 625 S.W.2d 35, 39 (Tex. Ct. App. 1981) (under both federal and state constitutional law a defendant's postarrest silence may not be used for impeachment); State v. Brecht, 405 N.W.2d 718, 721-22 (Wis. Ct. App. 1987) (same under state constitutional law).

The reasons for reaching these differing results, however, have varied widely. The following rationales have been provided by the courts: 1) state constitutional grounds, namely, the individual's right against self-incrimination, see, e.g., Nelson v. State, 691 P.2d 1056, 1059 (Alaska Ct. App. 1984); People v. Jacobs, 158 Cal. App. 3d 740, 746- 
difficult battle at trial, and with the prosecutor's promise of a lesser, often substantially reduced, sentence in return for a defendant's pleading guilty to a lesser offense, it may not be surprising that plea bargaining, a private, expert-dominated, efficiency-oriented process gains ascendance. ${ }^{356}$

This state of affairs comports with the Court's understanding of the new federalism, for the deconstitutionalization process increasingly removes this area of the law from the purview of the federal judiciary. Put simply, localization and deconstitutionalization are part and parcel of the same judicial vision and philosophy.

While this philosophy, the dominant way of thinking and talking about confessions and silence on the federal level, has effectively shifted decisionmaking responsibilities from the federal to the state judiciary, its ascendancy on the state level remains problematic. Here, then, we witness the nature of the unique juncture referred to above. State courts now face a rhetorical landscape in which all three criminal procedure dialects represent genuine narrative possibilities. In this sense, it is a situation of both danger and opportunity.

Appreciating the nature of this juncture, and seizing the means by which to maximize the opportunity and minimize the danger will require an understanding of the ramifications of dialogic choices in judicial decisionmaking. This means that the discrete virtues and defects of each criminal procedure dialect and the effects of their deployment to resolve specific concrete conflicts must become a deliberate part of the decisionmaking process. Only by self-reflectively assessing their individual dialogic choices can decisionmakers take full responsibility for, and ensure the continued legitimacy of, decisional outcomes. Legitimacy in this context is to be understood as a structural principle of discourse. It describes a way in which the defects and virtues of one dialect may be checked and balanced by the virtues of another. It is this intrajudicial institution of checks and balances among the discrete dialects of crimi-

49, 204 Cal. Rptr. 849, 853-56 (1984); 2) fourteenth amendment due process grounds, see, e.g., People v. Givans, 166 Cal. App. 3d 793, 798-99, 212 Cal. Rptr. 762, 765 (1985); 3) state (common sense-oriented) evidentiary grounds, see, e.g., People v. McMullin, 138 Ill. App. 3d 872, 876-77, 486 N.E.2d 412, 415 (1985); People v. Conyers, 52 N.Y.2d 454, 557-60, 420 N.E.2d 933, 934-36, 438 N.Y.S.2d 741, 742-44 (1981); 4) a mixture of several grounds, see, e.g., Sanchez v. State, 707 S.W.2d 575, 578-82 (Tex. Crim. App. 1986) (citing state evidentiary law grounds and state constitutional privilege against self-incrimination); State v. Davis, 38 Wash. App. 600, 603-06, 686 P.2d $1143,1145-46$ (1984) (citing state constitutional due process and common sense grounds).

This diversity of rationales, along with the large number and the intensity of dissenting opinions which accompany many of these decisions, testify to the uncertainty among state courts in this area of the law.

${ }_{358}$ See supra notes $324-326,347-48$ and accompanying text. 
nal procedure that provides a remedy to the tyranny of dialogic dominance (at least in this area of the law, but possibly in others as well) by opening the way to enhanced cross-dialectical reciprocity.

Accordingly, an analysis of the discrete virtues and defects of the dialects typologically and historically described above is now in order. There are two points to be made. First, these dialects give rise to a structural principle of legitimacy. Second, the maximization of the dialects' discrete virtues and the minimization of their defects also gives shape to an aspirational ideal. That ideal, embodied in discourse itself, is the emergence of intersubjectively shared narrative realities. This understanding of discourse reflects what Robert Cover has referred to as the nomos, or "normative universe," in which we collectively dwell. ${ }^{367}$ Under this analysis, understanding, based on the model of communication as colloquy, ${ }^{358}$ emerges as a fundamental principle and a vitalizing impulse of our liberal democracy.

Upon reflection, we come to see that the "self-evident" meaning of manifest criminality and factual guilt, upon which the search for truth, or ordinary common sense (OCS) model of criminal process relies, is suspect. For one thing, the early case law shows that ordinary expectations about how criminals behave vary widely. Underlying these sharp divergences are manifestly opposed common sense understandings of human nature. For example, in one view, the pressures of custodial interrogation by police are sufficient to render a suspect's statements or silence untrustworthy and thus inadmissible at trial. From this perspective, the individual's natural impulse to clear herself of suspicion is a likely source of fabrication, leading her to say what the questioner wants to hear. ${ }^{359}$ An opposing view, however, holds that the natural tendency toward self-exculpation, when the opportunity to do so presents itself, renders a suspect's responses to police questioning (including her silence) entirely reliable. According to this view, "everyone knows" that the innocent person will seek, and be able, to explain away

${ }^{337}$ Cover, The Supreme Court, 1982 Term-Foreword: Nomos and Narrative, 97 HARv. L. REv. 4, 9 (1983) (A legal tradition "includes not only a corpus juris, but also a language and a mythos - narratives in which the corpus juris is located by those whose wills act upon it."). It also might share an affinity with Rawls's notion of "overlapping consensus." See Rawls, Overlapping Consensus, supra note 37, at 1 ; see also Sherwin, supra note 11, at 406-07 (noting that legitimate authority, unlike raw power, requires public and official acceptance of shared "ultimate values").

${ }_{358}$ See A. BiCkel, The Least Dangerous Branch 70, 206 (1962) (discussing the interplay of dialogue among the three branches of government); see also F. ROSENzWEIG, ThF StaR of REDEMPTION xiv (W. Hallo trans. 1971) (citing Wilhelm von Humboldt's observation that "true speech is colloquy"); Burt, Constitutional Law and the Teaching of the Parables, 93 YALE L.J. 455, 488-89 (1984) (discussing the conflicts that ensue when one attempts to secede from the dialogic process).

${ }_{350}$ See supra text accompanying note 64. 
the authorities' suspicion. ${ }^{380}$

Thus, notwithstanding the "self-evidence" of OCS expectations, upon reflection it appears that the truth claims to which OCS gives rise are complex and conflicting, and revelatory perhaps of diverse situational factors, such as geography, class, education, familial background, religion, and current events, to name only a few. Nor is it necessary for the OCS observer to know of such factors; indeed, OCS neither seeks, nor is it capable of systematically assimilating were it to find, a principled basis for its judgments.

Ordinary common sense, however, is not only divided over what guilty behavior looks like, it is also at a loss to explain or justify the notion of factual guilt itself. This omission should not be surprising. Upon closer inspection the "objective" truth of criminality to which OCS lays claim also is suspect. This is so because the criteria for blaming are never unalloyed with legal concepts of guilt. ${ }^{361}$ These are concepts that would raise a whole gamut of normative as well as descriptive issues, including how facts are classified, what facts may be properly allowed as evidence, who shall be allowed to speak, or what goals shall be pursued (e.g., incapacitation, rehabilitation, or retribution). In short, the self-evident claims of common sense belie a rich subtext of diverse historical, social, psychological, and other formative factors. ${ }^{362}$

Because the presuppositions, or conventional wisdom, on which OCS blaming rests lack clear and persuasive reasons explaining and justifying the basis for its judgments, as well as generalizable standards by which future correct outcomes can be discerned and predicted, judicial decisions that are dominated by this way of thinking and talking remain, at bottom, both subjective and ad hoc. No principled reason can

${ }^{360}$ See supra note 69 and accompanying text.

361 See Arenella, supra note 327, at 214 ("[T] he 'truth' [of guilt] cannot be discovered until some determination has been made about the actor's moral culpability."); Kelman, Interpretive Construction in the Substantive Criminal Law, 33 STAN. L. REV. 591, 591-92 (1981) (arguing that "interpretive construction" of concrete situations into substantive legal controversies is a vital phase of legal argument that undercuts the rationality of the other phase "rational rhetoricism"); $c f$. Schmidt, The Essential Status of Facts and Laws in Physics, 43 THE MoNist 161, 167 (1933) (advancing the idea that physical facts become "genuine" only when they are seen to obey a physical law).

382 See, e.g., I. Berlin, Vico and Herder: Two Studies in the History of IDEAs 37 (1976) ("Men make their own history, that is, they shape their own lives, both deliberately and without conscious intention, in response to physical environment and to unintended, 'providential' changes in their own natures. To understand their present condition, to be able to answer the most urgent problems which trouble men, political, moral, social, legal, religious, is to understand how these men came to be in a situation where alone these problems have arisen in this or that specific shape."). 
account for its dictates. Indeed, from this dialogic standpoint, inconsistency and unpredictability of decisional outcomes are all but inevitable. Yet, as a matter of judicial practice, decisionmaking that remains inconsistent and unpredictable not only violates the basic principle of equal justice (that similar facts require similar decisional outcomes), but it also renders impotent the ability of the law to impose order upon social action, for, without predictability, the decisionmaking process deprives individuals of any means by which to gauge the rightness or wrongness of their actions or the undesirable consequences that such actions might legally entail.

Thus, ordinary common sense-and, for similar reasons, rational (or intuitive) common sense-cannot provide a point of departure for judicial decisionmaking without seriously undermining consistency and predictability within the criminal process. Nor can it assure the continued force of basic (albeit counter-intuitive) institutional and text-based norms. Indeed, absent adequate reasons explaining and justifying its decisional outcomes, common sense, as a dominant mode of judicial decisionmaking, seriously threatens the legitimacy of adjudication. This is at least one of the lessons that the highly inconsistent, pre-Brown ${ }^{363}$ (OGS/evidentiary) decisions, like McMahon ${ }^{364}$ and Teachout, ${ }^{365}$ and the similarly divergent pre-Miranda (intuitive/due process) cases teach.

The dialect of Scientific Policymaking presents similar defects. On what basis can a particular decisionmaker justify and explain choosing a particular comprehensive view and the broad policy ends that it exclusively allows? More specifically, on what grounds can a court selfreflectively opt for the utilitarian goal of maximizing the deterrence of crime, even if this means sacrificing fairness or truth in the individual case, for the sake of prospectively achieving some greater goal, over the opposing Kantian comprehensive viewpoint, according to which preferred policy goals can never justify using the individual case or party as a means to achieve some "larger" end?" ${ }^{368}$ In short, the principle of autonomy, the Kantian's rational point of departure, is incompatible with the utilitarian's observations about human behavior, namely, that

\footnotetext{
s6s Brown v. Mississippi, 297 U.S. 278 (1936).

s64 People v. McMahon, 15 N.Y. 384 (1857).

ses People v. Teachout, 4I N.Y. 7 (1869).
}

${ }^{360}$ See generally A. MAcINTYRE, supra note 51, at 70 ("[W] rights are matched against claims appealing to utility or when either or both are matched against claims based on some traditional concept of justice, it is not surprising that there is no rational way of deciding which type of claim is to be given priority or how one is to be weighed against the other."). See supra note 355 (discussing the Sulie and Greenfield cases). 
humans are self-interested, calculating creatures. It is also incompatible with the utilitarian perception that the paramount goal, for which humans must strive, is to maximize, by virtue of some felicific calculus, the interest (or happiness, or wealth, or whatever content individual interest happens to bear) of the most people. Yet despite this fundamental opposition (indeed, underlying it), both comprehensive views lay claim to truths that are "self-evident" and thus beyond the realm of controversy.

Like the conflicting truths of common sense, the opposing versions of SP discourse manifest similarly antithetical views of human nature. On the one hand, humans are viewed as calculating self-interested creatures, susceptible of behavioral control via the positive reinforcement of deterrence. On the other hand, they are rational agents, capable of formulating universalizable rules or maxims geared to the mutual benefit of self and others. The different notions of the "good" and the "right" that each SP view entertains are no less divergent vis-à-vis the comprehensive policy goal of safeguarding the security of society on the one hand and the rational principle requiring the safeguarding of individual dignity and autonomy on the other. Moreover, SP's self-reflection does not persuasively justify or explain why the Kantian premise, say, is worthier of belief than its utilitarian counterpart. Indeed, the incompatibility of their fundamental presuppositions and the dogma of their respective methods (i.e., calculating utilities vs. universalizing rational volition) only compound the totalizing (and excluding) effect of their respective claims.

For example, we have observed that in recent years the interpretive framework of Mirand $a^{387}$ has been largely absorbed on the federal level within the utilitarian version of SP. From the standpoint of this dominant dialect, not only is the purpose of the criminal process selfevident (i.e., in accordance with the dictates of crime control ideology), but also the means by which this purpose is to be realized now attains a seemingly "scientific," or "neutral," status. In this way, the Court's putatively "objective" method belies the subjective nature of the policy preferences that inform and guide it.

In Tucker, ${ }^{368}$ Quarles, $^{369}$ and Elstad ${ }^{370}$ we witnessed a vivid portrayal of this development. ${ }^{371}$ One of the central issues that divides the majority from the dissenters in these cases is the former's tendency to

371 See supra notes 260-64, 283-95, 302-320 and accompanying text. 
characterize the deterrent effect upon police of excluding a defendant's statements from trial as speculative and unempirical, while the dissenters remain primarily concerned with the Court's failure to effectively deter perceived police violations of the Federal Constitution. Deterrence, then, tells us nothing about the policy or principle that its deployment is meant to advance. It as readily serves the search for truth and crime control perspective of Rehnquist, White, and Burger, as the individual rights perspective of Brennan and Marshall. As Kamisar has put it, "anyone can play [the cost benefit game]. Anyone can convert the process into something that merely gives him back whatever answer he feeds into it." ${ }^{\text {372 }}$ Yet, because the method itself looks neutral, the decisionmaker's normative presuppositions can be disguised by the way in which she chooses to characterize the costs and benefits at issue. In this way, underlying goals or values remain unexplained and unjustified.

Thus, while judicial decisionmaking, which takes a particular SP comprehensive view as its point of departure, may avoid the inconsistency of common sense's erratically totalizing, "localized" observations (presuming, that is, that one version gains dialogic ascendancy so as to impose its own unified viewpoint), that SP perspective nevertheless remains as essentially subjective, as devoid of self-reflectively explained and justified premises, as common sense. Here, too, therefore, charges of judicial subjectivity, or, more precisely, of subjective instrumentalism, ${ }^{373}$ and decisional illegitimacy remain potent.

In contrast to common sense, for which past and present are subsumed within the obvious now, and Scientific Policymaking, for which the now and the before foretoken a "self-evidently" preferred future, Prudent Interpretation takes the unknown present, manifest in the concrete conflict that impels judgment, as its point of departure. PI questions what it knows; uncertainty, rather than "self-evident" truths (whether reflectively or unreflectively held) is its dominant motif. Upon reflection, PI turns within and without. Without are inherited texts and procedures which help to structure and assess (i.e., give meaning to and normatize) competing narratives and conflict resolutions. Within are presuppositions and the meanings that personal histories and a particular culture provide. These meanings define the interpreter's horizon of

${ }^{372}$ Kamisar, supra note 199, at 645; see also id. at 646 ("How does one balance 'privacy' (or 'individual liberty' or 'personal dignity,' or call it what you will) against the interest in suppressing crime (or 'law and order' or 'the general welfare,' or call it what you will)?").

${ }^{373}$ See Woodard, The Limits of Legal Realism: An Historical Perspective, in $\mathrm{H}$. PACKer \& T. Ehrl.ICH, supra note 33, at 339. 
understanding, but may change as the meanings of specific texts, set within specifically contextualized dramas, play upon and test the presuppositions that guide and shape the interpreter's understanding of self, others, and social institutions.

For these reasons, PI does not aspire to certainty, much less universality. Events are too unruly, as are the textual interpretations to which concrete events give rise. In its ongoing search for meanings, PI questions not only what it knows (i.e., the cultural heritage of the law), but also how best to understand the concrete conflicts that trigger the need for judgment. In this way, the stability of meaning and of events that common sense and SP discourse presuppose are not a part of the discursive reality of PI. For PI there is a constant dialectic between event and interpretation. What is current affects what is past, and helps give shape to what will make sense in the future.

Because PI's interpretive sense is rooted in the particularity of a concrete conflict, the decisionmaker who engages this discourse as her point of departure must identify and apply those legal, text-bound precedents that are relevant to it. Having isolated the relevant topics of law, the decisionmaker must then self-reflectively interpret the texts which explicate that topic. She must then apply them to the situation in question, explaining and justifying both their relevance and propriety. Because interpretation proceeds by the provision of reasons for particular meanings in particular circumstances, PI's point of departure, unlike SP's or OCS's, is marked by controversial (not "self-evident") discourse. From this dialogic perspective, one may self-reflectively account for both the basis for a particular interpretive framework and the method of explaining and justifying a particular interpretive application. Comprehensive principles, such as the one proffered in Miranda, may yield to more particularized, fact-sensitive analysis, such as the intuitive, case-by-case method advocated by the Miranda dissenters, or may fall still-born from the high bench, as was the case in Bram. ${ }^{\mathbf{3 7 4}}$ Absent determinate meanings at the outset, however, either in the form of reflexively applicable ("self-evident") rules or antecedently stipulable ("self-evident") premises, such uncertainty cannot be helped. No final resolution can be expected. ${ }^{376}$ As Toulmin has suggested, it is the give and take inspired by controversy that sustains a professional commu-

374 Bram v. United States, 168 U.S. 532 (1897).

376 See J. WHITE, supra note 4, at 273 ("Law works by a process of argument that places one version of events against another and creates a tension between them ... To conceive of the law as a rhetorical and social system, a way in which we use an inherited language to talk to each other and to maintain a community, suggests in a new way that the heart of law is what we always knew it was: the open hearing in which one point of view . . . is tested against another."). 
nity. ${ }^{376}$ It is therefore not the presence of controversy, but rather its extent and quality with which participants in the decisionmaking process need be concerned.

In cases such as Malloy ${ }^{377}$ and Miranda, the Court overcame the radically divergent decisionmaking engendered by the intuitive common sense of due process jurisprudence. Self-reflectively plotting the meanings that particular texts allow, the Court's interpretive decisionmaking engendered controversy. Such controversy is crucial, however, as a means of openly airing competing interests and values and of presenting persuasive reasons for preferring one point of view over another. To the extent that preferred meanings are hidden from view, as a matter of common sense or "self-evident" principles, controversy is stifled.

Because meanings are uncertain, the interpreter must be prepared to accept as meaningful that which lay beyond the given horizon of her own self-consciously entertained (pre)judgments. ${ }^{378}$ This requires a willingness to encounter the strange: to make conscious what was unconscious, or to entertain as possible a presupposition held by others. Whether one is examining the soundness of one's own partialities or those of another, the need to give reasons for structuring the meaning of events, or for characterizing individuals or texts or institutions in one way as opposed to another, becomes part and parcel of the discursive process. In this way, the self-reflective search for meaning(s) eschews the tyranny of dogmatism.

While this description may reflect an ideal type, it is the touchstone for measuring the quality of controversy in a particular case. Indeed, for the reasons outlined above, PI alone among the three dialects serves as a legitimate point of departure for judicial decisionmaking. Its uncertainty makes plain the need for self-reflective persuasion as well as the prudence of accommodation among competing interests or values.

From this perspective, then, the criminal process proceeds as a constant, critical re-encounter with the historical texts that (pre)shape and (pre)form the interpretation of concrete conflicts. In this sense, PI discourse privileges the technical and strategic expertise of judges. The conventional wisdom of the lay public (e.g., the jury's ordinary common

376 See S. ToulmiN, supra note 15, at 261-81, 499-500 (discussing the controversy that has developed and the interplay of differing historical approaches to human understanding).

${ }^{377}$ Malloy v. Hogan, 378 U.S. 1 (1964).

${ }^{378}$ See H. GADAMER, supra note 4, at 273 ("[T]he horizon of the present is being continually formed, in that we have continually to test all our prejudices. An important part of this testing is the encounter with the past and the understanding of the tradition from which we come. ... Understanding .... is always the fusion of these horizons [of present and past]."). 
sense) and the esoteric (extrajudicial) expertise of Scientific Policymakers (e.g., privileging economists' cost/benefit analysis or philosophers' talk about deontology) retain their singular roles as ways of assaying the prudence of particular interpretive judgments. They cannot, however, do the work of interpretation itself. It is the judge, aided by the persuasive narratives of others (lawyers, scholars, and other judges), in light of a shared repertoire of procedures and a common repository of texts, who must ultimately account-and who will be held accountable-for interpreting and applying specific texts in a given case.

If, for reasons suggested above, PI provides a legitimate point of departure for judicial decisionmaking, this does not mean it is without significant defects. Indeed, left unchecked and unbalanced by other modes of discourse, these defects risk giving rise to a discrete form of tyranny. Paradoxically, the defects of PI not only reflect limitations that are built into this discrete form of legal discourse, but they in fact grow out of PI's idiosyncratic attempt self-reflectively to compensate for them. Such compensation takes shape in efforts to assimilate the virtues of other ways of thinking and talking. These efforts cannot succeed. Indeed, it is by this process of overreaching that PI's virtues are apt to be subverted by the very limitations it would deny. If this self-aggrandizing tendency were to prevail, OCS and SP would be reduced to silence. It is, however, the singular virtues of OGS and SP that rescue PI from itself.

Because PI self-reflectively interprets and applies inherited texts within particular contexts, those engaged in this mode of discourse will know its origins but not its future consequences. Who can predict what new meanings unprecedented controversies might engender? How can general standards emerge from a mode of discourse whose origins remain localized, a dialect that remains tied (as both constituent and constituting agency) to the concrete conflict and inherited text whose meanings a particular interpretation strives to make persuasive?

But the difficulties PI faces in trying to escape from particularized meanings, and in generating predictable and comprehensive standards, are not its only defects. It must also come to grips with its own countermajoritarian threat by confronting the following question: how are counter-intuitive principles (such as the one that Miranda found embodied within the fifth amendment privilege against compelled self-incrimination) to be made palatable to the lay public? Put differently, how is the Court to overcome the danger of countermajoritarian rule, a danger inherent in the Court's limited power? For should public com- 
pliance cease, the Court's work is done. ${ }^{379}$

In response to the latter dangers, the temptation is to disguise the controversy that interpretation gives rise to by deploying formal strategies of dominance. Recall here Malloy's attempt to attribute to history its own significant rereading of relevant case law. Recall, too, $\mathrm{Mi}$ randa's attempt to assimilate into the lexicon of its constitutional interpretive framework untested empirical assumptions about the effect $\mathrm{Mi}$ randa warnings would have upon police investigation and the willingness of defendants to continue to provide in-custody confessions. In these cases, albeit in different ways, the Court sought to escape both controversy and the burden of providing persuasive reasons for its opinions, by resorting to tactics of disguise, which this Article has described as strategies of formal dominance.

PI's inability to meet the ordinary expectations of common sense accounts, at least in part, for its strategic evasion of controversy. It avoids rather than uses controversy to provide persuasive reasons for public compliance. Only the latter, however, fulfills its public edification function, possibly rendering a decision more "prudent" in the process. Similarly, it is the inability of PI to meet the comprehensive predictability demands of SP that gives rise to its second discrete defect. Recall here Miranda's fateful attempt to accommodate the concerns of the dissenters regarding the restrictiveness of the Court's abstract interpretive principle at the risk of eviscerating the principle itself. According to a dissenting view, Miranda's rigid rule would hamper future law enforcement by imposing upon police a "constitutional straitjacket." In an effort to defuse this criticism, the majority invited alternative safeguards that would equally serve the values that were at stake: namely, protecting the autonomy and dignity of suspects in police custody. This accommodation appeared to distance the Miranda warnings themselves from the constitutional text that authorized them in the first place. In this way, the majority jeopardized the constitutional principle that lay at the heart of its analysis-a vulnerability that opponents such as Burger and Rehnquist wasted no time in exploiting.

Miranda's tactical mistake, however, if it was that, did not lie in its effort to achieve a prudent compromise between its interpretive framework and the crime control perspective. Indeed, this effort reveals one of PI's great strengths-the virtue of prudence that underlies the

379 See Kronman, supra note 31, at 1581-82 (Bickel describes the tension between abstract principle and public consent as "Lincolnian." According to Kronman, judicial "wisdom" or "understanding" may be able to allay this tension by "picking the strategies of accommodation most likely to succeed from one situation to the next."). 
strategically accommodating approach to which it aspires. ${ }^{380}$ If the $M i$ randa compromise reveals a weakness, it lies in the majority's failure to realize that prudence has a corresponding virtue, namely: courage. Accommodation, in order to offset the countermajoritarian threat and the associated danger of public or official noncompliance, must not strive to unduly defuse the controversy that PI inevitably spawns. In this sense, Miranda's error might well be its failure explicitly to surround its accommodating strategy with adequate cautionary remarks. Such remarks would have left no doubt that accommodation was but an offshoot of, that is, ancillary to, its constitutional interpretative framework. The framework itself would appear more clearly as the source of authority for procedural guidelines in addition to the ones specifically authored by the Court.

Here, the virtues of SP-utility talk re-emerge, although in a different light. Rather than serve as a point of departure, SP provides a necessary corrective of a PI defect. Specifically, SP talk redresses PI's inability to weigh systematically the consequences of its interpretive principle and determine where it might lead in future decisionmaking. Thus, while still questionable as a legitimate source of (putatively selfevident) comprehensive social goals, SP's systematic policy talk has a valuable role to play. By treating a localized interpretative outcome as if it were universal or paradigmatic, that is, by using the interpretation as a hypothetical model for future decisionmaking, the consequential implications of a particular interpretation can be practicably assessed. ${ }^{381}$

380 See id. at 1609 ("[P]rudentialism not only asserts, in general terms, that legal and political controversies are contextually located within institutions and traditions capable of self-revision, but also attaches a positive value to change of a particular sort-gradual change carried out, as Bickel was fond of saying, at the retail level."); $c f$. Moran v. Burbine, 106 S. Ct. $1135,1143,1147-48$ \& n.4. (1986) (Justice O'Connor characterizes Miranda as a carefully crafted balance of competing interests.).

${ }^{381}$ See Ingram, Hermeneutics and Truth, in Hermeneutics and Praxis 49 (R. Hollinger ed. 1985) ("The projection of a universal history is always provisional, for it is subject to revision in light of new circumstances."). Compare this with Rousseau's reliance upon the "state of nature" not as an historical "truth" but rather as the basis for a regulative ideal. See E. CAssirer, The Philosophy of The ENLightenMENT 271 (1955) ("[Rousseau] does not consider the state of nature as a mere fact or as an object of contemplation and nostalgic longing; he employs this concept rather as a standard and norm according to which he can show what in the present state of society is truth and what illusion, what is morally obligatory law and what is mere convention and caprice."). In perhaps a similar vein, Plato-notwithstanding his mistrust of poetic insights unchecked by the give and take of "dialectic"-employed mythopoetic narratives in his efforts to understand the nature of "virtue" or "love," or "the true art of persuasion." See, e.g., Plato, Phaedrus 50, 67-70 (W. Helmbold \& W. Rabinowitz trans. 1956) (using the tale of King Thamus of ancient Egypt and Theuth, stand-ins respectively for the Greek dialectition and sophist, to argue against memorization, which invites the "delusion" of learning knowledge, as opposed to "real judgment," 
The key here is that SP re-emerges not as a source of antecedently defined normative premises, but rather as a concretely-based critical method. Incompatible comprehensive views-reflecting both the Kantian focus upon individual dignity (based on universalizable principles of rational volition) and the utilitarian focus upon deterrence (as the "paramount" goal of crime control ideology)-may thus openly contend for the interpreter's commitment. It is this mediating task that a particular comprehensive view is singularly unable to perform. Only PI provides the rhetorical field in which self-reflective prudent accommodation can occur. Operating as a dominant dialect, a particular SP viewpoint can only strive to translate incommensurable and incompatible values into its own exclusive idiom-a task that cannot succeed.

As a critical method to check and balance the limitations of PI discourse, Scientific Policymaking will help to ensure that the possible decisional consequences flowing from a particular interpretive outcome will not be seriously detrimental to either SP viewpoint (i.e., that it will not ignore concerns about either consequential costs or individual dignity). ${ }^{\mathbf{3 8 2}}$ By the same token, competing policies or principles can enter the controversy that interpretive discourse spawns as contestable, rather than "self-evident" claims. In this way, SP presuppositions become a part of persuasively reasoned discourse ${ }^{383}$ and avoid the (covert) totalizing effect of a single, dominant-subjectively preferred, but putatively "self-evident"-comprehensive view.

While reliance upon SP as a critical method may check and balance one of PI's defects, this still leaves untreated the countermajoritarian dangers to which PI discourse also gives rise. PI's second defect, namely the effort spawned by PI's own prudent, but timorous, impulse to defuse controversy in order to meet ordinary common sense expecta-

which allows knowledge through dialectical reasoning-the "living, animate discourse of a man who knows.").

${ }_{382}$ See Kronman, supra note 31, at 1569-70 (Bickel "considered the overly philosophical insistence on principles for their own sake . . . as the antithesis of prudence." Bickel further maintained that while "no good society can be unprincipled . . . "no viable society can be principle-ridden'." He feared that "abstract theories and moral imperatives" have a "tyrannical tendency"." (citations and footnotes omitted)); see also M. Adler, Art and Prudence: A Study in Practical Philosophy vii (1937) ("There can be no wisdom in action without principles. There can be no determination of action by philosophy without the supplementation of casuistry in the application of principles.").

${ }^{383}$ See Henkin, Morals and the Constitution: The Sin of Obscenity, 63 Colum. L. REv. 391, 411-12 (1963) ("The domain of government, it is suggested, is that in which social problems are resolved by rational social processes, in which men can reason together, can examine problems and propose solutions capable of objective proof or persuasion, subject to objective scrutiny by courts and electors. . . . [P]erhaps the Constitution denies to government and to majorities the domain of the non-rational, leaving private morality to Church, and Home, and Conscience."). 
tions, still remains intact. It is here that the singular virtues of common sense discourse and its corresponding dialogic community re-emerge alongside SP to check and balance the deployment of PI discourse.

Once OCS is eliminated as a point of departure for judicial decisionmaking, its virtues and defining role within the criminal process come into view. While unpredictability and subjectivity are hardly judicial virtues, as Brown and its progeny made clear during the era of due process jurisprudence, this is not to say that intuition and common expectations must therefore be barred from the criminal process. Instead, they must be properly situated within it. For example, ordinary common sense may operate as a function of prudence, to gauge public and/ or official compliance with a particular interpretive principle. As a point of departure for judicial decisionmaking, the inconsistency and ineradicable subjectivity of common sense makes its role problematic. However, it is precisely its lack of expertise that suggests what the proper role of common sense in the criminal justice system should be. Indeed, if common sense is to serve as a genuine check upon PI's (interpretive) and SP's (comprehensive) forms of tyranny, it must do so from outside of their respective expert communities. Accordingly, the lay public remains the source and the stronghold of common sense decisionmaking. In this respect, the institution of the public jury trial provides an important check upon the dangers that countermajoritarian discourse poses. If a particular SP comprehensive view hardens events and principles to suit antecedently defined premises, and, if PI, for its part, molds the normative and narrative possibilities of discourse to suit its specifically localized, text-based interpretations, jurors are bound by no such limitations. Their role is to determine the nature of the conflict at hand and to ascertain who if anyone is to blame. The lay public is particularly well suited to fulfill this function. ${ }^{384}$

In order to assess a particular conflict situation, one must ascertain what really happened: who acted in what ways, at what times, for what reasons? This means one must determine whether the accused as well as various witnesses who may testify are telling the truth, or only some or even none of it. It also means one must answer such questions as: was the defendant acting under the influence of an insane delusion or did he knowingly intend the consequences of his action? In short, one must decide whether, under the circumstances, the accused should be

384 See P. Devlin, Trial By Jury. 115 (1956) (Common sense "is the only virtue with which a jury is necessarily equipped."); Arenella, supra note 327, at 215 (a jury verdict represents a "community's sense of justice"); White, Making Sense of Criminal Law, 50 Colo. L. Rev. 1, 20-26 (1978) (The jury is "particularly competent at the practice of blaming."). 
blamed, even if the acts attributed to him actually occurred.

This complex of issues-often involving mixed questions of law and fact-is raised by the need to make sense of a particular set of stories, to assemble coherently various and, in all likelihood, conflicting pieces of evidence; to construe argumentation by opposing counsel; and to fairly apply legal standards of guilt. Out of the innumerable separate judgments made in response to these questions, a concrete situation, with its own particular actors and issues, is defined. Only then is the type of situation, or the recurrent problem that it represents, available for "topical" and interpretive legal analysis and reflection.

Admittedly, in the process of defining the conflict situation, certain judicial choices regarding which legal standards are to be applied, or which proposed defenses or sources of evidence are permissible, will be made on the basis of specific judicial knowledge and training. Such choices clearly are susceptible to rational debate, and the appellate process is the normal forum in which such controversies are resolved. The fact remains, however, that no similar expertise is required to assess the evidence that is admitted or to apply the legal standards that are deemed appropriate in the course of attributing blame. It is here that the "unreflective" (or "unprincipled") features of the criminal process dovetail with the discrete virtues of common sense discourse. It is precisely here that particular forms of expertise, rather than providing assistance, may pose an obstacle. This is so because the type of judgment that such matters require-judgments that are based on ordinary observations and common wisdom and that reflect complex, radically differing and always "obvious" (albeit unexplained) ways of making sense of reality-are not the kind we generally expect judges to make.

As we have, seen, such common sense judgments rest upon what "everyone knows" about how people behave and what that behavior means. Judgment of this kind embodies what Geertz calls "local knowledge," or colloquial reason. ${ }^{385}$ It represents the community's collective, or "common" common sense. Thus, while it is true that judges, simply because they are judges, must not leave aside their common sense when they mount the bench, ${ }^{\mathbf{3} 8}$ common sense as the normal point of departure for judicial decisionmaking is troublesome. The failure of common sense persuasively to explain and justify the bases for its claims undermines predictability and raises the taint of judicial relativism. However, while a court's subjective impressions, uncommitted to self-reflective reasoning and inaccessible to subsequent review, threaten the stability

s8s See C. GeERTZ, supra note 16, at 215-19.

${ }^{388}$ See Watts v. Indiana, 338 U.S. 49, 52 (1949) ("[T]here comes a point where this Court should not be ignorant as judges of what we know as men."). 
and legitimacy of judicial decisionmaking, the jury's failure to provide a principled basis for its conclusions is an accepted part of its function. ${ }^{387}$ Moreover, the jury's broad discretion makes sense.

For example, determinations of credibility, based on the jury's observations of a witness's demeanor at trial, are hardly reducible to rational principles of judgment: rather, they are the fruits of common experience and sensibility. In addition, the jury's broad discretion allows jurors to act upon what they believe is right, even when to do so contravenes specific legal requirements. It is in this context that juries may even nullify the law by refusing to apply it to a particular defendant if they feel that to do so would be unjust under the particular circumstances. ${ }^{388}$

This function provides what Arenella has called a "safety valve review" of the legislature's original decision. ${ }^{389}$ That is, if the legislature's decision to make certain acts criminal ceases to comport with the community's sense of justice, that original decision can be checked by changing community standards. In this sense, every jury verdict manifests a "legislative" feature ${ }^{380}$ The reluctance of legislators to change the law in accordance with changing values may thus be overcome. Moreover, the community's refusal to convict provides important feedback to the legislative process. ${ }^{391}$ Finally, while it is true that the power of the lay publics may be abused, ${ }^{392}$ extreme cases of this kind

${ }^{387}$ See United States v. Ogull, 149 F. Supp. 272, 276 (S.D.N.Y. 1957) ("To ask the jury special questions might be said to infringe on its power to deliberate free from legal fetters; on its power to arrive at a general verdict without having to support it by reasons or by a report of its deliberations ...."), affd sub nom. United States v. Gernie, 252 F.2d 664 (2d Cir. 1958).

${ }^{388}$ See P. Devlin, supra note 384, at 160 ("[The jury] gives protection against laws which the ordinary man may regard as harsh and oppressive. . . . [I]t is a protection against tyranny [and] an insurance that the criminal law will conform to the ordinary man's idea of what is fair and just. If it does not, the jury will not be a party to its enforcement."); see also Broeder, The Functions of the Jury: Facts or Fictions, $21 \mathrm{U}$. CHI. L. Rev. 386, 386 (1954) ("More than any other institution, the jury has been the symbol of a democratic people zealous of freedom and afraid of centralized government power."). But see United States v. Dougherty, 473 F.2d 1113, 1133 (D.C. Cir. 1972) (noting that the "so-called right of jury nullification ... risks the ultimate logic of anarchy.").

${ }^{389}$ Arenella, supra note 327 , at 215-16.

${ }^{380}$ See United States v. Levine, 83 F.2d 156, 157 (2d Cir. 1936) ("[T]he verdict of the jury is not the conclusion of a syllogism of which they are to find only the minor premiss [sic], but really a small bit of legislation ad hoc . . ...").

301 It also provides the means by which legal defenses (such as justification and excuse) are most practicably assessed and applied-a process that plea bargaining endangers. See supra note 325 and accompanying text.

${ }_{302}$ For instance, juries may act in ways that promote community prejudice. $C f$. Broeder, supra note 388, at 413-17 (noting that "[f]rom the time of the Alien and Sedition Acts, the government's attempted inroads on civil rights seem to have received the enthusiastic support of jurors"). 
may be judicially modified. ${ }^{393}$

It is questionable whether judges are as well suited to fulfill the particular judgmental tasks that juries perform. ${ }^{394}$ For example, with respect to "blaming," White has observed:

[The jury] is more competent at this practice than any one man could be, for collective judgment reduces idiosyncrasy; and it is more expert than any professional, for whom each case tends to be just one of many, the material upon which his profession or the bureaucratic institution of the criminal law acts. ${ }^{380}$

Notwithstanding the belief of those such as Cardozo who claim that judges can adequately reflect the sentiments of the community, ${ }^{396}$ it is plausible that representatives of the community are themselves a more reliable source of authority on this matter. Judges are more likely simply to project their own values onto the community mind they set out to read.

s8s See Pope, The Jury, 39 Tex. L. Rev. 426, 447 (1961) (noting that "judges may exercise corrective control over juries in cases of misconduct on [sic] corruption"). For example, a judge must direct a verdict of acquittal if she finds that reasonable minds would entertain doubt as to the defendant's guilt. See Nesson, The Evidence or the Event?: On Judicial Proof and the Acceptability of Verdicts, 98 HARv. L. REv. 1357,1369 n.36 (1985) (discussing the standard for directed verdict); see also James, Sufficiency of the Evidence and Jury-Control Devices Available Before Verdict, 47 VA. L. REv. 218, 218-27 (1961) (same).

Postconviction remedies may also be used to avoid the consequences of a jury conviction. See Note, State Post-Conviction Remedies, 61 Colum. L. Rev. 681, 682-96 (1961) (discussing the availability of writs of habeas corpus and coram nobis).

State actions that promote prejudice may also prompt judicial intervention. See, e.g., Taylor v. Louisiana, 419 U.S. 522, 526-31 (1975) (state restrictions that resulted in disproportionately fewer women on jury held unconstitutional).

s94 See Duncan v. Louisiana, 391 U.S. 145, 156 (1968) (noting that jury trials provide a "safeguard against ... the compliant, biased, or eccentric judge").

395 White, supra note 384 , at 26 . One commentator has noted:

If a clever man is left to decide by himself disputed questions of fact he is usually not content simply to decide each case as it arises. He constructs theories for the decision of analogous cases. These theories are discussed, doubted, or developed by other clever men when such cases come before them. The interest is apt to center, not in the dry task of deciding the case before the court, but rather in the construction of new theories, the reconciliation of conflicting cases, the demolition or criticism of older views. The result is a series of carefully constructed, and periodically considered rules, which merely retard the attainment of a conclusion without assisting in its formation.

P. Devlin, supra note 384 , at 148-49 (quoting $1 \mathrm{~W}$. Holdsworth, History of ENGLISH LAW 358 (3d ed. 1922)).

${ }_{388}$ See B. Cardozo, The Nature of the Judicial Process 88-89, 108-13 (1957) (discussing the tension between objective and subjective standards and positing that a judge is "under a duty to conform to the accepted standards of the community"). 
Finally, it is the jury alone that may ensure the independence and quality of judges. This proposition follows from the widespread practice of executive appointment ${ }^{387}$ and the well known fact that historically, in Devlin's words, "the executive has found it much easier to find judges who will do what it wants than it has to find amenable juries." "398 In short, the jury is an effective counter-balance to executive dominance of the judiciary. ${ }^{389}$ In light of the foregoing analysis, then, the countermajoritarian danger that courts and legislators pose-as a result of either imprudent and unpersuasive or outright deceptive rhetoric on the one hand, or detached and systematized, putatively "scientific" dogma on the other-may be checked and balanced by the lay publics that make up our jury system. Their view, which reflects a diversity of backgrounds and experience, offers a more reliable embodiment of the community's values than a single, perhaps idiosyncratic, judicial perspective could provide. The jury's presence also allows the criminal defendant to tell her own story to those who speak the same language. ${ }^{400}$ The nature of the institution of intrajudicial checks and balances among the three discrete dialects of criminal procedure may now be apparent. Because it eschews the narrowing, or dialogic silencing effect, which reliance upon putatively "self-evident" truths or comprehensive policies produces, the dialect of PI provides a legitimate point of departure for judicial decisionmaking. Its openness to horizons of meaning other than its own, ever mindful of the possible error its own presuppositions may disclose, allows and encourages a constant, critical (re-)encounter with, and revitalization of, inherited texts. From the PI perspective, while these texts are situated within history, they

s07 See U.S. ConST. art. II, § 2 ("[The President] shall nominate, and by and with the Advice and Consent of the Senate, shall appoint . . . Judges of the Supreme Court, and all other Officers of the United States, whose Appointments are not herein provided for .....").

308 P. Devlin, supra note 384, at 159.

s89 As de Tocqueville put it, "The jury is both the most effective way of establishing the people's rule and the most efficient way of teaching them how to rule." A. DE TocQueville, Democracy in America 254 (J. Mayer \& M. Lerner eds. 1966). According to de Tocqueville, in addition to spreading "respect for the courts' decisions and for the idea of right," juries also embody numerous other virtues. For instance, they "teach men equity in practice;" they "teach each individual not to shirk responsibility for his own acts;" and they "invest each citizen with a sort of magisterial office; they make all men feel that they have duties toward society and that they take a share in its government." In short, in de Tocqueville's view, the jury is a "free school" in the art of republican self-government. He concludes that few other public institutions are as "wonderfully effective in shaping a nation's judgment and increasing its natural lights." Id. at 252-53.

${ }^{400}$ See J. WHITE, supra note 4, at 265 ("He has the right to a jury, to ensure that he will have an audience that will understand his story and speak his language." (footnote omitted)). 
nevertheless must find their meanings within current, localized contexts. ${ }^{401}$

If PI overcomes the tyranny of the haphazardly totalizing truths of common sense, or the systematically totalizing truths of SP, its unique defects nevertheless pose a tyrannizing potential of their own. Thus, the critical method of SP re-emerges to check and balance PI's localized (incomprehensive and uncertain) decisionmaking by projecting into the future its consequential implications. Similarly, ordinary common sense re-emerges to check and balance the tyranny of judicial expertise, whether that tyranny comes in the form of SP's antecedently defined (albeit diametrically opposed and subjectively preferred) premises or in the form of PI's strategic efforts to meet and assimilate common sense expectations at the cost of interpretive principle. OCS offsets the court's countermajoritarian tendency by taking upon itself the burden of subjective-which is to say, unreflective and unprincipled (or intuitive)-judgments about such matters as credibility, blameworthiness, and the like. Because the lay publics are better suited than judges to make these kinds of common sense judgments, their participation in the criminal process should never be foreclosed by deference to particular forms of judicial (or extrajudicial) expertise.

Within this network of checks and balances among the discrete dialects of criminal procedure, the singular virtues of each discrete dialect find their proper place within the criminal process. Moreover, the imperfections of each form of discourse, and the unique dangers to which each unconstrained defect gives rise, call forth the need for a careful interweaving of all three dialogic forms and, concomitantly, for the active participation of their respective dialogic communities. In this way, the dangers of dialogic dominance may be curtailed, even as crossdialogic reciprocity, so vital to the practice of participatory democracy, may be fostered.

The dominance of different criminal procedure dialects at different points in history describes a distinct pattern within the law of confessions. The foregoing dialogic survey has traveled from ordinary common sense about evidentiary trustworthiness, focusing primarily upon the search for truth and ordinary expectations about manifest "factbased" criminality, to rational common sense about due process, which

401 See C. GeER'Tz, supra note 16, at 215 (describing law as "local not just as to place, time, class and variety of issue, but as to accent-vernacular characterizations of what happens connected to vernacular imaginings of what can"); $c f$. S. Toulmin, supra note 15, at 499-500 (recognizing the need to refine our intellectual, judicial, and technical strategies and procedures on the basis of human experience in different cultures and historical periods). 
involves ad hoc intuitions of fairness in the particular case. It then examined self-reflective, contextualized interpretation, by which courts seek prudently to accommodate competing interests or values within a particular interpretive framework. Finally, this Article provided examples of a self-reflective, decontextualized cost/benefit analysis by which courts seek to realize the putatively paramount criminal process goal of crime control by maximizing the efficiency and effectiveness of deterring criminal activity.

The law of confessions may now be at a critical juncture. Given the ascendancy of the Supreme Court's new federalism, notwithstanding the dominance of SP-utility discourse on the federal level, it remains for the state courts to determine whether to follow the Supreme Court's lead or to strike out on paths of their own choosing. When choosing, the courts confront three discrete dialogic possibilities, each with its own way of understanding self, others, and social institutions, and each with its own tendency to empower one dialogic community at the expense of others. This Article has argued for increased self-reflectiveness about dialogic choosing in the hope that this will aid the courts in deciding their own paths. For, without it, the ramifications of particular dialogic commitments will go unperceived, and, consequently, the dangers of dialogic dominance and distortion will remain unchecked and unbalanced.

Applying some of the insights that the foregoing dialogic analysis has developed to the law of confessions, the following concrete recommendations are offered:

1) Courts should confront Miranda's interpretive framework directly, without disguise; whether the fifth amendment privilege protects the individual accused from the police power of the state in the manner, and under the circumstances, that Miranda describes, must either be endorsed, modified, or abandoned as a matter of self-reflective interpretation. Other forms of discourse cannot serve as a legitimate point of departure: their "self-evident" truths defeat reasoned debate and totalize the narrative universe on the basis of subjective preferences alone. Covert translation of one dialect into another distorts both, threatens to silence other narrative possibilities, and raises the specter of decisional illegitimacy. Thus, for example, Elstad's putative reliance upon empirical, "pseudo-scientific" observation, as opposed to the dissenters' putative common sense (or "metaphorical" perspective), disguises deeper factual and normative presuppositions. These presuppositions are controversial and warrant debate. The Court's disguise of the normative is a tactic of dialogic dominance.

2) Courts that rely upon cost/benefit analysis as a means of testing 
specific, contextualized interpretations should not confuse this analysis with interpretation itself. To do so threatens to displace interpretive principle with subjectively preferred or unreflectively held presuppositions. This displacement is the risk the Miranda majority took when it activated the crime control lexicon in an effort to accommodate the strict demands of its interpretive principle. It is a move that was exploited later in Harris and Tucker. There, however, the Court's interpretive principle was directly subordinated to a particular, subjectively preferred policy outcome: swift and efficient deterrence based on factual guilt in the service of crime control. This strategic subversion of interpretive principle, like the disengagement of prudence from courage in order to meet common sense expectations, is a strategy of dialogic dominance.

3) Courts may prudently consider the factor of public compliance in reaching decisional outcomes. Controversy, however, cannot realistically be avoided in the judicial decisionmaking process, nor should it be. It is the quality, not the presence, of controversy with which decisionmakers should be concerned. In this respect, the effort manifest in Bram and Tucker to disguise normative preferences by hiding them in the everyday language of common sense, or the similar effort of Malloy to project novel interpretations back into history in order to evade responsibility for explaining and persuasively justifying the Court's own reading of the caselaw, represent strategies of dialogic dominance.

4) Courts should be wary of the unarticulated presuppositions of cost/benefit analysis. To the extent that this "balancing" discourse is used, as in Quarles, the values it advances should be specifically explained and justified. Subjectively preferred values or policy goals should not be smuggled into decisional outcomes in the guise of a putatively "neutral" methodology. Such neutrality belies a strategy of formal dominance.

5) As noted above, the lay public makes a unique contribution to the criminal process. Thus, to the extent that lip service to common sense masks ulterior preferences at the lay public's expense-for example, when common sense is employed to advance crime control ideology-we thereby witness a strategy of formal dominance. Fletcher ${ }^{3}{ }^{402}$ encouragement of a deconstitutionalized state law of confessions and of constitutionally-authorized official promises of benefit or threats of punishment in the context of the plea bargaining process reflects such distortion. Since easing constitutional safeguards increases the risk and unpredictability of trial, it also encourages defendants to seek a more 
certain fate. The ascendancy of the efficient, but wholly privatized and expert-dominated plea bargaining process denies the legitimacy of the public's voice. Indeed, it risks dialogic dominance by a particular expert community that is devoted to subjectively preferred policy preferences. In short, it reflects an overall strategy of formal dominance.

Each of the foregoing examples of dialogic dominance should be condemned and avoided.

By cultivating greater sensitivity to the narrative and normative prejudices built into particular criminal procedure dialects, judicial decisionmakers will be able to make dialogic choices with greater selfconsciousness and with greater awareness of the consequences. In this way, honest persuasion may supplant unwitting or intentional dialogic beguilement and distortion. As a result, increased clarity of reasoning in support of particular outcomes and increased reliance upon crossdialogic reciprocity among diverse dialogic communities may be fostered.

This view of the criminal process reflects a jurisprudence of finitude. Its point of departure is a recognition of the limits inherent in any particular dialogic perspective, a recognition that invites a wider search for narrative possibilities. From this perspective, the decisionmaking process cannot be viewed as a quest for self-evident truths or all-encompassing policies. Born of myriad particular misunderstandings, to which countless legal disputes give witness, its discourse must reflect, and do justice to, the discrete needs and desires and the diverse policy goals and values that give it shape and fuel its motion. In this way, dialogue-even (indeed, especially) across discrete rhetorical fieldsprovides a crucial practical model for the decisionmaking process. It teaches ways of taming strife among incommensurate, but not necessarily incompatible or incomparable, ${ }^{\mathbf{4 0 3}}$ dialects and their corresponding dialogic communities. Put differently, it teaches us to live peaceably amidst the presents that untold narrative possibilities may yet realize.

103 In this context, "incommensurability" means that one dialect cannot always be measured against another point by point. This does not mean, however, that they are "incompatible." Only the two versions of Scientific Policymaking are incompatible in this sense (i.e., the utilitarian and Kantian points of departure embody genuinely conflicting fundamental principles or axioms). Nor does it mean that the three dialects of criminal procedure are "incomparable." Indeed, it is the raison d'être of this Article to suggest constructive ways in which all three criminal procedure dialects may (and should) be compared in order to maximize their respective virtues and minimize their vices. Cf. R. BERNSTEIN, supra note 10, at 86-93 (discussing incommensurability in the context of rival scientific paradigms). 


\section{CoNCLUSION}

Dialogic dominance in the law of confessions has taken different forms during different historical periods. It has shifted from the unreflective and conflicting, putatively "self-evident" truths of common sense, to self-reflective, at least debatably prudent interpretation of inherited texts, to self-reflective, systematically deployed policy commitments.

As the official language of power has shifted, the way in which self, other, and social institutions came to be understood has correspondingly changed. Narrative and normative accounts that made sense (or failed to) have done so on the basis of presuppositions built into the structure of the ascendant dialect. Shifts in dialogic dominance have also engendered changes in the distribution of power in society. The ascendancy of a particular criminal procedure dialect carries with it the ascendancy of that dialect's corresponding dialogic community. Thus, we have seen the common sense of the lay public increasingly displaced by special expertise: initially, the judicial expertise of contextualized interpretation (of inherited texts and institutions) and, subsequently, the extrajudicial expertise of systematic (cost/benefit) social policy talk.

Dialogic dominance, however, does more than shape narrative coherence and affect the distribution of power in society. It also presses toward tyranny: the tyranny of dialogic exclusion and the imposed silence that such exclusion fosters. As a particular dialect gains ascendancy, alternative ways of thinking and speaking either become nonsensical ("incoherent") and irrelevant to the ruling discourse, or are captured and reformed by the dominant dialect through a process of systematic "translation." Familiar words and texts lose their old meanings. The appearance of continuity belies a thorough reconstruction of narrative reality; the possibilities of meaning are closed down.

The form of tyranny that a particular, dominant dialect will take corresponds to its discrete defects. For example, because ordinary common sense lacks reflection, its "self-evident" truths characterize reality in inconsistent and unpredictable ways. This is the majoritarian tyranny: muddled, unruly, readily unmindful of counter-intuitive (textual or institutional) principles or comprehensive social policies. Because prudent interpretation takes specific, concrete conflicts as its point of departure, its contextualized interpretations risk, on the one hand, unpredictability and the appearance of discontinuous and unregulable standards. On the other hand, its awareness of this danger breeds strategic devices that threaten to unravel its own principled framework. This is the interpretive countermajoritarian tyranny: constantly caught 
in a tense and uncertain compromise between principle and compliance. Because scientific policymaking takes its point of departure from particular "self-evident" axioms or principles, like ordinary common sense, it totalizes truth. However, because, unlike common sense, it is reflective, its totalization is systematic and invariable. This is the countermajoritarian tyranny of a preferred (comprehensive) policy: ever willing to conform reality, and in some instances even to sacrifice the particular needs and desires of parties in a concrete controversy, to the rigid demands of "self-evidently" preferable comprehensive and selfconsistent principles or ends.

It is the latter tyranny, manifest in the exclusive demands of crime control ideology, that seems to characterize the federal judiciary's current work in the law of confessions.

This Article has sketched the ramifications of dialogic dominance so that the threat of a discrete form of tyranny, and of its delegitimation of the judicial decisionmaking process, may be checked, if not on the federal level, at least among state courts. The Supreme Court's new federalism has made several forms of tyranny possible by largely removing the federal courts from constitutional adjudication in state confessions law. This action consequently increases the responsibilities that state courts must bear for giving shape and content to the nomos of our legal culture.

The proposed antidote to tyranny in the area of law that this Article addresses is the intrajudicial institution of checks and balances among the three dialects of criminal procedure. This Article contends that the unique virtues of a particular dialect may be used to check the defects inherent in other ways of thinking and communicating. Further, the inability of each dialect to constrain its own tendency toward tyranny (i.e., the disempowerment of other dialogic modes and their corresponding communities) fosters the need to balance its discrete virtues against those of other criminal procedure dialects. In this way, the role of lay publics and legal experts may be preserved intact. In addition, by ensuring cross-dialectical reciprocity among incommensurate, but not incomparable or incompatible, dialogic communities, the ideal to which our liberal democracy aspires remains vital. That ideal is manifest in the practice of "communication as colloquy"-the dialogic process by which narrative possibilities come to be intersubjectively shared. It is by this process that human understanding achieves an embodied existence in our world. 
